\title{
Formazanate Complexes of Bis-Cyclometalated Iridium
}

\author{
Evanta Kabir, Ge Mu, David A. Momtaz, Noah A. Bryce, Thomas Teets
}

Submitted date: 03/06/2019 Posted date: 04/06/2019

Licence: CC BY-NC-ND 4.0

Citation information: Kabir, Evanta; Mu, Ge; Momtaz, David A.; Bryce, Noah A.; Teets, Thomas (2019):

Formazanate Complexes of Bis-Cyclometalated Iridium. ChemRxiv. Preprint.

In this work we describe a series of bis-cyclometalated iridium(III) formazanate complexes, expanding the coordination chemistry of the redox-active formazanate class to iridium. A total of 18 new complexes are described, varying the substituent pattern on the formazanate and the identity of the cyclometalating ligand on iridium. Eight of the new compounds are structurally characterized by single-crystal X-ray diffraction, which along with NMR spectroscopy evinces two binding modes of the formazanate. Two of the compounds are isolated in a C2-symmetric geometry where the formazanate is bound in a six-member chelate "closed" conformation, involving the 1- and 5-positions of the 1,2,4,5-tetraazapentadienyl formazanate core. In most of the examples, the major isomer that forms and is exclusively isolated involves the formazanate bound in a five-member chelate "open" form, coordinating through the 1- and 4-positions of the formazanate core and resulting in $\mathrm{C} 1$ point-group symmetry. All complexes are characterized by UV-vis absorption spectroscopy and cyclic voltammetry, with these features depending primarily on the substitution pattern on the formazanate, and to a lesser extent on the identity of the cyclometalating ligand and formazanate binding mode.

File list (2)

Ir $\mathrm{C}^{\wedge} \mathrm{N}$ formazanate text.pdf (842.67 KiB)

view on ChemRxiv • download file

Ir $\mathrm{C}^{\wedge} \mathrm{N}$ formazanate SI.pdf (6.86 MiB)

view on ChemRxiv • download file 


\title{
Formazanate Complexes of Bis-Cyclometalated Iridium
}

\author{
Evanta Kabir, $\stackrel{\ddagger}{\ddagger}$ Ge Mu, ${ }^{\ddagger}$ David A. Momtaz, Noah A. Bryce, and Thomas S. Teets* \\ University of Houston, Department of Chemistry, 3585 Cullen Blvd. Room 112, Houston, TX USA 77204-5003
}

\begin{abstract}
In this work we describe a series of bis-cyclometalated iridium(III) formazanate complexes, expanding the coordination chemistry of the redox-active formazanate class to iridium. A total of 18 new complexes are described, varying the substituent pattern on the formazanate and the identity of the cyclometalating ligand on iridium. Eight of the new compounds are structurally characterized by single-crystal Xray diffraction, which along with NMR spectroscopy evinces two binding modes of the formazanate. Two of the compounds are isolated in a $C_{2}$-symmetric geometry where the formazanate is bound in a six-member chelate "closed" conformation, involving the 1-and 5-positions of the 1,2,4,5-tetraazapentadienyl formazanate core. In most of the examples, the major isomer that forms and is exclusively isolated involves the formazanate bound in a five-member chelate "open" form, coordinating through the 1- and 4-positions of the formazanate core and resulting in $C_{1}$ point-group symmetry. All complexes are characterized by UV-vis absorption spectroscopy and cyclic voltammetry, with these features depending primarily on the substitution pattern on the formazanate, and to a lesser extent on the identity of the cyclometalating ligand and formazanate binding mode.
\end{abstract}

\section{INTRODUCTION}

The coordination chemistry of formazans, which are a class of chromophoric conjugated organic molecules with a 1,2,4,5-tetraazapentadienyl core, has long been investigated with transition metals and main group metals. The nitrogen-rich redox active formazans have also been intensively studied in the fields of bioinorganic chemistry ${ }^{1,2}$ and catalysis ${ }^{3-5}$, and a few successful applications have emerged over time in biomedical assays, textile dyes, and colorimetric indicators of cell activity. ${ }^{6-9}$ The monoanionic form of formazans (referred to as "formazanates") have become a well-known $N$-chelating ligand class in recent years, structurally analogous to the ubiquitous $\beta$-diketiminate ligand class but with redox activity at much more accessible potentials and strong visible absorption, primarily because of LUMOs that are significantly stabilized relative to $\beta$-diketiminates. ${ }^{10-13}$ The growing interest in formazanate coordination complexes is largely due to the ligand-based redox processes, which can facilitate multielectron redox behavior, ${ }^{14}$ bond activation, ${ }^{15}$ and excited-state charge separation. In particular, the stabilized LUMOs in formazanates result in relatively stable reduced products, greatly expanding the redox chemistry of these complexes in small-molecule activation and other contexts. ${ }^{16-18}$

Complexes of first-row transition metals with formazanates have been extensively reported, ${ }^{5,19}$ including copper complexes which mediate oxygen activation. ${ }^{20,21}$ The ligand-based redox chemistry of low-coordinated iron complexes ${ }^{22-24}$ and bis-chelated zinc complexes $^{25,26}$ has recently been characterized. Unique magnetic properties were demonstrated in heteroleptic cobalt and bis(formazanate) iron complexes. ${ }^{27-29}$ Formazanate complexes of group $14 \mathrm{el}-$ ements and ruthenium highlight the redox non-innocence of some classes of formazanate complexes. ${ }^{16,30}$ Furthermore, boron chelates of formazanates not only exhibit tunable redox properties but are also in many cases photoluminescent, ${ }^{31-36}$ finding applications as cell-imaging agents, ${ }^{33,37}$ electrochemiluminescence emitters, ${ }^{38,39}$ multifunctional polymers, ${ }^{40,41}$ and precursors to a wide range of $\mathrm{BN}$ heterocycles. $^{42,43}$
In spite of these numerous examples, coordination complexes of formazans with third-row transition metals remain rare. Dithizonate complexes with a formazan-like core were described where coordination of sulfur to the metal was observed. ${ }^{44}$ Complexes of dianionic aryl formazanate ligands which involve o-phenoxy or o-benzoate donors were found to be coordinated in a tridentate fashion with a few heavy transition metals, but none of them were extensively characterized or analyzed for further studies. ${ }^{45-48}$ Since the strong orbital overlap between radially extended $5 \mathrm{~d}$ orbitals and the formazanate $\pi$ system could perturb the inherent redox and optical properties of the formazanates and the $5 \mathrm{~d}$ metal center could promote formazanate-centered triplet photophysics, our group began investigating third-row transition metal complexes of formazanates. We have expanded the coordination chemistry of formazanates a series of heteroleptic platinum complexes ${ }^{49,50}$ and accessed homoleptic azo-iminate platinum complexes ${ }^{51}$ via hydrogenative cleavage of formazans.

In this work, we describe a diverse set of cyclometalated iridium(III) formazanate complexes. Cyclometalated iridium(III) compounds have been extensively studied in a number of contexts, ${ }^{52-57}$ primarily due to their good thermal and photostability, relatively short phosphorescence lifetime, and high photoluminescence quantum yields. Although the synthetic chemistry of cyclometalated iridium(III) formazanates largely parallels that of our previous cyclometalated platinum(II) formazanate series, ${ }^{49,50}$ moving from platinum(II) to iridium(III) allows us evaluate the effects of coordination geometry and d-electron count on the structural chemistry, redox properties, and optical properties of $5 \mathrm{~d}$ metal formazanates. We describe $18 \mathrm{new}$ cyclometalated iridium(III) formazanate complexes of the type $\operatorname{Ir}\left(C^{\wedge} N\right)_{2}$ (formazanate) ( $C^{\wedge} N=$ cyclometalating ligands). These neutral complexes feature four different cyclometalating ligands and six structurally and electronically varied triaryl- and diarylformazanates. A general synthetic route is presented here, and 8 of $18 \mathrm{com}$ pounds are structurally characterized by single crystal X-ray diffrac- 
tion, which reveals two distinct coordination modes for the formazanate. The substitution patterns on the formazanate strongly influence the observed ligand-centered redox potentials, with subtle influences from the $\mathrm{C}^{\wedge} \mathrm{N}$ ligand that suggest some degree of mixing between iridium d-orbitals and formazanate $\pi$ orbitals. The UV-vis absorption spectra show intense bands from the contributions of both formazanates and $\operatorname{Ir}-\mathrm{C}^{\wedge} \mathrm{N}$ fragments, and solvatochromic studies assist in the assignment of these features. This work demonstrates that alteration of the $\mathrm{C}^{\wedge} \mathrm{N}$ and formazanate ligands offers two layers of control over the redox and optical properties of neutral iridium formazanate complexes.

\section{RESULTS AND DISCUSSION}

Synthesis. Scheme 1 depicts the general synthetic procedure of the series of 18 heteroleptic cyclometalated iridium formazanate complexes of the type $\operatorname{Ir}\left(\mathrm{C}^{\wedge} \mathrm{N}\right)_{2}$ (formazanate). Compounds are numbered based on the identity of the $\mathrm{C}^{\wedge} \mathrm{N}$ ligand, with the associated letter designating the structure of the formazanate ancillary ligand. Two cyclometalating ligands, 2-phenylpyridine (ppy) and 2-(2,4difluorophenyl)pyridine ( $F_{2}$ ppy), are partnered with all six formazanates studied here (Fza-Fzf), to produce products $\mathbf{1 a - 1 f}$ and $\mathbf{2 a -}$ 2f, while the other two $\mathrm{C}^{\wedge} \mathrm{N}$ ligands, 2-phenylbenzothiazole (bt) and 1-phenylisoquinoline(piq), are used to prepare a smaller subset of complexes (3a, 3b, 3e, 3f, $4 a$, and $4 f$ ). The chloro-bridged dimers $\left[\operatorname{Ir}\left(C^{\wedge} N\right)_{2}(\mu-C l)\right]_{2}$ are treated with a stoichiometric amount of free formazan in ethanol in the presence of excess triethylamine, by refluxing for 20-36 hours. The reaction is general and tolerates a variety of electronically modified formazans, which include different combinations of electron-donating $\left(-\mathrm{CH}_{3},-\mathrm{OCH}_{3}\right)$ and electronwithdrawing $(-\mathrm{CN})$ substituents at either the azo aryl substituent $\left(\mathrm{R}^{1}\right)$ or at the central position of the backbone $\left(\mathrm{R}^{2}\right)$. Reactions involving triarylformazanates $(\mathrm{Fza}-\mathrm{d})$ showed a distinct color change from purple (free formazan) to dark green or blue upon coordination of the formazanate to iridium. In contrast, in reactions involving diarylformazanates, the color of the product is almost identical to the free formazan, and these are most conveniently monitored by TLC. The isolated yields vary from $43-80 \%$ across the series.

NMR analysis of crude reaction mixtures indicates the possibility of two isomeric products. In particular, some of the complexes with electron-donating substituents on the formazanate, $1 \mathrm{a}, 1 \mathrm{~b}, 3 \mathrm{a}$, $3 \mathrm{~b}$, and $4 \mathrm{a}$, as well as $1 \mathrm{c}\left(\mathrm{R}^{2}=p-\mathrm{C}_{6} \mathrm{H}_{4}-\mathrm{CN}\right)$, initially showed the presence of two products in their ${ }^{1} \mathrm{H}$ NMR spectra, one with apparent $C_{2}$ symmetry and one with $C_{1}$ symmetry. As unequivocally determined by X-ray crystallography (see below), these features are attributed to two different binding modes of the formazanate, one that involves a five-member chelate ring "open" form, binding through the 1-and 4-positions of the formazanate core, and the other a more typical six-member chelate "closed" form, binding through the 1and 5-positions and denoted by a prime symbol (') in the compound numbering scheme. Varying the reaction solvents (dichloromethane, tetrahydrofuran) and temperature did not significantly alter the isomeric ratio, and prolonged heating of isolated mixtures of isomers did not lead to significant interconversion. Chromatographic purification was not effective as both isomers are similar in polarity. Recrystallization of the above-mentioned products was generally a good approach for purifying the mixtures, allowing $3 \mathrm{a}$, $3 \mathrm{~b}$, and $4 \mathrm{a}$ to be isolated as the $C_{1}$-symmetric "open" form with only trace amount of the "closed" isomer present. In contrast, in the $\mathrm{C}^{\wedge} \mathrm{N}$
$=$ ppy series recrystallization allowed isolation of $1 \mathbf{b}^{\prime}$ and $1 \mathbf{c}^{\prime}$ exclusively as the $C_{2}$-symmetric "closed" isomer, whereas $1 \mathrm{a} / 1 \mathrm{a}$ ' was isolated as a mixture of isomers even after repeated recrystallization attempts. The remaining triarylformazanate iridium complexes were all isolated in the five-member chelate conformation, as were all diarylformazanate complexes prepared from Fze and Fzf. To summarize, 15 of the 18 complexes were isolated in pure form as the fivemember chelate "open" form, whereas only $1 \mathbf{b}^{\prime}$ and $1 \mathbf{c}^{\prime}$ were obtained in the "closed" form and 1a was isolated as a mixture of both isomers. All of the compounds are air and moisture stable and are fully characterized by ${ }^{1} \mathrm{H},{ }^{13} \mathrm{C}\left\{{ }^{1} \mathrm{H}\right\}$, and ${ }^{19} \mathrm{~F}$ (for $2 \mathrm{a}-2 \mathrm{f}$ ) NMR spectroscopy and elemental analysis, which establish identity and bulk purity. NMR spectroscopy is especially useful for distinguishing the two isomers, with the $C_{2}$-symmetric "closed" isomer displaying chemical equivalency of the $C^{\wedge} N$ ligands and the two $R^{1}$ substituents on the formazanate.

Scheme 1. General synthesis of complexes 1-4.

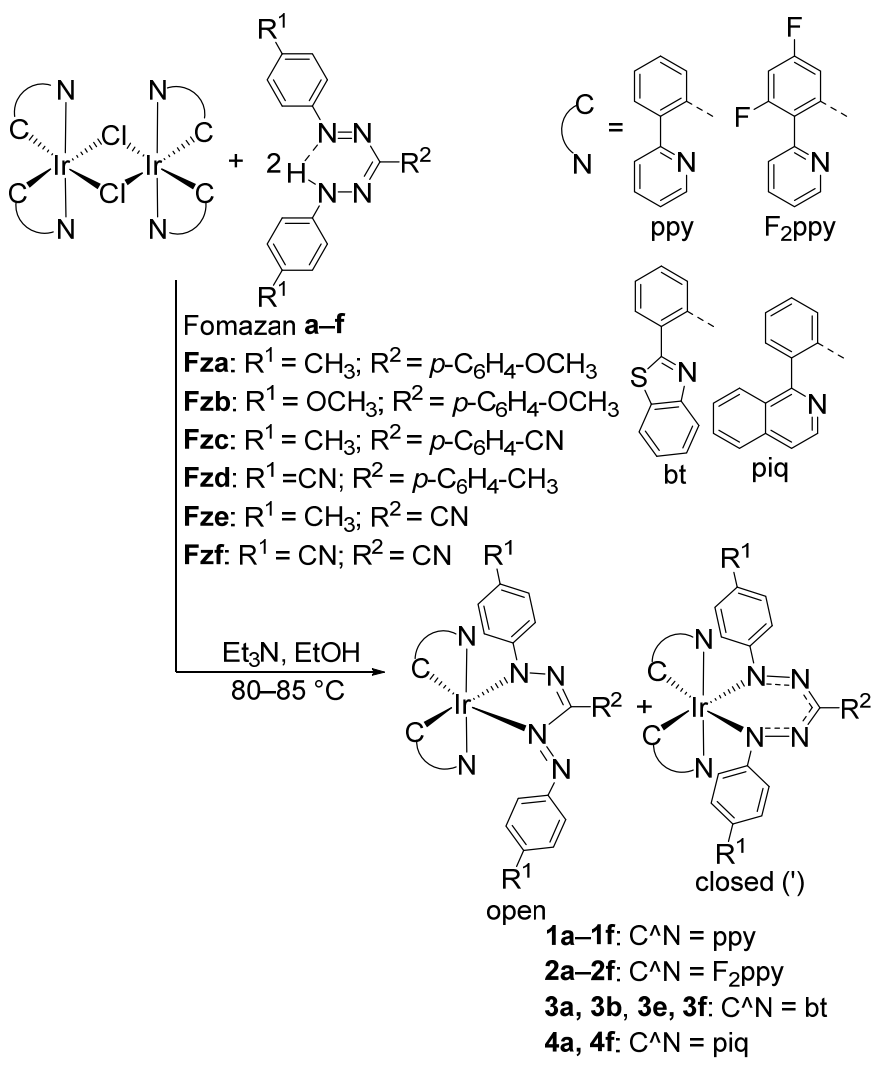

X-ray Crystallography. The structures of $1 c^{\prime}, 1 d, 2 a, 2 c, 2 c^{\prime}, 2 d$, $2 \mathrm{e}, 3 \mathrm{a}$, and $4 \mathrm{a}$ were confirmed by single-crystal $\mathrm{X}$-ray diffraction, are shown in Figure 1 and Figure S1. Formazanate bond lengths and angles are summarized in Table 1 with refinement details collected in Tables S2-S4. The iridium metal center resides in the center of distorted octahedral coordination geometry with two $\mathrm{C}^{\wedge} \mathrm{N}$ ligands and one formazanate. In all cases, the nitrogen atoms of $\mathrm{C}^{\wedge} \mathrm{N}$ ligands are in a trans position relative to each other. The $\mathrm{Ir}-\mathrm{C}$ bond distances (2.014(7)-2.033(4) $\AA$ ) and Ir-N bond distances involving the $\mathrm{C}^{\wedge} \mathrm{N}$ ligands $(2.036(17)-2.091(8) \AA$ ) of all complexes are similar to those of the previously reported cyclometalated Ir complexes. ${ }^{52,54} \mathrm{Com}$ plex $1 c^{\prime}$ crystallized with the formazanate exclusively in the six-membered chelate "closed" form, whereas in $2 \mathrm{c}$ both isomers were present, modeled as a two-part disorder with $71 \%$ of the "open” form 


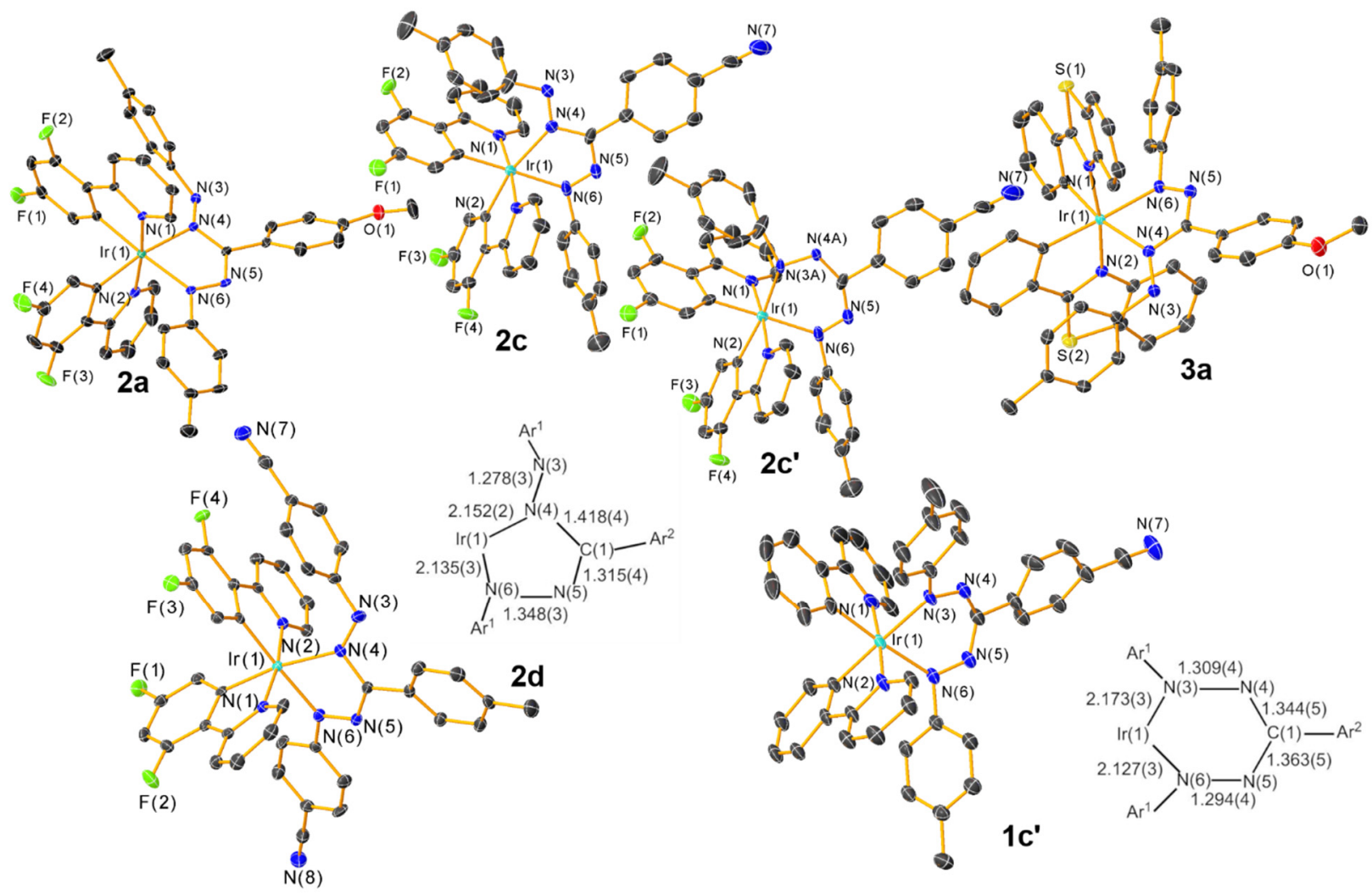

Figure 1. X-ray crystal structure of complexes $1 c^{\prime}, 2 \mathrm{a}, 2 \mathrm{c}$ ("open”), $2 \mathrm{c}^{\prime}$ ("closed”), $2 \mathrm{~d}$, and 3a, with ellipsoids shown at the $50 \%$ probability level and hydrogen atoms omitted. To better visualize the geometric differences between the "open” and "closed” forms, the bottom stick diagrams show bond lengths of $2 \mathrm{~d}$ and $1 \mathrm{c}^{\prime}$ in $\AA$, with esd values in parentheses.

Table 1. Summary of crystallographic bond lengths $(\AA)$ and angles (deg).

\begin{tabular}{llllllllll}
\hline & $1 \mathrm{c}^{\prime}$ & $1 \mathrm{~d}$ & $2 \mathrm{a}^{\mathrm{a}}$ & $2 \mathrm{c}^{\mathrm{b}}$ & $2 \mathrm{c}^{\mathrm{b}}$ & $2 \mathrm{~d}$ & $2 \mathrm{e}$ & $3 \mathrm{a}$ & $4 \mathrm{a}$ \\
\hline $\mathrm{d}(\mathrm{Ir}-\mathrm{N} 3 / 4)^{\mathrm{c}}$ & $2.173(3)$ & $2.208(8)$ & $2.161(4)$ & $2.210(5)$ & $2.142(9)$ & $2.152(2)$ & $2.155(6)$ & $2.1545(18)$ & $2.192(3)$ \\
$\mathrm{d}(\mathrm{Ir}-\mathrm{N} 6)$ & $2.127(3)$ & $2.119(8)$ & $2.125(4)$ & $2.110(3)$ & $2.110(3)$ & $2.135(3)$ & $2.103(7)$ & $2.1234(17)$ & $2.153(3)$ \\
$\mathrm{d}(\mathrm{N} 3-\mathrm{N} 4)$ & $1.309(4)$ & $1.318(11)$ & $1.313(5)$ & $1.285(7)$ & $1.325(12)$ & $1.278(3)$ & $1.263(11)$ & $1.292(2)$ & $1.309(5)$ \\
$\mathrm{d}(\mathrm{N} 4-\mathrm{C} 1)$ & $1.344(5)$ & $1.376(12)$ & $1.383(5)$ & $1.400(6)$ & $1.418(10)$ & $1.418(4)$ & $1.397(11)$ & $1.404(3)$ & $1.378(5)$ \\
$\mathrm{d}(\mathrm{N} 5-\mathrm{C} 1)$ & $1.363(5)$ & $1.333(12)$ & $1.328(6)$ & $1.349(5)$ & $1.349(5)$ & $1.315(4)$ & $1.314(12)$ & $1.332(3)$ & $1.330(6)$ \\
$\mathrm{d}(\mathrm{N} 5-\mathrm{N} 6)$ & $1.294(4)$ & $1.314(11)$ & $1.313(5)$ & $1.297(4)$ & $1.297(4)$ & $1.348(3)$ & $1.304(8)$ & $1.322(2)$ & $1.322(5)$ \\
$\angle \mathrm{N}(3 / 4)-\mathrm{Ir}-\mathrm{N}(6)^{\mathrm{d}}$ & $82.45(11)$ & $74.1(3)$ & $74.53(14)$ & $70.50(15)$ & $94.5(3)$ & $74.45(9)$ & $75.6(3)$ & $73.88(7)$ & $73.62(13)$ \\
\hline
\end{tabular}

${ }^{a}$ Average of two crystallographically independent molecules. ${ }^{b}$ Both isomers disordered in the same crystal structure. ${ }^{c}$ Formazanate Ir-N distance. Relevant distance is Ir-N3 for "closed" isomers $1 c^{\prime}$ and $2 c^{\prime}$, and Ir-N4 for the rest. ${ }^{d}$ Formazanate N-Ir-N chelate angle. Relevant angle is $\angle \mathrm{N}(3)-\mathrm{Ir}-$ $\mathrm{N}(6)$ for "closed" isomers $1 \mathrm{c}^{\prime}$ and $2 \mathrm{c}^{\prime}$, and $\angle \mathrm{N}(4)-\mathrm{Ir}-\mathrm{N}(6)$ for the rest.

(2c) and $29 \%$ of the "closed" form $\left(2 c^{\prime}\right)$. As shown in Table 1 and Figure 1, the binding mode of the formazanate ("open" vs. "closed") has little influence on the $\mathrm{Ir}-\mathrm{N}$ (formazanate) bond distances, which range between 2.103(7) and 2.210(5) $\AA$ and are significantly longer than those in other formazanate chelate complexes (1.809-2.090 A). ${ }^{16,25,26,28,49,50,58}$ The different chelating modes of formazanates, however, impact the bond distances within the formazanate core critically. For both cases of $1 \mathbf{c}^{\prime}$ and $2 \mathbf{c}^{\prime}$, which include the "closed" form of the formazanate, full $\pi$ delocalization within the formazanate is indicated. The two $\mathrm{N}-\mathrm{N}$ and two $\mathrm{N}-\mathrm{C}$ distances are nearly equal and intermediate between single and double bonds. In contrast, for "open form" formazanate chelating complexes, in many cases there are alternating short and long bond distances in the formazanate core, which is particularly apparent in the structures of $2 \mathrm{~d}, 2 \mathrm{e}, 3 \mathrm{a}$, and $4 \mathrm{a}$. In these cases, the $\mathrm{N}(3)-\mathrm{N}(4)$ distances exterior to the fivemember chelate ring are shorter than the $\mathrm{N}(5)-\mathrm{N}(6)$ distances in the chelate ring, and the $\mathrm{N}(4)-\mathrm{C}(1)$ distance is significantly longer than $\mathrm{N}(5)-\mathrm{C}(1)$. This pattern of bond distances is consistent with less $\pi$ delocalization in the "open" form, which in the localized limit consists of alternating single and double bonds, as shown in the structure diagram in Scheme 1. Unsurprisingly, the other major structural difference between the "open" and "closed" forms is the 

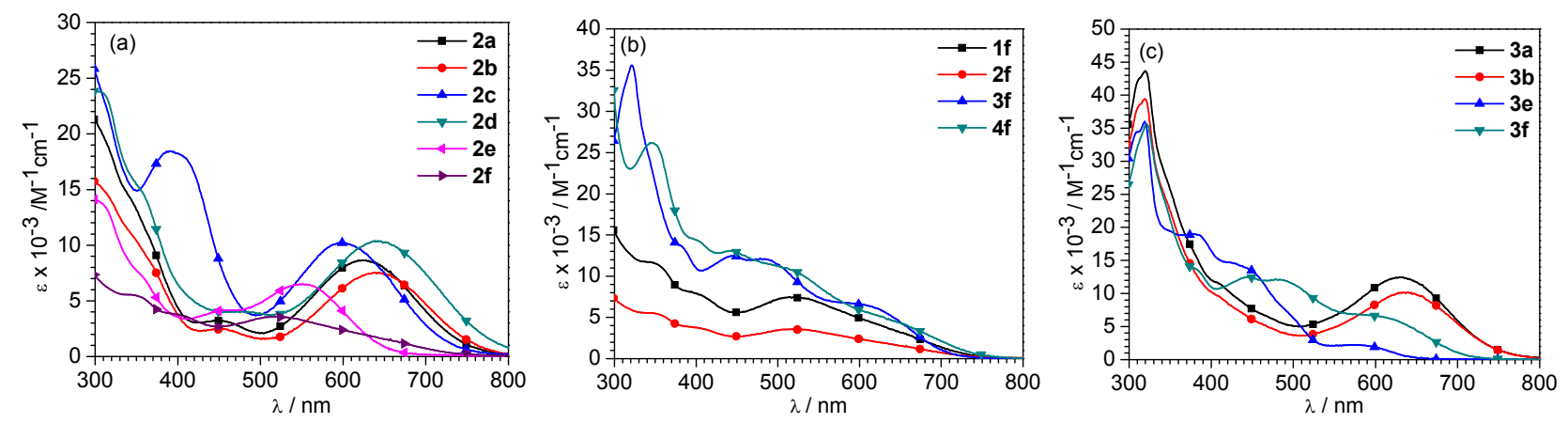

Figure 2. Overlaid electronic absorption spectra of (a) 2a-2f, (b) 1f-4f, and (c) 3a, 3b, 3e, and 3f. Spectra were recorded in tetrahydrofuran (THF) solution in room temperature. Data was collected in intervals of $1 \mathrm{~nm}$, and symbols are included on each plot are to help distinguish the overlaid spectra.

chelate angles of formazanates, which for the "open" forms range between $74.10(3)$ and $74.45(9)^{\circ}(\angle \mathrm{N}(4)-\mathrm{Ir}-\mathrm{N}(6))$, except $2 \mathrm{c}$ which has an abnormally small chelate angle $\left(70.50(15)^{\circ}\right)$. The formazanate bite angles are larger for the $C_{2}$-symmetric isomers, observed to be $82.45(11)^{\circ}$ in $1 c$ and $94.5(3)^{\circ}$ in $2 c^{\prime}$. There does not appear to be any systematic dependence of the key structural metrics on the presence of electron-withdrawing or electron-donating groups on the formazanate periphery.

The observation of both structure types ("open" and "closed") suggests that the two structures are similar in free energy, though overall the "open" isomer seems to be favored. This observation stands in contrast to many previously described platinum(II) formazanates, where only the "closed" binding mode was observed. ${ }^{49,50}$ The covalent radii of platinum and iridium are quite similar, ${ }^{59}$ so we don't think the preference for a five-member chelate is because iridium(III) is smaller than platinum(II), nor are there any obvious electronic differences between the two isomers (see description of UVvis and electrochemistry below). We propose that the "open" binding mode relieves steric pressure in these complexes, avoiding close approaches of the formazanate $N$-aryl substituent with the aryl rings of the cyclometalating ligand. In previously characterized bis-cyclometalated iridium $\beta$-diketiminate complexes from our group, we noted a close stacking arrangement of the $N$-aryl groups and the cyclometalated aryl groups, ${ }^{60,61}$ which is avoided in $1 c^{\prime}$ ("closed" isomer) by a buckling of the formazanate backbone. In contrast, in all of the "open"-form structures presented here, except in $2 \mathrm{c}$ where the two isomers are disordered, the aryl substituent at the iridiumbound $\mathrm{N}(6)$ is safely away from the steric congestion of the cyclometalating ligands, oriented orthogonal to the nearest cyclometalated aryl ring in a cleft between the two $\mathrm{C}^{\wedge} \mathrm{N}$ ligands. Thus, the crystallographic evidence suggests that it is steric effects that are likely responsible for the "open" chelate conformation most of these complexes adopt.

UV-vis Absorption Spectroscopy. UV-vis absorption spectra of all cyclometalated iridium formazanate complexes were recorded, and Table 2 represents the summarized absorption data in tetrahydrofuran (THF). Figure 2 displays spectra of the complexes $2 a-2 f, 1 f-4 f$, and $3 a, 3 b, 3 e$, and $3 f$. UV-vis absorption spectra of the remaining complexes in THF are shown in Figures S44 and S45. None of the complexes are photoluminescent in the visible region at room temperature or $77 \mathrm{~K}$. All of the complexes described here are highly colored, appearing green or bluish green for the triarylformazanate complexes and greenish brown to dark red for the diarylformazanates complexes. These iridium formazanate compounds display low-energy absorption bands between 525-677 $\mathrm{nm}$ with extinction coefficients between $2200-13000 \mathrm{M}^{-1} \mathrm{~cm}^{-1}$ in the visible range of the spectrum, which is assigned as a formazanate ligand-centered $\pi \rightarrow \pi^{*}$ transition primarily involving HOMO and LUMO orbitals. As shown in Table 2 these low-energy absorption maxima are nearly identical for all of the triarylformazanate complexes $1 a / 1 b, 2 a / 2 b$, $3 a / 3 b$ and $4 a$, ranging from $628-639 \mathrm{~nm}$ for these complexes which have electron-donating substituents at both the $\mathrm{R}^{1}$ and $\mathrm{R}^{2}$ position of the formazanate scaffold (Figures 2, S44, and S45). Complex 1a is isolated as a mixture of "open" and "closed" isomers but no significant spectral differences are observed by comparing this with the other Fza complexes that exist exclusively in the "open" configuration. The position of the low-energy absorption band depends strongly on the identity of the substituents at the central $\mathrm{R}^{2}$ position of the formazanate backbone. Placing the electron withdrawing 4cyanophenyl group in the $\mathrm{R}^{2}$ position (Fzc) causes a hypsochromic shift of $\sim 27-38 \mathrm{~nm}\left(715-989 \mathrm{~cm}^{-1}\right)$ in the low-energy absorption maximum for complexes $1 \mathbf{c}^{\prime}$ and $2 \mathrm{c}$ relative to the respective $\mathbf{F z a}$ and Fzb complexes. In contrast, this low-energy absorption band is red-shifted for complexes $1 \mathrm{~d}(677 \mathrm{~nm})$ and $2 \mathrm{~d}(655 \mathrm{~nm})$, when the 4-cyanophenyl substituent is on the formazanate nitrogen atoms, i.e. $\mathrm{R}^{1}=\mathrm{CN}$. As shown in Table 2, replacing the aryl group at the $\mathrm{R}^{2}$ position with a cyano group in diarylformazanate (Fze and Fzf) complexes results in a significant blue-shift, with the low-energy absorption maximum occurring between $520 \mathrm{~nm}$ (1f) and $578 \mathrm{~nm}(3 \mathrm{e})$ in this subset of complexes. This significant blue-shift in the formazanate $\pi \rightarrow \pi^{*}$ transition is likely a result of the decreased conjugation in the diarylformazanate analogues.

Additionally, higher-energy absorption bands are observed in the near-UV and visible regions, dependent primarily on the identity of the cyclometalated ligands, characteristic of $\operatorname{Ir}(d) \rightarrow \pi^{*}$ metal-to-ligand charge transfer (MLCT) bands and only slightly affected by the $N$-aryl substituents of the formazanate ligands. These bands typically overlap with other high-energy absorption features, likely localized $\pi \rightarrow \pi^{*}$ transitions, though in general $F_{2}$ ppy-ligated complexes 2a-f display MLCT bands at the shortest wavelengths, with piq complexes (4a and 4f) having MLCT bands at the longest wavelength, consistent with many other cyclometalated iridium complexes. ${ }^{62}$ Complexes of Fzc $\left(\mathrm{R}^{2}=4\right.$-cyanophenyl $)$ display a distinct absorption at $\sim 400 \mathrm{~nm}$, which is not observed in other members of the series and is likely attributed to a transition localized on the 4cyanophenyl substituent. In many complexes, particularly in the bt (3, Figure 2c) and piq series (4, Figure S45), the high-energy absorption features overlap with low-energy formazanate-centered 
bands, giving rise to panchromatic visible absorption, as observed for previously reported cyclometalated platinum formazanate compounds with $\mathrm{C}^{\wedge} \mathrm{N}=2$-phenylquinoline (pq), an isomer of piq. ${ }^{50}$

Table 2. Summary of UV-vis absorption data recorded in tetrahydrofuran (THF) at room temperature.

\begin{tabular}{|c|c|}
\hline & $\lambda / \mathrm{nm}\left(\varepsilon \times 10^{-3} / \mathrm{M}^{-1} \mathrm{~cm}^{-1}\right)$ \\
\hline $1 \mathrm{a} / 1 \mathrm{a}$ & $265(53), 480(6.7), 633(13)$ \\
\hline $1 b^{\prime}$ & $261(25), 463(3.6), 630(3.2)$ \\
\hline $1 c^{\prime}$ & $264(71), 387(42), 602(8.7)$ \\
\hline $1 d$ & $270(17), 370^{a}(6.8), 677(4.6)$ \\
\hline 1e & $260(30), 380^{\mathrm{a}}(8.0), 476(5.8), 554(6.6)$ \\
\hline If & $258(33), 342(10), 401^{\mathrm{a}}(7.9), 520(7.5)$ \\
\hline $2 a$ & $250(34), 347^{\mathrm{a}}(13), 445(3.2), 628(8.6)$ \\
\hline $2 b$ & $252(27), 454(2.9), 639(7.5)$ \\
\hline $2 c$ & $251(52), 390(18), 601(10)$ \\
\hline $2 d$ & $260 \mathrm{a}(38), 313^{\mathrm{a}}(23), 360^{\mathrm{a}}(17), 655(10)$ \\
\hline $2 \mathrm{e}$ & $250(28), 300(14), 454^{a}(4.2), 551(6.5)$ \\
\hline $2 f$ & $261(15), 353^{\mathrm{a}}(5.4), 532(3.5)$ \\
\hline $3 a$ & $320(43), 410^{\mathrm{a}}(11), 630(12)$ \\
\hline $3 b$ & $262(36), 319(39), 635(10)$ \\
\hline $3 e$ & $263(34), 319(36), 382^{a}(18), 443^{a}(14), 578(2.2)$ \\
\hline $3 \mathrm{f}$ & $266(38), 321(36), 384^{a}(13), 443(12), 596(6.7)$ \\
\hline $4 a$ & $293(51), 349^{\mathrm{a}}(29), 435^{\mathrm{a}}(9.0), 638(9.4)$ \\
\hline $4 f$ & $285(44), 343(26), 403(14), 443(13), 525^{\mathrm{a}}(10)$ \\
\hline
\end{tabular}

${ }^{\text {a }}$ Shoulder.

UV-vis spectra were also recorded in three solvents of varying polarity (toluene, THF, and $\mathrm{MeOH}$ ), shown in Figures S46-S48, and only slight solvatochromic shifts of $<10 \mathrm{~nm}$ were observed for the low-energy absorption bands in all cyclometalated iridium formazanate complexes, further supporting the assignment of this band as a ligand-localized $\pi \rightarrow \pi^{*}$ transition with minimal charge-transfer character. Taken together, these results show that the UV-vis absorption features of the iridium formazanate complexes depend on the location and identity of the substituents on the formazan scaffold as well as the cyclometalating ligand. Changing substituents at the $\mathrm{R}^{1}$ and $\mathrm{R}^{2}$ position of the formazanate ligand allows predictive control over the formazanate-based low energy $\pi \rightarrow \pi^{*}$ transition, which spans a relatively broad range of 520-677 $\mathrm{nm}$ in this series of complexes.

Electrochemistry. The electrochemical properties of complexes 14 were investigated by cyclic voltammetry $(\mathrm{CV})$ experiments, and the results are summarized in Table 3 with the voltammograms shown in Figures 3 and S49-S51. The compounds display both oxi- dation and reduction features in their cyclic voltammograms. Ligand-centered reductions that occur at mild potential are generally one of the most important features of coordinated formazanate complexes, and these features are discussed here along with the $\mathrm{Ir}^{\mathrm{IV}} / \mathrm{Ir}^{\mathrm{III}}$ oxidation waves.

Table 3. Summary of electrochemical data for complexes 1-4.

\begin{tabular}{lll}
\hline & $\operatorname{Ir}^{\mathrm{IV}} / \mathrm{Ir}^{\mathrm{III}} E^{\mathrm{ox}}(\mathrm{V})$ & Fz-centered $E^{\mathrm{ed}}(\mathrm{V})$ \\
\hline $1 \mathrm{a} / 1 \mathrm{a}^{\prime}$ & -0.02 & $-1.96^{\mathrm{a}}$ \\
$1 \mathrm{~b}^{\prime}$ & -0.10 & $-1.97^{\mathrm{a}}$ \\
$1 \mathrm{c}^{\prime}$ & 0.23 & -1.95 \\
1d & 0.37 & -1.41 \\
1e & 0.55 & $-1.61,-2.10^{\mathrm{a}}$ \\
1f & 0.86 & $-1.26,-1.70$ \\
2a & 0.08 & $-1.83^{\mathrm{a}}$ \\
2b & -0.02 & $-1.89^{\mathrm{a}}$ \\
2c & 0.23 & $-1.79^{\mathrm{a}}$ \\
2d & 0.51 & $-1.31,-1.78$ \\
2e & 0.70 & $-1.50,-1.94^{\mathrm{a}}$ \\
2f & 1.15 & $-1.22,-1.71$ \\
3a & 0.01 & $-1.98^{\mathrm{a}}$ \\
3b & -0.06 & $-1.95^{\mathrm{a}}$ \\
3e & $0.68^{\mathrm{a}}$ & -1.72 \\
3f & 0.97 & $-1.29,-1.74$ \\
4a & 0.01 & $-1.96^{\mathrm{a}}$ \\
4f & $0.83^{\mathrm{a}}$ & $-1.27,-1.68$ \\
\hline
\end{tabular}

${ }^{\mathrm{a}}$ Irreversible wave. $E_{\mathrm{p}, \mathrm{c}}$ or $E_{\mathrm{p}, \mathrm{a}}$ is reported.

Overlaid CVs of complexes $\mathbf{2 a - 2 f}$ with different formazanate substituents (top) and overlaid CVs of four diarylformazanate complexes 1f, 2 f, $3 \mathrm{f}$, and $4 \mathrm{f}$ (bottom) are shown in Figure 3 . The first reduction wave for all complexes is assigned as a formazanate-centered one electron reduction which occurs in the range of -1.22 to $-1.98 \mathrm{~V}$ (all potentials referenced to the ferrocenium/ferrocene couple). The $\mathrm{F}_{2}$ ppy series $(\mathbf{2} \mathbf{a}-\mathbf{f})$ provides the best insight into the effect of the formazanate structure on the redox properties, since this series includes all six formazanate ligands studied here and all of them bind exclusively in the five-member chelate "open" form in these analogues. As the data in Figure 3 and Table 1 shows, the redox potentials in $2 \mathrm{a}-\mathrm{c}$ follow the trend expected from the electron donating/withdrawing attributes of the substituents, although the effects are modest. Moving from $\mathbf{2 a}$ to $\mathbf{2 b}$, where the $\mathrm{R}^{1}$ substituent is changed from $\mathrm{CH}_{3}$ to a more electron-donating $\mathrm{OCH}_{3}$, results in a cathodic (negative) shift of the reduction potential by $60 \mathrm{mV}$. Similarly, comparing $2 \mathrm{a}$ to $2 \mathrm{c}$, where the $p-\mathrm{C}_{6} \mathrm{H}_{4}-\mathrm{OCH}_{3} \mathrm{R}^{2}$ substituent is replaced with the more electron-withdrawing $p$-cyanophenyl, we note a $40 \mathrm{mV}$ anodic (positive) shift in the reduction potential. A much more dramatic change in potential occurs when electron-withdrawing cyano substituents are added to the $\mathrm{R}^{1}$ position, with the potential in $2 \mathrm{~d}$ more positive than that of $2 \mathrm{a}$ by over $500 \mathrm{mV}$. Similarly large effects are observed in $2 \mathrm{e}$ and $2 \mathrm{f}$, where the $\mathrm{R}^{2}$ aryl substituent 

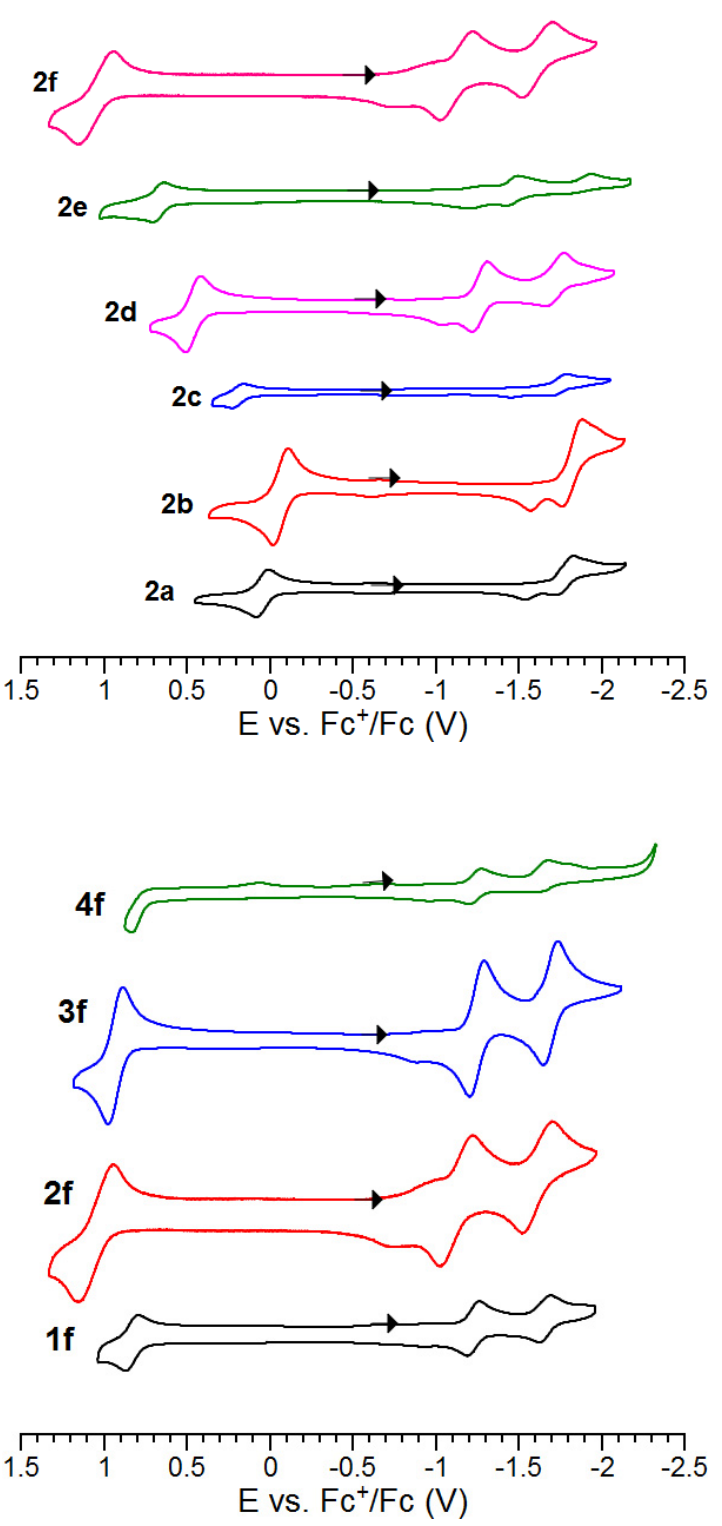

Figure 3. Overlaid cyclic voltammograms of complexes $2 \mathrm{a}-2 \mathrm{f}$ (top), and $\mathbf{1 f}, \mathbf{2 f}$, $3 \mathrm{f}$, and $\mathbf{4 f}$ (bottom). $\mathrm{CVs}$ were recorded in $\mathrm{CH}_{2} \mathrm{Cl}_{2}$ with 0.1 $\mathrm{M} \mathrm{NBu}_{4} \mathrm{PF}_{6}$ supporting electrolyte, using a glassy carbon working electrode and a scan rate of $0.1 \mathrm{~V} / \mathrm{s}$. The arrows indicate the scan direction. Concentrations were not carefully controlled, and currents are low in some of the plots because of limited solubility in $\mathrm{CH}_{2} \mathrm{Cl}_{2}$.

is replaced with a cyano group, resulting in comparatively mild formazanate-based reduction potentials, in particular in $2 \mathrm{f}\left(\mathrm{R}^{1}=\mathrm{R}^{2}=\mathrm{CN}\right.$, $\left.E_{\text {red }}=-1.22 \mathrm{~V}\right)$. Similar substituent effects are observed in the other members of the series with different cyclometalating ligands.

The effects of the cyclometalating ligand on the reduction potentials are modest, and in general the observed reduction potential is mainly determined by the substituent pattern on the formazanate. Fluorination of the phenylpyridine ligand causes an overall anodic shift ( $100 \mathrm{mV}$ on average) for complexes $2 \mathrm{a}-2 \mathrm{f}$ (Figure 3 ) if we compare them with the set $1 \mathrm{a}-1 \mathbf{f}$, but complexes with $\mathrm{C}^{\wedge} \mathrm{N}=$ bt or piq have very similar potentials to their ppy analogues, at parity of formazanate structure. In addition, the potentials for the complexes that were isolated as the "closed" isomer $\left(\mathbf{1} \mathbf{b}^{\prime}\right.$ and $\left.\mathbf{1} \mathbf{c}^{\prime}\right)$ or as a mixture of isomers (1a) are all very similar to the other members of the series with the same formazanate ligand, suggesting that the formazanate-centered LUMO energy and corresponding redox potential depend little on the binding mode of the formazanate.

All of the complexes here (except $3 e$ and $4 f$ ) also display a formal $\mathrm{Ir}^{\mathrm{IV}} / \mathrm{Ir}^{\mathrm{III}}$ redox couple which has slight dependence on the identity of the $\mathrm{C}^{\wedge} \mathrm{N}$ ligand but is highly sensitive to the identity of the formazanate ligands. Electron-rich complexes $1 \mathrm{a} / \mathbf{1 b}, \mathbf{2 a} / \mathbf{2 b}, \mathbf{3 a} / \mathbf{3 b}$ and 4a oxidize at similar potentials across the series, and again the isomeric form of the complex does not appear to have a large effect on the observed potential (Table 3 ). The oxidation potential of these seven complexes are very near the $\mathrm{Fc}^{+} / \mathrm{Fc}$ potential and again have a slight dependence on the formazanate substituents, with the most electron-rich Fzb complexes being easiest to oxidize. The addition of cyano substituents in the remaining complexes renders the complexes more difficult to oxidize, with shifts in potential that are qualitatively similar to those discussed above for the reduction potentials. The four Fzf complexes, where $\mathrm{R}^{1}=\mathrm{R}^{2}=\mathrm{CN}$, have the most positive oxidation potentials $(\geq 0.83 \mathrm{~V})$, and the complexes where only one of the $\mathrm{R}^{1}$ and $\mathrm{R}^{2}$ positions includes a cyano group (Fzc-e) have $\mathrm{Ir}^{\mathrm{IV}} / \mathrm{Ir}^{\mathrm{III}}$ potentials intermediate between the most electron-rich and electron-poor members of the series. As with the reduction potentials, the $\mathrm{C}^{\wedge} \mathrm{N}$ ligands exert a modest effect on the formally $\mathrm{Ir}^{\mathrm{IV}} / \mathrm{Ir}^{\mathrm{III}}$ couple, with $\mathrm{F}_{2}$ ppy complexes being the most difficult to oxidize for a given formazanate ligand. We note that although this oxidation potential can be formally classified as $\mathrm{Ir}^{\mathrm{IV}} / \mathrm{Ir}^{\mathrm{III}}$, and in typical cyclometalated iridium complexes the HOMO does include significant $\mathrm{Ir} d \pi$ character, ${ }^{63}$ the strong dependence of this potential on the formazanate structure implies that the HOMO in the complexes described here is also primarily formazanate ligand-centered, like the LUMO. Consistent with this supposition, previously reported platinum formazanate complexes from our group, ${ }^{49}$ as well as cyclometalated iridium complexes with structurally analogous $\beta$-diketiminate ancillary ligands, ${ }^{61}$ both have HOMOs that are almost exclusively formazanate or $\beta$-diketiminate-centered, with minor contribution from the metal.

One other noteworthy insight to come out of this work is the effect of the metal center and coordination geometry on the formazanate-centered optical transitions and redox properties. Our group has also prepared an extensive series of cyclometalated platinum formazanate complexes, ${ }^{50}$ using many of the same cyclometalating ligands and formazanates used in this work (except for Fzd, and piq, which we did not use to prepare any platinum complexes). In the UV-vis absorption spectra, in every case the low-energy formazanate $\pi \rightarrow \pi^{*}$ transition is significantly blue-shifted in the iridium complexes, by at least $23 \mathrm{~nm}\left(767 \mathrm{~cm}^{-1}\right)$ and as much as $122 \mathrm{~nm}\left(3650 \mathrm{~cm}^{-1}\right)$ when comparing $1 \mathrm{f}$ to its platinum congener. In the cyclic voltammograms, the formazanate-centered reduction potentials are substantially different as well, cathodically (negatively) shifted by at least $290 \mathrm{mV}$ and as much as $500 \mathrm{mV}$ in the iridium complexes. We do note that some of the reduction waves in the iridium complexes are irreversible, which makes these comparisons less quantitatively meaningful, but even in cases where both the platinum and iridium analogues have well-behaved, reversible reduction waves the iridium complex is more difficult to reduce by a substantial margin. Although electrochemical oxidation of the platinum complexes tends not to be as well-behaved and we have not investigated it as thoroughly, we 
can compare some complexes and we find that the iridium complexes are in general easier to oxidize, although the oxidation potentials are not as sensitive to the identity of the metal as the reduction potentials, in all cases differing by $<200 \mathrm{mV}$. Taken together, these observations indicate that, compared to cyclometalated platinum formazanate complexes, the iridium analogues have destabilized HOMO and LUMO energies and larger HOMO-LUMO gaps. The significant differences between the formazanate-centered properties in platinum and iridium complexes underscores the importance of d-orbital overlap with the formazanate in determining frontier orbital energies, an emerging theme in our work on formazanate $5 \mathrm{~d}$ metal complexes.

\section{Conclusion}

In this work, we disclose the first examples of cyclometalated iridium formazanate complexes prepared by a general synthetic strategy and a thorough study of the electronic modification of the formazanate ligand on the electrochemical and photophysical properties is also presented. Structural elucidation of the complexes reveals two distinct binding modes for the formazanate, with the typical six-membered chelate form and an unusual five-membered "open" structure both observed. A systematic comparison of different cyclometalated and formazanate ligands reveals that the redox potentials are much more sensitive to the identity of the substituents on the formazanate backbone. The UV-vis absorption features prove some predictable control of photophysical properties by tuning the formazanate and cyclometalated ligands independently. In future works, we plan to continue our exploration of $5 \mathrm{~d}$ metal formazanate complexes, further underscoring the effects of the metal identity, oxidation state, and coordination geometry on the formazanate-derived redox and optical properties.

\section{EXPERIMENTAL SECTION}

Materials. Reactions were carried out in a nitrogen atmosphere using standard Schlenk techniques. Solvents, starting materials, and reagents were of commercial origin and used without further purification unless stated otherwise below. Tetrahydrofuran (THF) and toluene for UV-vis spectroscopy, and acetonitrile and dichloromethane (DCM) for electrochemical measurements were dried by the method of Grubbs ${ }^{64}$, passing through dual alumina columns on a commercial solvent purification system (SPS). The acetonitrile was further dried by storage over 3A molecular sieves. Tetrabutylammonium hexafluorophosphate $\left(\mathrm{TBAPF}_{6}\right)$ was recrystallized from hot ethanol and ferrocene was sublimed at ambient pressure before use in electrochemical experiments. $\mathrm{CDCl}_{3}$ and $\mathrm{CD}_{3} \mathrm{CN}$ for NMR spectroscopy were stored over potassium carbonate and molecular sieves to remove acidic impurities and moisture. The ligands 3-p-methoxyphenyl-1,5-di-p-tolylformazan (Fza), 1,3,5-tri-p-methoxyphenylformazan (Fzb) and 3-p-cyanophenyl-1,5-di-p-tolylformazan (Fzc), and 3-p-tolyl-1,5-di-p-cyanophenylformazan (Fzd) were prepared by the method of Hicks et al. ${ }^{65}$ The ligands 3-cyano-1,5-di-ptolylformazan (Fze) and 3-cyano-1,5-di-p-cyanophenylformazan (Fzf) were prepared by following the literature procedures. ${ }^{31}$ The iridium precursors $\left[\operatorname{Ir}(\text { ppy })_{2}(\mu-\mathrm{Cl})\right]_{2}$ (ppy $=2$-phenylpyridine), $\left[\operatorname{Ir}\left(\mathrm{F}_{2} \text { ppy }\right)_{2}(\mu-\mathrm{Cl})\right]_{2} \quad\left(\mathrm{~F}_{2}\right.$ ppy $=2$-(2,4-difluorophenyl)pyridine $)$, $\left[\operatorname{Ir}(\mathrm{bt})_{2}(\mu-\mathrm{Cl})\right]_{2}(\mathrm{bt}=2$-phenylbenzothiazole $)$, and $\left[\operatorname{Ir}(\mathrm{piq})_{2}(\mu-\right.$ $\mathrm{Cl})]_{2}$ (piq = 1-phenylisoquinoline) were prepared by a modified version of the well-known Nonoyama procedure. ${ }^{66,67}$
Physical Methods. NMR spectra were recorded at room temperature using a JEOL ECA-600, ECA-500, or ECA-400 NMR spectrometer. UV-vis absorption spectra were recorded in THF, toluene, and $\mathrm{MeOH}$ solutions in screw-capped $1 \mathrm{~cm}$ quartz cuvettes using an Agilent Cary 8454 UV-vis spectrophotometer. Cyclic voltammetry (CV) measurements were performed with a $\mathrm{CH}$ Instruments $602 \mathrm{E}$ potentiostat interfaced with a nitrogen glovebox via wire feedthroughs. Samples were dissolved in dichloromethane $\left(\mathrm{CH}_{2} \mathrm{Cl}_{2}\right)$ with $0.1 \mathrm{M} \mathrm{TBAPF}_{6}$ as a supporting electrolyte. A $3 \mathrm{~mm}$ diameter glassy carbon working electrode, a platinum wire counter electrode, and a silver wire pseudo-reference electrode were used. Potentials were referenced to an internal standard of ferrocene. The bulk purity for all complexes is established by elemental analysis, performed by Atlantic Microlab, Inc.

$\operatorname{Ir}(\text { ppy })_{2}(\mathrm{Fza}) \quad\left(1 \mathrm{a} / 1 \mathrm{a}^{\prime}\right) . \quad\left[\operatorname{Ir}(\mathrm{ppy})_{2}(\mu-\mathrm{Cl})\right]_{2} \quad(101 \mathrm{mg}, 0.0942$ $\mathrm{mmol})$ and Fza $(67 \mathrm{mg}, 0.19 \mathrm{mmol})$ were combined in ethanol (15 $\mathrm{mL}$ ) with excess triethylamine $(0.10 \mathrm{~mL})$, and the mixture was deoxygenated under the protection of $\mathrm{N}_{2}$. The mixture was refluxed for $24 \mathrm{~h}$ and the color changed from red to green. The reaction completion was confirmed by TLC, which showed two green products of almost identical polarity, likely the "open" and "closed" isomers. The solvent was removed using rotary evaporation, and the product was re-dissolved in ethyl acetate to filter through neutral alumina in order to remove insoluble impurities. After removing ethyl acetate, column chromatography (hexane / ethyl acetate gradient eluent, neutral alumina) was performed to purify the product but attempts to separate the isomers using chromatography was not successful. Both isomers were eluted together from the column, and the combined products were recrystallized ( $\mathrm{THF} /$ pentane) later to get dark green solid. NMR analysis suggests a ca. 2:1 ratio of the "open" (1a) and "closed" $\left(1 \mathbf{a}^{\prime}\right)$ isomers, which results in very similar integration values for the resonances associated with each isomer. As such, a clear assignment of the peaks was not possible, and integration values for the ${ }^{1} \mathrm{H}$ NMR peaks are not provided. The spectrum is shown in Figure $S 2$ with relative integration values shown. Yield: 83 $\operatorname{mg}(51 \%) .{ }^{1} \mathrm{H} \mathrm{NMR}\left(400 \mathrm{MHz}, \mathrm{CDCl}_{3}\right) \delta: 8.70(\mathrm{~d}, J=5.6 \mathrm{~Hz}, \mathrm{ArH})$, $8.63(\mathrm{~d}, J=5.6 \mathrm{~Hz}, \mathrm{ArH}) 8.43(\mathrm{~d}, J=6.0 \mathrm{~Hz}, \mathrm{ArH}), 7.93$ (d, $J=7.8$ $\mathrm{Hz}, \mathrm{ArH}$ ), 7.58-7.87 (m, ArH), 7.30 (d, J=7.8 Hz, ArH), 7.20 (dd, $J=5.9 \mathrm{~Hz}, \operatorname{ArH}), 6.94-7.11(\mathrm{~m}, \operatorname{ArH}), 6.86(\mathrm{~d}, J=7.8 \mathrm{~Hz}, \operatorname{ArH})$, $6.73(\mathrm{t}, J=7.3 \mathrm{~Hz}, \mathrm{ArH}), 6.47-6.69(\mathrm{~m}, \mathrm{ArH}), 6.12-6.38(\mathrm{~m}, \mathrm{ArH})$, 5.94 (d, $J=7.8 \mathrm{~Hz}, \operatorname{ArH}), 5.57$ (d, $J=7.8 \mathrm{~Hz}, \operatorname{ArH}), 3.80\left(\mathrm{~s}, \mathrm{OCH}_{3}\right.$, both isomers coincident), $2.12\left(\mathrm{~s}, \mathrm{CH}_{3}\right), 2.10\left(\mathrm{~s}, \mathrm{CH}_{3}\right), 2.04(\mathrm{~s}$, $\left.\mathrm{CH}_{3}\right) .{ }^{13} \mathrm{C}\left\{{ }^{1} \mathrm{H}\right\} \operatorname{NMR}\left(151 \mathrm{MHz}, \mathrm{CDCl}_{3}\right) \delta: 169.3,168.5,167.5$, $158.8,158.6,158.2,156.9,154.7,153.7,152.4,152.2,151.8,150.1$, 149.6, 149.0, 143.7, 143.5, 142.8, 136.8, 136.7, 136.5, 134.4, 134.3, 134.2, 133.8, 133.2, 131.1, 130.2, 129.6, 129.0, 128.8, 128.5, 128.3, $127.6,127.4,125.6,123.8,123.7,123.4,122.2,121.9,121.5,121.3$, 120.6, 120.1, 119.3, 119.0, 118.9, 118.7, 113.4, 55.47, 55.4, 20.94, 20.85. Anal. Calcd for $\mathrm{C}_{44} \mathrm{H}_{38} \mathrm{IrN}_{6} \mathrm{O}: \mathrm{C}, 61.52 ; \mathrm{H}, 4.46 ; \mathrm{N}, 9.78$. Found: C, 61.69; H, 4.47; N, 9.76.

$\operatorname{Ir}(\mathrm{ppy})_{2}(\mathrm{Fzb})\left(1 \mathrm{~b}^{\prime}\right)$. The title compound was prepared by the general method described above for complex $1 \mathrm{a} / 1 \mathrm{a}^{\prime}$, using $\left[\operatorname{Ir}(\text { ppy })_{2}(\mu\right.$ $\mathrm{Cl})]_{2}(50 \mathrm{mg}, 0.047 \mathrm{mmol})$ and $\mathrm{Fzb}(37 \mathrm{mg}, 0.094 \mathrm{mmol})$. The product was isolated as a mixture of isomers and recrystallized later $\left(\mathrm{CH}_{2} \mathrm{Cl}_{2} /\right.$ pentane $)$ to get a dark green solid. Yield: $36 \mathrm{mg}(43 \%)$. We were unable to obtain satisfactory elemental analysis for this compound, but the NMR spectrum in Figures S4 and S5 provide evidence for bulk purity. The minor impurity peaks in the ${ }^{1} \mathrm{H}$ NMR 
spectrum arise from a small amount of the "open" isomer $1 \mathrm{~b}$ present in the isolated product. ${ }^{1} \mathrm{H} \mathrm{NMR}\left(400 \mathrm{MHz}, \mathrm{CDCl}_{3}\right) \delta: 8.70(\mathrm{~d}, J=$ $5.5 \mathrm{~Hz}, 2 \mathrm{H}, \mathrm{ArH}), 7.82(\mathrm{~d}, J=8.7 \mathrm{~Hz}, 2 \mathrm{H}, \mathrm{ArH}), 7.60-7.71(\mathrm{~m}, 4 \mathrm{H}$, ArH), 7.21-7.28 (m, 2H, ArH), 6.95-7.03 (m, 2H, ArH), 6.86 (d, J $=8.7 \mathrm{~Hz}, 2 \mathrm{H}, \mathrm{ArH}), 6.65(\mathrm{t}, J=7.3 \mathrm{~Hz}, 2 \mathrm{H}, \mathrm{ArH}), 6.51-6.61(\mathrm{~m}, 6 \mathrm{H}$, ArH), 6.18-6.32 (m, 6H, ArH), $3.80\left(\mathrm{~s}, 3 \mathrm{H}, \mathrm{OCH}_{3}\right), 3.62(\mathrm{~s}, 6 \mathrm{H}$, $\left.\mathrm{OCH}_{3}\right) .{ }^{13} \mathrm{C}\left\{{ }^{1} \mathrm{H}\right\} \mathrm{NMR}\left(151 \mathrm{MHz}, \mathrm{CDCl}_{3}\right) \delta: 168.5,158.3,156.8$, 154.8, 150.0, 149.0, 148.9, 143.7, 136.9, 134.3, 133.8, 130.1, 128.9, 125.6, 124.6, 123.7, 121.5, 120.7, 118.8, 113.4, 113.1, 112.2, 55.47, 55.21 .

$\operatorname{Ir}(\text { ppy })_{2}($ Fzc $)\left(1 c^{\prime}\right) .\left[\operatorname{Ir}(\text { ppy })_{2}(\mu-\mathrm{Cl})\right]_{2}(54 \mathrm{mg}, 0.05 \mathrm{mmol})$ and Fzc $(34 \mathrm{mg}, 0.10 \mathrm{mmol})$ were combined in ethanol $(10 \mathrm{~mL})$ with excess triethylamine $(0.1 \mathrm{~mL})$, and the mixture was deoxygenated under the protection of $\mathrm{N}_{2}$. The mixture was refluxed for $36 \mathrm{~h}$, and the color changed from red to green. The reaction completion was confirmed by TLC. Solvent was removed using rotary evaporation, and the product was re-dissolved in a minimum amount of ethyl acetate. After that column chromatography (hexane / ethyl acetate gradient eluent, neutral alumina) was performed to purify the product, which was crystallized by vapor diffusion of pentane into a concentrated $\mathrm{CH}_{2} \mathrm{Cl}_{2}$ solution. Yield: $43 \mathrm{mg}$ (50\%). ${ }^{1} \mathrm{H}$ NMR (500 $\left.\mathrm{MHz}, \mathrm{CDCl}_{3}\right) \delta: 8.68(\mathrm{~d}, J=5.5 \mathrm{~Hz}, 2 \mathrm{H}, \mathrm{ArH}), 7.98(\mathrm{~d}, J=8.6 \mathrm{~Hz}$, 2H, ArH), 7.69-7.74 (m, 2H, ArH), 7.65 (d, $J=7.9 \mathrm{~Hz}, 2 \mathrm{H}, \mathrm{ArH})$, 7.52 (d, $J=8.6 \mathrm{~Hz}, 2 \mathrm{H}, \mathrm{ArH}), 7.18-7.20$ (m, 2H, ArH), 7.05 (ddd, $J$ $=7.2,5.8,1.2 \mathrm{~Hz}, 2 \mathrm{H}, \mathrm{ArH}), 6.61-6.65(\mathrm{~m}, 2 \mathrm{H}, \mathrm{ArH}), 6.57$ (dd, $J=$ 7.4, $1.1 \mathrm{~Hz}, 2 \mathrm{H}, \mathrm{ArH}), 6.53$ (d, J=8.1 Hz, 4H, ArH), 6.44 (d, J= 8.4 $\mathrm{Hz}, 4 \mathrm{H}, \mathrm{ArH}), 6.17$ (d, $J=7.0 \mathrm{~Hz}, 2 \mathrm{H}, \mathrm{ArH}), 2.11\left(\mathrm{~s}, 6 \mathrm{H}, \mathrm{CH}_{3}\right)$. ${ }^{13} \mathrm{C}\left\{{ }^{1} \mathrm{H}\right\}$ NMR $\left(151 \mathrm{MHz}, \mathrm{CDCl}_{3}\right) \delta: 168.5,153.8,153.7,149.7$, $146.8,146.0,143.5,137.2,134.9,133.7,131.7,129.0,127.6,124.1$, 123.7, 123.1, 121.8, 120.9, 120.4, 119.0, 107.6, 20.9. Anal. Calcd for $\mathrm{C}_{44} \mathrm{H}_{34} \mathrm{~N}_{7} \mathrm{Ir}$ : C, 61.95, H, 4.02, N, 11.49. Found: C, 62.04, H, 4.00, $\mathrm{N}, 11.36$.

$\operatorname{Ir}(\text { ppy })_{2}$ (Fzd) (1d). The title compound was prepared by the general method described above for complex $1 \mathbf{c}^{\prime}$, using $\left[\operatorname{Ir}(\text { ppy })_{2}(\mu-\right.$ $\mathrm{Cl})]_{2}$ (54 mg, $0.050 \mathrm{mmol}$ ) and Fzd (37 mg, $\left.0.10 \mathrm{mmol}\right)$. Yield: 62 $\operatorname{mg}(72 \%) .{ }^{1} \mathrm{H}$ NMR $\left(500 \mathrm{MHz}, \mathrm{CDCl}_{3}\right) \delta: 8.46(\mathrm{~d}, J=5.7 \mathrm{~Hz}, 1 \mathrm{H}$, $\operatorname{ArH}), 8.34$ (d, $J=5.6 \mathrm{~Hz}, 1 \mathrm{H}, \operatorname{ArH}), 7.83-7.88$ (m, 1H, ArH), 7.82 (d, $J=7.2 \mathrm{~Hz}, 1 \mathrm{H}, \operatorname{ArH}), 7.73(\mathrm{~d}, J=8.3 \mathrm{~Hz}, 2 \mathrm{H}, \operatorname{ArH}), 7.72$ (dd, $J$ $=7.1,1.3 \mathrm{~Hz}, 1 \mathrm{H}, \mathrm{ArH}), 7.68(\mathrm{~d}, J=7.2 \mathrm{~Hz}, 1 \mathrm{H}, \operatorname{ArH}), 7.33$ (dd, $J=$ 7.9, $1.0 \mathrm{~Hz}, 1 \mathrm{H}, \mathrm{ArH}), 7.25$ (d, $J=8.1 \mathrm{~Hz}, 1 \mathrm{H}, \operatorname{ArH}), 7.20(\mathrm{~s}, 2 \mathrm{H}$, $\mathrm{ArH}), 7.18$ (s, 2H, ArH), 7.10 (d, $J=8.9 \mathrm{~Hz}, 4 \mathrm{H}, \mathrm{ArH}), 6.87$ (d, $J=$ $8.6 \mathrm{~Hz}, 2 \mathrm{H}, \mathrm{ArH}), 6.79(\mathrm{td}, J=7.6,1.2 \mathrm{~Hz}, 1 \mathrm{H}, \mathrm{ArH}), 6.68-6.74(\mathrm{~m}$, $2 \mathrm{H}, \mathrm{ArH}), 6.40(\mathrm{td}, J=7.5,1.1 \mathrm{~Hz}, 1 \mathrm{H}, \mathrm{ArH}), 6.35(\mathrm{~d}, J=8.2 \mathrm{~Hz}$, $2 \mathrm{H}, \mathrm{ArH}), 5.91(\mathrm{dd}, J=7.8,0.9 \mathrm{~Hz}, 1 \mathrm{H}, \mathrm{ArH}), 5.63-5.67(\mathrm{~m}, 1 \mathrm{H}$, ArH), 2.37 (s, 3H, CH 3$).{ }^{13} \mathrm{C}\left\{{ }^{1} \mathrm{H}\right\} \operatorname{NMR}\left(151 \mathrm{MHz}, \mathrm{CDCl}_{3}\right) \delta$ : $168.9,167.4,161.3,160.4,157.0,155.9,155.3,151.6,149.1,148.3$, 147.2, 143.4, 142.6, 138.3, 137.6, 137.5, 132.1, 132.0, 130.7, 130.5, $130.2,129.7,129.1,128.9,124.3,124.2,122.6,122.5,122.3,122.2$, 121.1, 120.5, 119.8, 119.5, 119.4, 108.3, 105.7, 21.5. Anal. Calcd for $\mathrm{C}_{44} \mathrm{H}_{31} \mathrm{~N}_{8} \mathrm{Ir}$ : C, 61.17, H, 3.62, N, 12.97. Found: C, 61.03, H, 3.68, $\mathrm{N}, 12.72$.

$\operatorname{Ir}(\text { ppy })_{2}$ (Fze) (1e). The title compound was prepared by the general method described above for complex $1 \mathbf{c}^{\prime}$, using $\left[\operatorname{Ir}(\text { ppy })_{2}(\mu-\right.$ $\mathrm{Cl})]_{2}(54 \mathrm{mg}, 0.050 \mathrm{mmol})$ and Fze $(28 \mathrm{mg}, 0.10 \mathrm{mmol})$. Yield: 47 $\mathrm{mg}(60 \%) .{ }^{1} \mathrm{H} \mathrm{NMR}\left(500 \mathrm{MHz}, \mathrm{CDCl}_{3}\right) \delta: 8.37$ (d, $J=5.5 \mathrm{~Hz}, 1 \mathrm{H}$, $\mathrm{ArH}), 8.27$ (d, J=5.4 Hz, 1H, ArH), 7.78-7.83 (m, 1H, ArH), 7.76 (d, $J=7.7 \mathrm{~Hz}, 1 \mathrm{H}, \operatorname{ArH}), 7.68-7.72(\mathrm{~m}, 1 \mathrm{H}, \operatorname{ArH}), 7.65$ (d, $J=7.9$
$\mathrm{Hz}, 1 \mathrm{H}, \mathrm{ArH}$ ), 7.27 (s, 1H, ArH), 7.19 (d, $J=7.4 \mathrm{~Hz}, 1 \mathrm{H}, \mathrm{ArH}$ ), 7.12-7.16 (m, 1H, ArH), 7.05-7.09 (m, 1H, ArH), 6.82 (d, J= 8.5 $\mathrm{Hz}, 2 \mathrm{H}, \mathrm{ArH}), 6.74$ (td, $J=7.5,0.8 \mathrm{~Hz}, 1 \mathrm{H}, \mathrm{ArH}), 6.67$ (d, $J=7.8$ $\mathrm{Hz}, 3 \mathrm{H}, \mathrm{ArH}), 6.59$ (t, J=7.8 Hz, 1H, ArH), $6.38(\mathrm{~d}, J=8.0 \mathrm{~Hz}, 2 \mathrm{H}$, $\operatorname{ArH}), 6.30(\mathrm{t}, J=7.8 \mathrm{~Hz}, 1 \mathrm{H}, \mathrm{ArH}), 6.22(\mathrm{~d}, J=8.1 \mathrm{~Hz}, 2 \mathrm{H}, \mathrm{ArH})$, $5.89(\mathrm{~d}, J=7.5 \mathrm{~Hz}, 1 \mathrm{H}, \mathrm{ArH}), 5.55(\mathrm{~d}, J=7.5 \mathrm{~Hz}, 1 \mathrm{H}, \operatorname{ArH}), 2.13(\mathrm{~s}$, $\left.3 \mathrm{H}, \mathrm{CH}_{3}\right), 2.04\left(\mathrm{~s}, 3 \mathrm{H}, \mathrm{CH}_{3}\right) .{ }^{13} \mathrm{C}\left\{{ }^{1} \mathrm{H}\right\} \mathrm{NMR}\left(151 \mathrm{MHz}, \mathrm{CDCl}_{3}\right) \delta$ : $168.8,167.2$, 167.2, 153.7, 151.2, 150.6, 150.4, 149.7, 148.1, 143.4, $142.6,137.4,136.4,136.3,135.2,132.0,130.9,129.9,129.4,128.5$, $128.3,124.0,123.9,122.6,122.3,122.1,121.9,120.1,120.1,119.2$, 119.2, 116.2, 21.0, 21.0. Anal. Calcd for $\mathrm{C}_{38} \mathrm{H}_{30} \mathrm{~N}_{7} \mathrm{Ir}$ : C, 58.75, H, 3.89, N, 12.62. Found: C, 58.90, H, 3.89, N, 12.42 .

$\operatorname{Ir}(\mathrm{ppy})_{2}$ (Fzf) (1f). The title compound was prepared by the general method described above for complex $1 c^{\prime}$, using $\left[\operatorname{Ir}(\text { ppy })_{2}(\mu-\right.$ $\mathrm{Cl})]_{2}$ (54 mg, $\left.0.050 \mathrm{mmol}\right)$ and Fzf (30 mg, $\left.0.10 \mathrm{mmol}\right)$. Yield: 41 $\mathrm{mg}(52 \%) .{ }^{1} \mathrm{H} \mathrm{NMR}\left(500 \mathrm{MHz}, \mathrm{CD}_{3} \mathrm{CN}\right) \delta: 8.40(\mathrm{~d}, J=5.6 \mathrm{~Hz}, 1 \mathrm{H}$, $\operatorname{ArH}), 8.26$ (d, $J=5.5 \mathrm{~Hz}, 1 \mathrm{H}, \operatorname{ArH}), 7.97$ (t, $J=7.1 \mathrm{~Hz}, 1 \mathrm{H}, \mathrm{ArH}$ ), $7.91(\mathrm{~d}, J=8.0 \mathrm{~Hz}, 1 \mathrm{H}, \operatorname{ArH}), 7.85(\mathrm{t}, J=7.8 \mathrm{~Hz}, 1 \mathrm{H}, \operatorname{ArH}), 7.76(\mathrm{~d}$, $J=8.0 \mathrm{~Hz}, 1 \mathrm{H}, \mathrm{ArH}), 7.32$ (d, $J=7.7 \mathrm{~Hz}, 1 \mathrm{H}, \mathrm{ArH}), 7.28$ (dd, $J=$ 7.6, 4.3 Hz, 2H, ArH), 7.20-7.24 (m, 1H, ArH), 7.17 (d, J=8.7 Hz, $2 \mathrm{H}, \mathrm{ArH}), 7.00$ (d, $J=8.5 \mathrm{~Hz}, 2 \mathrm{H}, \operatorname{ArH}), 6.98(\mathrm{~d}, J=8.7 \mathrm{~Hz}, 2 \mathrm{H}$, $\operatorname{ArH}), 6.75(\mathrm{t}, J=7.0 \mathrm{~Hz}, 1 \mathrm{H}, \mathrm{ArH}), 6.69(\mathrm{dd}, J=10.7,4.2 \mathrm{~Hz}, 1 \mathrm{H}$, $\operatorname{ArH}), 6.66$ (dd, $J=11.5,4.2 \mathrm{~Hz}, 1 \mathrm{H}, \operatorname{ArH}), 6.49$ (d, $J=8.4 \mathrm{~Hz}, 2 \mathrm{H}$, $\operatorname{ArH}), 6.40(\mathrm{t}, J=6.9 \mathrm{~Hz}, 1 \mathrm{H}, \mathrm{ArH}), 5.83(\mathrm{~d}, J=7.6 \mathrm{~Hz}, 1 \mathrm{H}, \mathrm{ArH})$, $5.60(\mathrm{~d}, J=7.5 \mathrm{~Hz}, 1 \mathrm{H}, \mathrm{ArH}) .{ }^{13} \mathrm{C}\left\{{ }^{1} \mathrm{H}\right\} \mathrm{NMR}\left(151 \mathrm{MHz}, \mathrm{CD}_{3} \mathrm{CN}\right) \delta$ : $167.7,166.1,155.3,154.2$, 152.5, 151.5, 150.5, 146.8, 144.0, 143.2, $138.8,138.8,137.9,137.2,132.2,132.0,130.6,129.9,129.4,124.4$, 124.1, 123.9, 123.5, 123.0, 122.6, 121.1, 120.6, 120.1, 119.7, 118.7, 118.64, 114.6, 110.1, 108.1. Anal. Calcd for $\mathrm{C}_{38} \mathrm{H}_{24} \mathrm{~N}_{9} \mathrm{Ir}$ : C, 57.13, H, 3.03, N, 15.78. Found: C, 57.30, H, 3.18, N, 15.56.

$\operatorname{Ir}\left(\mathrm{F}_{2} \mathrm{ppy}\right)_{2}(\mathrm{Fza})(2 \mathrm{a})$. The title compound was prepared by the general method described above for complex $1 c^{\prime}$, using $\left[\operatorname{Ir}\left(\mathrm{F}_{2} \text { ppy }\right)_{2}(\mu-\mathrm{Cl})\right]_{2}(61 \mathrm{mg}, 0.050 \mathrm{mmol})$ and Fza $(36 \mathrm{mg}, 0.10$ mmol). Yield: $76 \mathrm{mg}(82 \%) .{ }^{1} \mathrm{H} \mathrm{NMR}\left(500 \mathrm{MHz}, \mathrm{CD}_{3} \mathrm{CN}\right) \delta: 8.57$ $(\mathrm{d}, J=4.3 \mathrm{~Hz}, 1 \mathrm{H}, \mathrm{ArH}), 8.44$ (d, $J=4.5 \mathrm{~Hz}, 1 \mathrm{H}, \mathrm{ArH}), 8.17$ (d, $J=$ $6.9 \mathrm{~Hz}, 1 \mathrm{H}, \mathrm{ArH}), 8.03(\mathrm{~d}, J=6.9 \mathrm{~Hz}, 1 \mathrm{H}, \mathrm{ArH}), 7.92(\mathrm{~d}, J=8.1 \mathrm{~Hz}$, $2 \mathrm{H}, \mathrm{ArH}), 7.78-7.85(\mathrm{~m}, 1 \mathrm{H}, \mathrm{ArH}), 7.71(\mathrm{td}, J=8.0,1.2 \mathrm{~Hz}, 1 \mathrm{H}$, ArH), 7.11 (ddd, $J=7.3,5.9,1.4 \mathrm{~Hz}, 1 \mathrm{H}, \mathrm{ArH}$ ), 7.08 (ddd, $J=7.3$, 5.9, $1.4 \mathrm{~Hz}, 1 \mathrm{H}, \mathrm{ArH}), 6.88$ (dd, $J=7.0,3.0 \mathrm{~Hz}, 4 \mathrm{H}, \mathrm{ArH}), 6.71(\mathrm{~d}, J$ $=6.7 \mathrm{~Hz}, 2 \mathrm{H}, \mathrm{ArH}), 6.51(\mathrm{~d}, J=6.5 \mathrm{~Hz}, 2 \mathrm{H}, \operatorname{ArH}), 6.27$ (ddd, $J=$ $12.3,9.1,2.3 \mathrm{~Hz}, 1 \mathrm{H}, \mathrm{ArH}), 6.15$ (d, J=5.9 Hz, 2H, ArH), 6.06 (ddd, $J=12.5,9.3,2.3 \mathrm{~Hz}, 1 \mathrm{H}, \mathrm{ArH}), 5.41$ (dd, $J=7.0,1.8 \mathrm{~Hz}, 1 \mathrm{H}, \mathrm{ArH}$ ), $5.11(\mathrm{dd}, J=7.0,1.8 \mathrm{~Hz}, 1 \mathrm{H}, \mathrm{ArH}), 3.81\left(\mathrm{~s}, 3 \mathrm{H}, \mathrm{OCH}_{3}\right), 2.15(\mathrm{~s}, 3 \mathrm{H}$, $\mathrm{CH}_{3}$ ), 2.13 (s, 3H, $\left.\mathrm{CH}_{3}\right) .{ }^{13} \mathrm{C}\left\{{ }^{1} \mathrm{H}\right\} \mathrm{NMR}\left(126 \mathrm{MHz}, \mathrm{CD}_{3} \mathrm{CN}\right) \delta$ : $165.8\left(\mathrm{~d}, J_{C F}=5.3 \mathrm{~Hz}\right), 164.2\left(\mathrm{~d}, J_{C F}=5.5 \mathrm{~Hz}\right), 163.5\left(\mathrm{~d}, J_{C F}=10.2\right.$ $\mathrm{Hz}), 163.3,161.7\left(\mathrm{~d}, J_{C F}=9.8 \mathrm{~Hz}\right), 161.0\left(\mathrm{~d}, J_{C F}=7.7 \mathrm{~Hz}\right), 159.8(\mathrm{~d}$, $\left.J_{C F}=5.2 \mathrm{~Hz}\right), 158.8,158.4,154.2,152.2,151.8,151.6,149.8,137.9$, 137.7, 135.1, 133.9, 130.2, 128.6, 128.2, 127.5, 127.2, 126.9, 123.2 $\left(\mathrm{d}, J_{C F}=15.9 \mathrm{~Hz}\right), 122.9\left(\mathrm{~d}, J_{C F}=16.4 \mathrm{~Hz}\right), 122.5,122.2,121.7$, $120.4,113.9\left(\mathrm{~d}, J_{C F}=12.5 \mathrm{~Hz}\right), 113.5,113.0\left(\mathrm{~d}, J_{C F}=13.8 \mathrm{~Hz}\right), 97.7$ $\left(\mathrm{t}, J_{C F}=26.8 \mathrm{~Hz}\right), 95.9\left(\mathrm{t}, J_{C F}=27.1 \mathrm{~Hz}\right), 55.4,20.9,20.6 .{ }^{19} \mathrm{~F} \mathrm{NMR}$ $\left(470 \mathrm{MHz}, \mathrm{CDCl}_{3}\right) \delta:-107.6(\mathrm{dd}, J=19.0,9.2 \mathrm{~Hz}, 1 \mathrm{~F}),-109.4$ (dd, $J=18.9,9.4 \mathrm{~Hz}, 1 \mathrm{~F}),-110.2(\mathrm{t}, J=12.4 \mathrm{~Hz}, 1 \mathrm{~F}),-111.1(\mathrm{t}, J=11.4$ $\mathrm{Hz}, 1 \mathrm{~F})$. Anal. Calcd for $\mathrm{C}_{44} \mathrm{H}_{33} \mathrm{~N}_{6} \mathrm{~F}_{4} \mathrm{OIr}$ : C, 56.83, H, 3.58, N, 9.04. Found: C, 56.76, H, 3.67, N, 8.90.

$\operatorname{Ir}\left(\mathrm{F}_{2} \mathrm{ppy}\right)_{2}(\mathrm{Fzb})(2 \mathrm{~b})$. The title compound was prepared by the general method described above for complex $1 \mathbf{c}^{\prime}$, using 
$\left[\operatorname{Ir}\left(\mathrm{F}_{2} \mathrm{ppy}\right)_{2}(\mu-\mathrm{Cl})\right]_{2}(61 \mathrm{mg}, 0.050 \mathrm{mmol})$ and $\mathrm{Fzb}(39 \mathrm{mg}, 0.10$ mmol). Yield: $53 \mathrm{mg}(55 \%) .{ }^{1} \mathrm{H} \mathrm{NMR}\left(500 \mathrm{MHz}, \mathrm{CD}_{3} \mathrm{CN}\right) \delta: 8.58-$ $8.62(\mathrm{~m}, 1 \mathrm{H}, \mathrm{ArH}), 8.46(\mathrm{~d}, J=5.5 \mathrm{~Hz}, 1 \mathrm{H}, \mathrm{ArH}), 8.13(\mathrm{~d}, J=8.6$ $\mathrm{Hz}, 1 \mathrm{H}, \mathrm{ArH}), 7.99(\mathrm{~d}, J=8.4 \mathrm{~Hz}, 1 \mathrm{H}, \mathrm{ArH}), 7.93-7.97(\mathrm{~m}, 1 \mathrm{H}$, $\mathrm{ArH}), 7.83(\mathrm{dd}, J=11.7,5.1 \mathrm{~Hz}, 1 \mathrm{H}, \mathrm{ArH}), 7.68(\mathrm{~d}, J=9.0 \mathrm{~Hz}, 2 \mathrm{H}$, $\operatorname{ArH}), 7.29(\mathrm{t}, J=7.3 \mathrm{~Hz}, 1 \mathrm{H}, \mathrm{ArH}), 7.24(\mathrm{t}, J=6.6 \mathrm{~Hz}, 1 \mathrm{H}, \mathrm{ArH})$, $6.88(\mathrm{~d}, J=9.0 \mathrm{~Hz}, 2 \mathrm{H}, \mathrm{ArH}), 6.72(\mathrm{~d}, J=9.0 \mathrm{~Hz}, 2 \mathrm{H}, \mathrm{ArH}), 6.41(\mathrm{~d}$, $J=6.9 \mathrm{~Hz}, 2 \mathrm{H}, \mathrm{ArH}), 6.38-6.42(\mathrm{~m}, 1 \mathrm{H}, \mathrm{ArH}), 6.30(\mathrm{~d}, J=9.1 \mathrm{~Hz}$, $2 \mathrm{H}, \mathrm{ArH}), 6.21(\mathrm{~d}, J=8.1 \mathrm{~Hz}, 2 \mathrm{H}, \mathrm{ArH}), 6.06-6.12(\mathrm{~m}, 1 \mathrm{H}, \mathrm{ArH})$, $5.43(\mathrm{dd}, J=7.6,3.5 \mathrm{~Hz}, 1 \mathrm{H}, \mathrm{ArH}), 5.21(\mathrm{dd}, J=8.9,2.4 \mathrm{~Hz}, 1 \mathrm{H}$, $\mathrm{ArH}), 3.77\left(\mathrm{~s}, 3 \mathrm{H}, \mathrm{OCH}_{3}\right), 3.62\left(\mathrm{~s}, 3 \mathrm{H}, \mathrm{OCH}_{3}\right), 3.60\left(\mathrm{~s}, 3 \mathrm{H}, \mathrm{OCH}_{3}\right)$. ${ }^{13} \mathrm{C}\left\{{ }^{1} \mathrm{H}\right\} \operatorname{NMR}\left(126 \mathrm{MHz}, \mathrm{CD}_{3} \mathrm{CN}\right) \delta: 164.9\left(\mathrm{~d}, J_{C F}=7.1 \mathrm{~Hz}\right), 163.2$ $\left(\mathrm{d}, J_{C F}=7.4 \mathrm{~Hz}\right), 162.4\left(\mathrm{~d}, J_{C F}=5.2 \mathrm{~Hz}\right), 161.7\left(\mathrm{~d}, J_{C F}=12.1 \mathrm{~Hz}\right)$, $161.6\left(\mathrm{~d}, J_{C F}=13.8 \mathrm{~Hz}\right), 161.5,159.7\left(\mathrm{~d}, J_{C F}=4.7 \mathrm{~Hz}\right), 159.6\left(\mathrm{~d}, J_{C F}\right.$ $=3.9 \mathrm{~Hz}), 158.8,158.4,157.5,156.5,154.7\left(\mathrm{~d}, J_{C F}=6.3 \mathrm{~Hz}\right), 151.8$, $150.8,148.1,147.6,138.7,138.6,130.5,127.7,127.4,123.5,123.3$ $\left(\mathrm{d}, J_{C F}=19.9 \mathrm{~Hz}\right), 123.1,123.0,122.7\left(\mathrm{~d}, J_{C F}=20.4 \mathrm{~Hz}\right), 121.8$, 114.1 (d, $\left.J_{C F}=16.5 \mathrm{~Hz}\right), 113.1,112.9,112.8,112.6,97.31,96.16$, 55.0, 54.9, 54.8. ${ }^{19} \mathrm{~F}$ NMR $\left(470 \mathrm{MHz}, \mathrm{CD}_{3} \mathrm{CN}\right) \delta:-109.5(\mathrm{dd}, J=$ $18.8,9.4 \mathrm{~Hz}, 1 \mathrm{~F}),-111.2(\mathrm{q}, J=9.5 \mathrm{~Hz}, 1 \mathrm{~F}),-111.7(\mathrm{t}, J=11.8 \mathrm{~Hz}$, $1 \mathrm{~F}),-111.8(\mathrm{t}, J=11.8 \mathrm{~Hz}, 1 \mathrm{~F})$. Anal. Calcd for $\mathrm{C}_{44} \mathrm{H}_{33} \mathrm{~N}_{6} \mathrm{~F}_{4} \mathrm{O}_{3} \mathrm{Ir}: \mathrm{C}$, 54.94, H, 3.46, N, 8.74. Found: C, 54.76, H, 3.51, N, 8.57.

$\operatorname{Ir}\left(\mathrm{F}_{2} \mathrm{ppy}\right)_{2}(\mathrm{Fzc})(2 \mathrm{c})$. The title compound was prepared by the general method described above for complex $1 \mathrm{c}^{\prime}$, using $\left[\operatorname{Ir}\left(\mathrm{F}_{2} \mathrm{ppy}\right)_{2}(\mu-\mathrm{Cl})\right]_{2}(61 \mathrm{mg}, 0.050 \mathrm{mmol})$ and Fzc $(34 \mathrm{mg}, 0.10$ mmol). Yield: $67 \mathrm{mg}(73 \%) .{ }^{1} \mathrm{H} \mathrm{NMR}\left(500 \mathrm{MHz}, \mathrm{CDCl}_{3}\right) \delta: 8.48$ $(\mathrm{d}, J=5.9 \mathrm{~Hz}, 1 \mathrm{H}, \mathrm{ArH}), 8.40(\mathrm{~d}, J=6.5 \mathrm{~Hz}, 1 \mathrm{H}, \operatorname{ArH}), 8.18(\mathrm{~d}, J=$ $8.4 \mathrm{~Hz}, 3 \mathrm{H}, \mathrm{ArH}), 8.03(\mathrm{~d}, J=9.2 \mathrm{~Hz}, 1 \mathrm{H}, \operatorname{ArH}), 7.85(\mathrm{t}, J=7.8 \mathrm{~Hz}$, $1 \mathrm{H}, \mathrm{ArH}), 7.74(\mathrm{t}, J=7.8 \mathrm{~Hz}, 1 \mathrm{H}, \mathrm{ArH}), 7.57(\mathrm{~d}, J=8.4 \mathrm{~Hz}, 2 \mathrm{H}$, $\operatorname{ArH}), 7.14(\mathrm{t}, J=6.6 \mathrm{~Hz}, 1 \mathrm{H}, \mathrm{ArH}), 7.11(\mathrm{t}, J=6.6 \mathrm{~Hz}, 1 \mathrm{H}, \mathrm{ArH})$, $6.80(\mathrm{~d}, J=8.4 \mathrm{~Hz}, 2 \mathrm{H}, \mathrm{ArH}), 6.73(\mathrm{~d}, J=8.4 \mathrm{~Hz}, 2 \mathrm{H}, \mathrm{ArH}), 6.56(\mathrm{~d}$, $J=8.2 \mathrm{~Hz}, 2 \mathrm{H}, \mathrm{ArH}), 6.23-6.31(\mathrm{~m}, 1 \mathrm{H}, \mathrm{ArH}), 6.18(\mathrm{~d}, J=7.8 \mathrm{~Hz}$, $2 \mathrm{H}, \mathrm{ArH}), 6.06-6.12(\mathrm{~m}, 1 \mathrm{H}, \mathrm{ArH}), 5.37(\mathrm{dd}, J=8.7,2.3 \mathrm{~Hz}, 1 \mathrm{H}$, $\mathrm{ArH}), 5.11(\mathrm{dd}, J=8.6,2.3 \mathrm{~Hz}, 1 \mathrm{H}, \mathrm{ArH}), 2.17\left(\mathrm{~s}, 3 \mathrm{H}, \mathrm{CH}_{3}\right), 2.15$ $\left(\mathrm{s}, 3 \mathrm{H}, \mathrm{CH}_{3}\right) .{ }^{13} \mathrm{C}\left\{{ }^{1} \mathrm{H}\right\} \mathrm{NMR}\left(151 \mathrm{MHz}, \mathrm{CDCl}_{3}\right) \delta: 165.7\left(\mathrm{~d}, J_{C F}=\right.$ $5.5 \mathrm{~Hz}), 164.1\left(\mathrm{~d}, J_{C F}=4.7 \mathrm{~Hz}\right), 163.6\left(\mathrm{~d}, J_{C F}=2.4 \mathrm{~Hz}\right), 160.6,160.0$ $\left(\mathrm{d}, J_{C F}=4.2 \mathrm{~Hz}\right), 155.8,153.0\left(\mathrm{~d}, J_{C F}=5.8 \mathrm{~Hz}\right), 151.5,151.3,151.1$, 149.6, 138.5, 138.1, 138.0, 136.0, 134.9, 131.9, 128.7, 128.3, 128.3, 127.3, 127.2, 123.4, 123.2, 123.1, 122.7, 122.5, 121.9, 120.3, 119.7, $113.9\left(\mathrm{~d}, J_{C F}=13.2 \mathrm{~Hz}\right), 113.4,112.9\left(\mathrm{~d}, J_{C F}=13.9 \mathrm{~Hz}\right), 109.3,97.99$ $\left(\mathrm{t}, J_{C F}=26 \mathrm{~Hz}\right), 96.41,96.24,21.0,20.7 .{ }^{19} \mathrm{~F}$ NMR $(470 \mathrm{MHz}$, $\left.\mathrm{CDCl}_{3}\right) \delta:-107.2(\mathrm{dd}, J=15.1,7.4 \mathrm{~Hz}, 1 \mathrm{~F}),-108.9(\mathrm{dd}, J=15.0$, $7.4 \mathrm{~Hz}, 1 \mathrm{~F}),-110.0(\mathrm{t}, J=9.2 \mathrm{~Hz}, 1 \mathrm{~F}),-110.6(\mathrm{t}, J=9.1 \mathrm{~Hz}, 1 \mathrm{~F})$. Anal. Calcd for $\mathrm{C}_{44} \mathrm{H}_{30} \mathrm{~N}_{7} \mathrm{~F}_{4} \mathrm{Ir}$ : C, 57.13, H, 3.27, N, 10.60. Found: C, 57.14, H, 3.42, N, 10.46 .

$\operatorname{Ir}\left(\mathrm{F}_{2} \mathrm{ppy}\right)_{2}(\mathrm{Fzd})(2 \mathrm{~d})$. The title compound was prepared by the general method described above for complex $1 \mathrm{c}^{\prime}$, using $\left[\operatorname{Ir}\left(\mathrm{F}_{2} \mathrm{ppy}\right)_{2}(\mu-\mathrm{Cl})\right]_{2}(61 \mathrm{mg}, 0.050 \mathrm{mmol})$ and $\mathrm{Fzd}(37 \mathrm{mg}, 0.10$ mmol). Yield: $75 \mathrm{mg}(80 \%) .{ }^{1} \mathrm{H} \mathrm{NMR}\left(500 \mathrm{MHz}, \mathrm{CDCl}_{3}\right) \delta: 8.41$ $(\mathrm{d}, J=5.8 \mathrm{~Hz}, 1 \mathrm{H}, \operatorname{ArH}), 8.37(\mathrm{~d}, J=5.7 \mathrm{~Hz}, 1 \mathrm{H}, \operatorname{ArH}), 8.21(\mathrm{~d}, J=$ $8.4 \mathrm{~Hz}, 1 \mathrm{H}, \mathrm{ArH}), 8.08(\mathrm{~d}, J=8.3 \mathrm{~Hz}, 1 \mathrm{H}, \mathrm{ArH}), 7.93(\mathrm{t}, J=7.9 \mathrm{~Hz}$, $1 \mathrm{H}, \mathrm{ArH}), 7.79(\mathrm{t}, J=7.9 \mathrm{~Hz}, 1 \mathrm{H}, \mathrm{ArH}), 7.72(\mathrm{dd}, J=8.1,1.6 \mathrm{~Hz}$, $2 \mathrm{H}, \mathrm{ArH}), 7.14-7.22(\mathrm{~m}, 6 \mathrm{H}, \mathrm{ArH}), 7.12(\mathrm{dd}, J=8.8,1.9 \mathrm{~Hz}, 2 \mathrm{H}$, ArH), 7.03-7.06 (m, 2H, ArH), $6.35(\mathrm{~d}, J=8.8 \mathrm{~Hz}, 3 \mathrm{H}, \mathrm{ArH}), 6.23$ (dd, $J=12.1,9.4 \mathrm{~Hz}, 1 \mathrm{H}, \mathrm{ArH}), 5.35-5.40(\mathrm{~m}, 1 \mathrm{H}, \mathrm{ArH}), 5.15-5.19$ (m, $1 \mathrm{H}, \mathrm{ArH}), 2.37\left(\mathrm{~s}, 3 \mathrm{H}, \mathrm{CH}_{3}\right) .{ }^{13} \mathrm{C}\left\{{ }^{1} \mathrm{H}\right\} \mathrm{NMR}\left(151 \mathrm{MHz}, \mathrm{CDCl}_{3}\right)$ $\delta: 165.5\left(\mathrm{~d}, J_{C F}=7.0 \mathrm{~Hz}\right), 164.0,163.8\left(\mathrm{~d}, J_{C F}=7.5 \mathrm{~Hz}\right), 162.0(\mathrm{dd}$, $\left.J_{C F}=17.4,11.9 \mathrm{~Hz}\right), 161.7\left(\mathrm{~d}, J_{C F}=7.7 \mathrm{~Hz}\right), 161.0,160.1,160.0$, $159.0\left(\mathrm{~d}, J_{C F}=6.0 \mathrm{~Hz}\right), 156.5,155.6,152.0\left(\mathrm{~d}, J_{C F}=6.8 \mathrm{~Hz}\right), 151.6$, 149.2, 138.7, 138.7, 132.3, 131.5, 129.8, 129.1, 129.0, 127.4, 127.1, $123.7\left(\mathrm{~d}, J_{C F}=19.8 \mathrm{~Hz}\right), 123.4\left(\mathrm{~d}, J_{C F}=19.8 \mathrm{~Hz}\right), 123.0,122.9$, $122.0,120.7,119.5,118.6,114.2\left(\mathrm{~d}, J_{C F}=17.8 \mathrm{~Hz}\right), 112.9\left(\mathrm{~d}, J_{C F}=\right.$ $18.0 \mathrm{~Hz}), 109.0,106.8,98.8\left(\mathrm{t}, J_{C F}=26.6 \mathrm{~Hz}\right), 97.6\left(\mathrm{t}, J_{C F}=26.6 \mathrm{~Hz}\right)$, 21.5. ${ }^{19} \mathrm{~F}$ NMR $\left(470 \mathrm{MHz}, \mathrm{CDCl}_{3}\right) \delta:-105.8(\mathrm{dd}, J=8.6,10 \mathrm{~Hz}$, $1 \mathrm{~F}),-107.0(\mathrm{dd}, J=8.6,10 \mathrm{~Hz}, 1 \mathrm{~F}),-108.7(\mathrm{t}, \mathrm{J}=11 \mathrm{~Hz}, 1 \mathrm{~F})$, $-109.2(\mathrm{t}, J=10 \mathrm{~Hz}, 1 \mathrm{~F})$. Anal. Calcd for $\mathrm{C}_{44} \mathrm{H}_{27} \mathrm{~N}_{8} \mathrm{~F}_{4} \mathrm{Ir}: \mathrm{C}, 56.46, \mathrm{H}$, 2.91, N, 11.97. Found: C, 56.22, H, 3.13, N, 11.70.

$\operatorname{Ir}\left(\mathrm{F}_{2} \text { ppy }\right)_{2}(\mathrm{Fze})(2 \mathrm{e})$. The title compound was prepared by the general method described above for complex $1 \mathbf{c}^{\prime}$, using $\left[\operatorname{Ir}\left(\mathrm{F}_{2} \mathrm{ppy}\right)_{2}(\mu-\mathrm{Cl})\right]_{2}(61 \mathrm{mg}, 0.050 \mathrm{mmol})$ and Fze $(28 \mathrm{mg}, 0.10$ mmol). Yield: $46 \mathrm{mg}(54 \%) .{ }^{1} \mathrm{H}$ NMR $\left(400 \mathrm{MHz}, \mathrm{CDCl}_{3}\right) \delta: 8.32$ $(\mathrm{d}, J=5.6 \mathrm{~Hz}, 1 \mathrm{H}), 8.27(\mathrm{~d}, J=5.7 \mathrm{~Hz}, 1 \mathrm{H}, \mathrm{ArH}), 8.16(\mathrm{~d}, J=8.7$ $\mathrm{Hz}, 1 \mathrm{H}, \mathrm{ArH}), 8.03(\mathrm{~d}, J=9.1 \mathrm{~Hz}, 1 \mathrm{H}, \mathrm{ArH}), 7.89(\mathrm{t}, J=7.9 \mathrm{~Hz}, 1 \mathrm{H}$, $\operatorname{ArH}), 7.79(\mathrm{t}, J=7.9 \mathrm{~Hz}, 1 \mathrm{H}, \operatorname{ArH}), 7.20-7.24(\mathrm{~m}, 1 \mathrm{H}, \operatorname{ArH})$, 7.13Ą7.19 (m, 1H, ArH), $6.72(\mathrm{~s}, 4 \mathrm{H}, \mathrm{ArH}), 6.56(\mathrm{~d}, J=8.0 \mathrm{~Hz}, 2 \mathrm{H}$, ArH), 6.24-6.33 (m, $1 \mathrm{H}, \mathrm{ArH}), 6.20(\mathrm{~d}, J=8.0 \mathrm{~Hz}, 2 \mathrm{H}, \mathrm{ArH}), 6.05-$ $6.15(\mathrm{~m}, 1 \mathrm{H}, \mathrm{ArH}), 5.34(\mathrm{~d}, J=6.7 \mathrm{~Hz}, 1 \mathrm{H}, \mathrm{ArH}), 5.06(\mathrm{~d}, J=8.6$ $\mathrm{Hz}, 1 \mathrm{H}, \mathrm{ArH}), 2.17\left(\mathrm{~s}, 3 \mathrm{H}, \mathrm{CH}_{3}\right), 2.13\left(\mathrm{~s}, 3 \mathrm{H}, \mathrm{CH}_{3}\right) .{ }^{13} \mathrm{C}\left\{{ }^{1} \mathrm{H}\right\} \mathrm{NMR}$ $\left(151 \mathrm{MHz}, \mathrm{CDCl}_{3}\right) \delta: 166.3,163.7\left(\mathrm{~d}, J_{C F}=6.7 \mathrm{~Hz}\right), 161.9\left(\mathrm{t}, J_{C F}=\right.$ $11.7 \mathrm{~Hz}), 161.6\left(\mathrm{~d}, J_{C F}=12.3 \mathrm{~Hz}\right), 159.9,157.7\left(\mathrm{~d}, J_{C F}=6.5 \mathrm{~Hz}\right)$, $151.8,151.7$ (d, $\left.J_{C F}=7.2 \mathrm{~Hz}\right), 151.2,150.3,149.9,149.8,138.6$, $137.0,136.1,128.7,128.3,127.8,127.3,127.0,123.4,123.3\left(\mathrm{~d}, J_{C F}=\right.$ $20.4 \mathrm{~Hz}), 123.1,122.8\left(\mathrm{~d}, J_{C F}=39.7 \mathrm{~Hz}\right), 122.3,121.9,120.1,115.5$, $114.2\left(\mathrm{~d}, J_{C F}=17.0 \mathrm{~Hz}\right), 113.0\left(\mathrm{~d}, J_{C F}=16.8 \mathrm{~Hz}\right), 98.4\left(\mathrm{t}, J_{C F}=27.0\right.$ $\mathrm{Hz}), 96.7\left(\mathrm{t}, J_{C F}=25.5 \mathrm{~Hz}\right), 21.0,20.8 .{ }^{19} \mathrm{~F} \mathrm{NMR}\left(470 \mathrm{MHz}, \mathrm{CDCl}_{3}\right)$ $\delta:-106.7(\mathrm{dd}, J=19.1,9.1 \mathrm{~Hz}, 1 \mathrm{~F}),-108.4(\mathrm{dd}, J=19.1,9.4 \mathrm{~Hz}$, $1 \mathrm{~F}),-109.7(\mathrm{t}, J=11.6 \mathrm{~Hz}, 1 \mathrm{~F}),-110.2(\mathrm{t}, J=11.6 \mathrm{~Hz}, 1 \mathrm{~F})$. Anal. Calcd for $\mathrm{C}_{38} \mathrm{H}_{26} \mathrm{~N}_{7} \mathrm{~F}_{4} \mathrm{Ir}$ : C, 53.77, H, 3.09, N, 11.55. Found: C, 53.75, H, 3.26, N, 11.62.

$\operatorname{Ir}\left(\mathrm{F}_{2} \mathrm{ppy}\right)_{2}(\mathrm{Fzf})(2 \mathrm{f})$. The title compound was prepared by the general method described above for complex $1 \mathrm{c}^{\prime}$, using $\left[\operatorname{Ir}\left(\mathrm{F}_{2} \text { ppy }\right)_{2}(\mu-\right.$ $\mathrm{Cl})]_{2}(61 \mathrm{mg}, 0.050 \mathrm{mmol})$ and Fzf $(30 \mathrm{mg}, 0.10 \mathrm{mmol})$. Yield: 51 $\mathrm{mg}(58 \%) .{ }^{1} \mathrm{H}$ NMR $\left(500 \mathrm{MHz}, \mathrm{CD}_{3} \mathrm{CN}\right) \delta: 8.44(\mathrm{~d}, J=5.1 \mathrm{~Hz}, 1 \mathrm{H}$, $\operatorname{ArH}), 8.31(\mathrm{~d}, J=6.5 \mathrm{~Hz}, 1 \mathrm{H}, \mathrm{ArH}), 8.14(\mathrm{~d}, J=8.4 \mathrm{~Hz}, 1 \mathrm{H}, \mathrm{ArH})$, $8.04(\mathrm{t}, J=8.1 \mathrm{~Hz}, 1 \mathrm{H}, \mathrm{ArH}), 8.00(\mathrm{~d}, J=8.4 \mathrm{~Hz}, 1 \mathrm{H}, \mathrm{ArH}), 7.92(\mathrm{t}$, $J=8.0 \mathrm{~Hz}, 1 \mathrm{H}, \mathrm{ArH}), 7.35$ (ddd, $J=7.4,5.8,1.4 \mathrm{~Hz}, 1 \mathrm{H}, \mathrm{ArH}), 7.29-$ $7.32(\mathrm{~m}, 1 \mathrm{H}, \mathrm{ArH}), 7.26-7.29(\mathrm{~m}, 2 \mathrm{H}, \mathrm{ArH}), 7.21(\mathrm{~d}, J=8.7 \mathrm{~Hz}, 2 \mathrm{H}$, $\operatorname{ArH}), 6.92(\mathrm{~d}, J=6.8 \mathrm{~Hz}, 2 \mathrm{H}, \operatorname{ArH}), 6.54(\mathrm{~d}, J=8.4 \mathrm{~Hz}, 2 \mathrm{H}, \operatorname{ArH})$, 6.42 (ddd, $J=12.6,9.3,2.3 \mathrm{~Hz}, 1 \mathrm{H}, \mathrm{ArH}$ ), 6.29 (ddd, $J=12.7,9.4$, $2.3 \mathrm{~Hz}, 1 \mathrm{H}, \mathrm{ArH}), 5.37$ (dd, $J=8.7,2.4 \mathrm{~Hz}, 1 \mathrm{H}, \operatorname{ArH}), 5.18$ (dd, $J=$ 8.7, $2.4 \mathrm{~Hz}, 1 \mathrm{H}, \mathrm{ArH}) .{ }^{13} \mathrm{C}\left\{{ }^{1} \mathrm{H}\right\} \mathrm{NMR}\left(151 \mathrm{MHz}, \mathrm{CD}_{3} \mathrm{CN}\right) \delta: 163.8$ $\left(\mathrm{d}, J_{C F}=7.2 \mathrm{~Hz}\right), 163.3,162.3\left(\mathrm{~d}, J_{C F}=6.6 \mathrm{~Hz}\right), 161.6\left(\mathrm{~d}, J_{C F}=12.5\right.$ $\mathrm{Hz}), 161.1,159.5\left(\mathrm{~d}, J_{C F}=3.8 \mathrm{~Hz}\right), 156.7\left(\mathrm{~d}, J_{C F}=6.9 \mathrm{~Hz}\right), 154.8$, $154.1,152.1,151.2,150.4,139.8\left(\mathrm{~d}, J_{C F}=15.9 \mathrm{~Hz}\right), 137.7,132.3$, 132.1, 131.7, 127.6, 124.5, 124.2, $123.8\left(\mathrm{~d}, J_{C F}=19.8 \mathrm{~Hz}\right), 123.6$, $123.5\left(\mathrm{~d}, J_{C F}=20.1 \mathrm{~Hz}\right), 123.0,121.0,118.5,118.2,114.4,114.1$, 112.9, 110.6, 108.8, $98.7\left(\mathrm{t}, J_{C F}=27.1 \mathrm{~Hz}\right), 97.4(\mathrm{t}, J=27.2 \mathrm{~Hz}) .{ }^{19} \mathrm{~F}$ NMR (470 MHz, $\left.\mathrm{CD}_{3} \mathrm{CN}\right) \delta:-107.8$ (dd, $\left.J=19.1,9.2 \mathrm{~Hz}, 1 \mathrm{~F}\right)$, $-109.4(\mathrm{dd}, J=19.0,9.4 \mathrm{~Hz}, 1 \mathrm{~F}),-110.6(\mathrm{t}, J=11.4 \mathrm{~Hz}, 1 \mathrm{~F}),-110.7$ $(\mathrm{t}, J=11.6 \mathrm{~Hz}, 1 \mathrm{~F})$. Anal. Calcd for $\mathrm{C}_{38} \mathrm{H}_{20} \mathrm{~N}_{9} \mathrm{~F}_{4} \mathrm{Ir}: \mathrm{C}, 52.41, \mathrm{H}, 2.31$, $\mathrm{N}, 14.48$. Found: C, 52.34, H, 2.59, N, 14.23.

$\operatorname{Ir}(\mathrm{bt})_{2}(\mathrm{Fza})(3 \mathrm{a})$. The title compound was prepared by the general method described above for complex $1 \mathrm{a} / 1 \mathrm{a}^{\prime}$, using $\left[\operatorname{Ir}(\mathrm{bt})_{2}(\mu-\mathrm{Cl})\right]_{2}$ $(51 \mathrm{mg}, 0.039 \mathrm{mmol})$ and Fza $(37 \mathrm{mg}, 0.10 \mathrm{mmol})$. The dark green solid product was isolated as a mixture of isomers where the major 
product was the five-member chelate with a trace amount of sixmember chelate evident from ${ }^{1} \mathrm{H}$ NMR data (Figure S32). Yield: 35 $\mathrm{mg}(47 \%) .{ }^{1} \mathrm{H} \mathrm{NMR}\left(500 \mathrm{MHz}, \mathrm{CDCl}_{3}\right)$ 8: 7.97-8.03 (m, 2H, ArH), 7.71-7.91 (m, 4H, ArH), 7.32-7.51 (m, 4H, ArH), 7.22 (d, $J=7.5$ $\mathrm{Hz}, 1 \mathrm{H}, \mathrm{ArH}), 7.02$ (d, $J=8.0 \mathrm{~Hz}, 1 \mathrm{H}, \mathrm{ArH}), 6.78-6.84(\mathrm{~m}, 2 \mathrm{H}$, $\operatorname{ArH}), 6.72(\mathrm{t}, J=7.4 \mathrm{~Hz}, 1 \mathrm{H}, \mathrm{ArH}), 6.53-6.67$ (m, 2H, ArH), 6.326.52 (m, 9H, ArH), 6.19 (d, $J=8.0 \mathrm{~Hz}, 1 \mathrm{H}, \mathrm{ArH}), 6.12$ (d, $J=8.0$ $\mathrm{Hz}, 1 \mathrm{H}, \mathrm{ArH}), 3.76$ (s, 3H, $\mathrm{CH}_{3}$ ), 2.09 (s 3H, $\left.\mathrm{CH}_{3}\right), 2.08$ (s, 3H, $\left.\mathrm{CH}_{3}\right) .{ }^{13} \mathrm{C}\left\{{ }^{1} \mathrm{H}\right\}$ NMR $\left(101 \mathrm{MHz}, \mathrm{CDCl}_{3}\right) \delta: 181.5,179.8,161.7$, 150.2.150.0, 149.2, 140.0, 139.5, 133.4, 131.5, 131.3, 131.0, 130.9, 130.0, 128.1, 128.0, 127.6, 127.4, 126.1, 125.6, 125.4, 123.6, 122.8, 122.4, 121.7, 121.1, 120.6, 119.7, 113.5, 55.36, 21.05, 20.89. Anal. Calcd for $\mathrm{C}_{48} \mathrm{H}_{37} \mathrm{IrN}_{6} \mathrm{OS}_{2}$ : C, 59.42; H, 3.84; N, 8.66. Found: C, 59.44; H, 3.84; N, 8.58.

$\operatorname{Ir}(\mathrm{bt})_{2}(\mathrm{Fzb})(3 \mathrm{~b})$. The title compound was prepared by the general method described above for complex $1 \mathbf{a} / 1 \mathbf{a}^{\prime}$, using $\left[\operatorname{Ir}(\mathrm{bt})_{2}(\mu\right.$ $\mathrm{Cl})]_{2}(50 \mathrm{mg}, 0.039 \mathrm{mmol})$ and $\mathrm{Fzb}(32 \mathrm{mg}, 0.81 \mathrm{mmol})$. The product was isolated as a mixture of isomers after column chromatography, and recrystallization of the product from a THF $/ \mathrm{MeOH}$ mixture afforded pure $3 \mathrm{~b}$ as a dark green solid. Yield: $39 \mathrm{mg}(50 \%) .{ }^{1} \mathrm{H}$

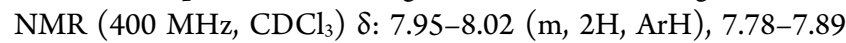
(m, 2H, ArH), $7.72(\mathrm{~d}, J=8.7 \mathrm{~Hz}, 2 \mathrm{H}, \operatorname{ArH}), 7.34-7.52(\mathrm{~m}, 4 \mathrm{H}$, $\operatorname{ArH}), 7.22-7.29$ (m, 1H, ArH), 7.11 (d, J=7.3 Hz, 1H, ArH), 6.82 (d, $J=8.7 \mathrm{~Hz}, 2 \mathrm{H}, \mathrm{ArH}), 6.72(\mathrm{t}, J=7.3 \mathrm{~Hz}, 1 \mathrm{H}, \mathrm{ArH}), 6.42-6.67$ (m, 7H, ArH), 6.09-6.27 (m, 6H, ArH), 3.78 (s, 3H, OCH $), 3.62$ (s, 3H, $\left.\mathrm{OCH}_{3}\right), 3.61\left(\mathrm{~s}, 3 \mathrm{H}, \mathrm{OCH}_{3}\right) .{ }^{13} \mathrm{C}\left\{{ }^{1} \mathrm{H}\right\} \mathrm{NMR}(151 \mathrm{MHz}$, $\left.\mathrm{CDCl}_{3}\right) \delta: 181.4,179.7,162.6,158.5,157.1,156.2,150.1,149.8$, $149.7,149.2,147.3,146.5,140.7,140.1,139.6,134.2,133.5,131.6$, $131.3,131.0,130.9,130.0,129.9,128.2,127.7,126.0,125.7,125.5$, 124.8, 123.7, 122.9, 122.4, 122.3, 121.7, 121.0, 120.5, 120.4, 113.6, 112.8, 112.6, 112.2, 55.55, 55.36, 55.12. Anal. Calcd for $\mathrm{C}_{48} \mathrm{H}_{37} \mathrm{IrN}_{6} \mathrm{O}_{3} \mathrm{~S}_{2}: \mathrm{C}, 57.53 ; \mathrm{H}, 3.72 ; \mathrm{N}, 8.39$. Found: C, 57.22; H, 3.57; N, 7.91.

$\operatorname{Ir}(\mathrm{bt})_{2}(\mathrm{Fze})(3 \mathrm{e})$. The title compound was prepared by the general method described above for complex $1 c^{\prime}$, using $\left[\operatorname{Ir}(b t)_{2}(\mu-C l)\right]_{2}$ $(100 \mathrm{mg}, 0.0771 \mathrm{mmol})$ and Fze $(39 \mathrm{mg}, 0.15 \mathrm{mmol})$. The product was obtained as a reddish green solid. Yield: $45 \mathrm{mg}$ (33\%). Elemental analysis returned high percentages for $\mathrm{C}$ and $\mathrm{H}$ and a low percentage for N, but the NMR spectra in Figures S36 and S37 indicate satisfactory bulk purity. ${ }^{1} \mathrm{H} \mathrm{NMR}\left(400 \mathrm{MHz}, \mathrm{CDCl}_{3}\right) \delta: 8.08(\mathrm{~d}, J=7.3 \mathrm{~Hz}$, $2 \mathrm{H}, \mathrm{ArH}), 7.80$ (d, $J=7.8 \mathrm{~Hz}, 1 \mathrm{H}, \mathrm{ArH}), 7.74(\mathrm{~d}, J=7.8 \mathrm{~Hz}, 1 \mathrm{H}$, $\operatorname{ArH}), 7.68$ (d, $J=8.2 \mathrm{~Hz}, 1 \mathrm{H}, \mathrm{ArH}), 7.38-7.47$ (m, 1H, ArH), 6.987.34 (m, 10H, ArH), 6.79-6.93 (m, 3H, ArH), 6.72 (d, $J=6.8 \mathrm{~Hz}$, $3 \mathrm{H}, \mathrm{ArH}), 6.49-6.54(\mathrm{~m}, 1 \mathrm{H}, \mathrm{ArH}), 6.44$ (d, $J=7.8 \mathrm{~Hz}, 1 \mathrm{H}, \mathrm{ArH})$, 2.33 (s, 3H, $\left.\mathrm{CH}_{3}\right), 2.24\left(\mathrm{~s}, 3 \mathrm{H}, \mathrm{CH}_{3}\right) .{ }^{13} \mathrm{C}\left\{{ }^{1} \mathrm{H}\right\} \mathrm{NMR}(151 \mathrm{MHz}$, $\left.\mathrm{CDCl}_{3}\right) \delta: 182.7,180.0,178.1,171.7,170.8,150.9,150.0,149.9$, 141.5, 139.9, 138.7, 138.2, 137.1, 133.0, 132.6, 131.2, 131.1, 130.8, 129.7, 128.5, 127.5, 127.4, 125.8, 125.6, 125.4, 125.3, 124.1, 122.8, 122.2, 121.9, 121.2, 120.8, 119.6, 119.4, 21.34, 21.23. Anal. Calcd for $\mathrm{C}_{42} \mathrm{H}_{30} \mathrm{IrN}_{7} \mathrm{~S}_{2}$ : C, 56.74; H, 3.40; N, 11.03. Found: C, 57.70; H, 3.93; $\mathrm{N}, 10.28$.

$\operatorname{Ir}(\mathrm{bt})_{2}$ (Fzf) (3f). The title compound was prepared by the general method described above for complex $1 c^{\prime}$, using $\left[\operatorname{Ir}(b t)_{2}(\mu-C l)\right]_{2}$ (100 mg, $0.0771 \mathrm{mmol})$ and Fzf (46 mg, $0.15 \mathrm{mmol})$. The product was isolated as a greenish brown solid. Yield: $51 \mathrm{mg}(38 \%) .{ }^{1} \mathrm{H}$ NMR $\left(500 \mathrm{MHz}, \mathrm{CDCl}_{3}\right)$ \&: 7.92-7.99 (m, 2H, ArH), 7.64-7.71 (m, 1H, ArH), 7.41-7.61 (m, 5H, ArH), 7.23-7.30 (m, 1H, ArH), 7.13 (d, J
$=7.8 \mathrm{~Hz}, 2 \mathrm{H}, \mathrm{ArH}), 7.01-7.08(\mathrm{~m}, 2 \mathrm{H}, \operatorname{ArH}), 6.95(\mathrm{~d}, J=8.2 \mathrm{~Hz}$, $2 \mathrm{H}, \mathrm{ArH}), 6.77-6.86$ ( $\mathrm{m}, 2 \mathrm{H}, \mathrm{ArH}), 6.69-6.76$ ( $\mathrm{m}, 3 \mathrm{H}, \mathrm{ArH}), 6.58-$ $6.66(\mathrm{~m}, 3 \mathrm{H}, \mathrm{ArH}), 6.05(\mathrm{dd}, J=7.8,22.9 \mathrm{~Hz}, 2 \mathrm{H}, \operatorname{ArH}) .{ }^{13} \mathrm{C}\left\{{ }^{1} \mathrm{H}\right\}$ $\mathrm{NMR}\left(126 \mathrm{MHz}, \mathrm{CDCl}_{3}\right) \delta: 181.6,180.1,155.6,154.8,152.7,149.2$, $148.4,146.2$, 139.7, 139.4, 139.1, 133.3, 132.0, 131.9, 131.5, 131.3, 131.1, 130.6, 129.1, 128.7, 126.7, 127.7, 126.4, 126.0, 123.7, 123.4, 123.3, 123.2, 122.2, 120.9, 119.2, 119.0, 118.9, 118.6, 114.2, 110.5, 108.7. Anal. Calcd for $\mathrm{C}_{42} \mathrm{H}_{24} \mathrm{IrN}_{9} \mathrm{~S}_{2} \cdot 0.25 \mathrm{C}_{4} \mathrm{H}_{8} \mathrm{O}_{2}: \mathrm{C}, 55.35 ; \mathrm{H}, 2.80$; N, 13.51. Found: C, 55.49; H, 2.67; N, 13.52 .

$\operatorname{Ir}(\text { piq })_{2}(\mathrm{Fza})(4 \mathrm{a})$. The title compound was prepared by the general method described above for complex $1 \mathrm{a} / 1 \mathrm{a}^{\prime}$, using $\left[\operatorname{Ir}(\mathrm{piq})_{2}(\mu-\right.$ $\mathrm{Cl})]_{2}(100 \mathrm{mg}, 0.0785 \mathrm{mmol})$ and Fza $(63 \mathrm{mg}, 0.16 \mathrm{mmol})$. The product was isolated as a mixture of isomer and recrystallized later $\left(\mathrm{CH}_{2} \mathrm{Cl}_{2} /\right.$ pentane) to get greenish blue solid. Yield: $74 \mathrm{mg}(48 \%)$. ${ }^{1} \mathrm{H} \mathrm{NMR}\left(400 \mathrm{MHz}, \mathrm{CDCl}_{3}\right) \delta: 8.65-8.74(\mathrm{~m}, 1 \mathrm{H}, \mathrm{ArH}), 8.58-8.64$ $(\mathrm{m}, 1 \mathrm{H}, \mathrm{ArH}), 8.46(\mathrm{~d}, J=6.4 \mathrm{~Hz}, 1 \mathrm{H}, \mathrm{ArH}), 8.32(\mathrm{~d}, J=6.4 \mathrm{~Hz}, 1 \mathrm{H}$, ArH), 7.79-7.93 (m, 5H, ArH), 7.58-7.78 (m, 5H, ArH), 7.37 (d, J $=6.4 \mathrm{~Hz}, 1 \mathrm{H}, \operatorname{ArH}), 7.30(\mathrm{~d}, J=6.4 \mathrm{~Hz}, 1 \mathrm{H}, \operatorname{ArH}), 6.78-6.88(\mathrm{~m}$, 5H, ArH), 6.45-6.64 (m, 5H, ArH), 6.31-6.43 (m, 3H, ArH), 6.21$6.28(\mathrm{~m}, 2 \mathrm{H}, \mathrm{ArH}), 6.14$ (d, $J=6.4 \mathrm{~Hz}, 1 \mathrm{H}, \mathrm{ArH}), 5.79$ (d, $J=8.0$ $\mathrm{Hz}, 1 \mathrm{H}, \mathrm{ArH}), 3.78\left(\mathrm{~s}, 3 \mathrm{H}, \mathrm{OCH}_{3}\right), 2.06\left(\mathrm{~s}, 3 \mathrm{H}, \mathrm{CH}_{3}\right), 2.02(\mathrm{~s}, 3 \mathrm{H}$, $\left.\mathrm{CH}_{3}\right) .{ }^{13} \mathrm{C}\left\{{ }^{1} \mathrm{H}\right\}$ NMR $\left(151 \mathrm{MHz}, \mathrm{CDCl}_{3}\right) \delta: 169.8,169.4,168.7$, $160.6,158.7,158.6,153.5,153.3,152.4,152.0,144.8,144.6,143.4$, $142.7,136.8,136.6,134.5,134.2,133.1,133.0,131.5,130.9,130.2$, $129.8,129.4,129.3,128.5,128.4,128.2$, 127.7, 127.4, 127.2, 127.1, 126.2, 123.6, 122.0, 121.0, 120.6, 120.2, 119.6, 119.1, 113.4, 55.37, 20.87, 20.82. Anal. Calcd for $\mathrm{C}_{52} \mathrm{H}_{41} \mathrm{IrN}_{6} \mathrm{O}: \mathrm{C}, 65.18 ; \mathrm{H}, 4.31 ; \mathrm{N}$, 8.77. Found: C, 65.15; H, 4.46; N, 8.50.

$\operatorname{Ir}$ (piq) $)_{2}$ (Fzf) (4f). The title compound was prepared by the general method described above for complex $1 \mathbf{c}^{\prime}$, using $\left[\operatorname{Ir}(\mathrm{piq})_{2}(\mu-\right.$ $\mathrm{Cl})]_{2}(75 \mathrm{mg}, 0.0589 \mathrm{mmol}$ ) and Fzf ( $46 \mathrm{mg}, 0.12 \mathrm{mmol}$ ). The product was isolated as a greenish brown solid. Yield: $60 \mathrm{mg}(56 \%) .{ }^{1} \mathrm{H}$ $\operatorname{NMR}\left(600 \mathrm{MHz}, \mathrm{CDCl}_{3}\right) \delta: 8.63(\mathrm{dd}, J=8.3,16.2 \mathrm{~Hz}, 2 \mathrm{H}, \mathrm{ArH})$, $8.10(\mathrm{~d}, J=6.2 \mathrm{~Hz}, 1 \mathrm{H}, \mathrm{ArH}), 8.03(\mathrm{~d}, J=6.2 \mathrm{~Hz}, 1 \mathrm{H}, \mathrm{ArH}), 7.93-$ $8.00(\mathrm{~m}, 2 \mathrm{H}, \mathrm{ArH}), 7.77-7.91(\mathrm{~m}, 5 \mathrm{H}, \mathrm{ArH}), 7.71(\mathrm{t}, J=7.9 \mathrm{~Hz}, 1 \mathrm{H}$, $\operatorname{ArH}), 7.52$ (d, $J=6.9 \mathrm{~Hz}, 1 \mathrm{H}, \operatorname{ArH}), 7.44$ (d, $J=6.2 \mathrm{~Hz}, 1 \mathrm{H}, \mathrm{ArH})$, 7.01-7.10 (m, 2H, ArH), 6.86-6.98 (m, 5H, ArH), 6.75-6.83 (m, $1 \mathrm{H}, \mathrm{ArH}), 6.68(\mathrm{t}, J=6.9 \mathrm{~Hz}, 1 \mathrm{H}, \mathrm{ArH}), 6.42-6.52(\mathrm{~m}, 3 \mathrm{H}, \mathrm{ArH})$, 6.04-6.10 (m, 1H, ArH), $5.82(\mathrm{~d}, J=8.3 \mathrm{~Hz}, 1 \mathrm{H}, \operatorname{ArH}) .{ }^{13} \mathrm{C}\left\{{ }^{1} \mathrm{H}\right\}$ $\mathrm{NMR}\left(151 \mathrm{MHz}, \mathrm{CDCl}_{3}\right) \delta: 169.1,168.1,156.0,155.2,153.9,149.6$, 144.7, 144.3, 142.3, 141.6, 138.4, 137.0, 136.9, 133.1, 132.1, 131.9, $131.7,131.5,131.2,130.3,130.0,129.8,129.0,128.9,127.8,127.5$, $126.9,126.8,126.2,126.1,122.9,122.6,121.7,121.5,121.2,119.1$, 118.7, 114.6, 110.2, 108.5. Anal. Calcd for $\mathrm{C}_{46} \mathrm{H}_{28} \mathrm{~N}_{9} \mathrm{Ir}: \mathrm{C}, 61.46 ; \mathrm{H}$, 3.14 ; N, 14.02. Found: C, 60.99; H, 3.18; N, 14.04.

X-ray Crystallography Details. Single crystals of $1 c^{\prime}, 1 d, 2 a, 2 c$, $2 \mathrm{~d}, 2 \mathrm{e}, 3 \mathrm{a}$, and $4 \mathrm{a}$ were grown by layering concentrated $\mathrm{CH}_{2} \mathrm{Cl}_{2}$ solutions with pentane or diffusing pentane into concentrated ethyl acetate solution. Crystals were mounted on a Bruker Apex II three-circle diffractometer using MoKa radiation $(\lambda=0.71073 \AA)$. The data were collected at 123(2) K and was processed and refined within the APEXII software. Structures were solved by direct methods in SHELXS and refined by standard difference Fourier techniques in the program SHELXL. ${ }^{68}$ Hydrogen atoms were placed in calculated positions using the standard riding model and refined isotropically. All non-hydrogen atoms were refined anisotropically. Crystallographic details are summarized in Tables S1-S3. 


\section{ASSOCIATED CONTENT}

\section{Supporting Information}

Crystallographic data summary, crystal structures of $1 \mathrm{~d}, 2 \mathrm{e}$, and $4 \mathrm{a}$, NMR spectra of all new compounds, additional UV-vis spectra, summary of solvatochromism experiments, additional cyclic voltammograms.

\section{Accession Codes}

CCDC 191336-191343 contain the supplementary crystallographic data for this paper. These data can be obtained free of charge via www.ccdc.cam.ac.uk/data_request/cif, or by emailing data_request@ccdc.cam.ac.uk, or by contacting The Cambridge Crystallographic Data Centre, 12 Union Road, Cambridge CB2 1EZ, UK; fax: +441223336033.

\section{AUTHOR INFORMATION}

\section{Corresponding Author}

*Email: tteets@uh.edu

\section{Author Contributions}

\$These authors contributed equally.

\section{ACKNOWLEDGMENT}

We acknowledge the University of Houston and the Welch Foundation (Grant no. E-1887) for funding. D. A. M. acknowledges the University of Houston Office of Undergraduate Research for support through the SURF program. N. A. B. acknowledges the Welch Summer Scholar Program for a research fellowship.

\section{REFERENCES}

(1) Kaim, W. Manifestations of Noninnocent Ligand Behavior. Inorg. Chem. 2011, 50 (20), 9752-9765. https://doi.org/10.1021/ic2003832.

(2) Kaim, W.; Schwederski, B. Non-Innocent Ligands in Bioinorganic Chemistry-An Overview. Coord. Chem. Rev. 2010, 254(13), 15801588. https://doi.org/10.1016/j.ccr.2010.01.009.

(3) Lyaskovskyy, V.; de Bruin, B. Redox Non-Innocent Ligands: Versatile New Tools to Control Catalytic Reactions. ACS Catal. 2012, 2 (2), 270-279. https://doi.org/10.1021/cs200660v.

(4) Luca, O. R.; Crabtree, R. H. Redox-Active Ligands in Catalysis. Chem. Soc. Rev. 2013, 42 (4), 1440-1459. https://doi.org/10.1039/C2CS35228A.

(5) Pavlova, I. S.; Pervova, I. G.; Belov, G. P.; Khasbiullin, I. I.; Slepukhin, P. A. Ethylene Oligomerization Mediated by Iron Formazanates and Organoaluminum Compounds. Pet. Chem. 2013, 53 (2), 127-133. https://doi.org/10.1134/S0965544113020072.

(6) Nineham, A. W. The Chemistry of Formazans and Tetrazolium Salts. Chem. Rev. 1955, 55 (2), 355-483. https://doi.org/10.1021/cr50002a004.

(7) Szymczyk, M.; El-Shafei, A.; Freeman, H. S. Design, Synthesis, and Characterization of New Iron-Complexed Azo Dyes. Dyes Pigments 2007, 72 (1), 8-15. https://doi.org/10.1016/j.dyepig.2005.07.009.

(8) Gruden, C. L.; Fevig, S.; Abu-Dalo, M.; Hernandez, M. 5-Cyano2,3-Ditolyl Tetrazolium Chloride (CTC) Reduction in a Mesophilic Anaerobic Digester: Measuring Redox Behavior, Differentiating Abiotic Reduction, and Comparing FISH Response as an Activity Indicator. J. Microbiol. Methods 2003, 52 (1), 59-68. https://doi.org/10.1016/S01677012(02)00134-3.

(9) Frederiks, W. M.; Marle, J. van; Oven, C. van; Comin-Anduix, B.; Cascante, M. Improved Localization of Glucose-6-Phosphate Dehydrogenase Activity in Cells with 5-Cyano-2, 3-Ditolyl-Tetrazolium Chloride as Flu- orescent Redox Dye Reveals Its Cell Cycle-Dependent Regulation.J. Histochem. Cytochem. 2006, 54 (1), 47-52. https://doi.org/10.1369/jhc.5A6663.2005.

(10) Hunter, L.; Roberts, C. B. 145. The Associating Effect of the Hydrogen Atom. Part IX. The N-H-N Bond. Virtual Tautomerism of the Formazyl Compounds. J. Chem. Soc. Resumed 1941, O (0), 820-823. https://doi.org/10.1039/JR9410000820.

(11) Irving, H.; Gill, J. B.; Cross, W. R. 423. The Structure of Some Di(3-Methyl-1,5-Diarylformazyl)-Nickel(II) Complexes. J. Chem. Soc. Resumed 1960, $O$ (0), 2087-2095. https://doi.org/10.1039/JR9600002087.

(12) Budesinsky, B.; Svecova, J. Hydrogen and Metal Complexes of Some 3-Cyanoformazans. Inorg. Chem. 1971, 10 (2), 313-317. https://doi.org/10.1021/ic50096a019.

(13) Siedle, A. R.; Pignolet, L. H. Formazanylpalladium Compounds. Synthesis and Structure of Bis(1,3,5-Tri-p-Tolylformazanyl)Palladium. In-

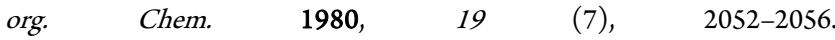
https://doi.org/10.1021/ic50209a043.

(14) Zarkesh, R. A.; Ichimura, A. S.; Monson, T. C.; Tomson, N. C.; Anstey, M. R. Voltage Clustering in Redox-Active Ligand Complexes: Mitigating Electronic Communication through Choice of Metal Ion. Dalton $\begin{array}{llll}\text { Trans. } & 2016, & 45 & \text { (24), }\end{array}$ https://doi.org/10.1039/C6DT00422A.

(15) Ketterer, N. A.; Fan, H.; Blackmore, K. J.; Yang, X.; Ziller, J. W.; Baik, M.-H.; Heyduk, A. F. П•- $-\pi$ Bonding Interactions Generated by Halogen Oxidation of Zirconium(IV) Redox-Active Ligand Complexes. J. Am. Chem. Soc. 2008, $130 \quad$ (13), 4364-4374. https://doi.org/10.1021/ja077337m.

(16) Mandal, A.; Schwederski, B.; Fiedler, J.; Kaim, W.; Lahiri, G. K. Evidence for Bidirectional Noninnocent Behavior of a Formazanate Ligand in Ruthenium Complexes. Inorg. Chem. 2015, 54 (16), 8126-8135. https://doi.org/10.1021/acs.inorgchem.5b01408.

(17) Chang, M.-C.; Dann, T.; Day, D. P.; Lutz, M.; Wildgoose, G. G.; Otten, E. The Formazanate Ligand as an Electron Reservoir: Bis(Formazanate) Zinc Complexes Isolated in Three Redox States. Angew. Chem. Int. Ed. 2014, 53 (16), 4118-4122. https://doi.org/10.1002/anie.201309948.

(18) Singha Hazari, A.; Mandal, A.; Beyer, K.; Paretzki, A.; Kaim, W.; Lahiri, G. K. Metal-Metal Bridging Using the DPPP Dye System: Electronic Configurations within Multiple Redox Series. Inorg. Chem. 2017, 56 (5), 2992-3004. https://doi.org/10.1021/acs.inorgchem.6b03112.

(19) Gilroy, J. B.; Patrick, B. O.; McDonald, R.; Hicks, R. G. Transition Metal Complexes of 3-Cyano- and 3-Nitroformazans. Inorg. Chem. 2008, 47(4), 1287-1294. https://doi.org/10.1021/ic7019846.

(20) Hong, S.; Gupta, A. K.; Tolman, W. B. Intermediates in Reactions of Copper(I) Complexes with N-Oxides: From the Formation of Stable Adducts to Oxo Transfer. Inorg. Chem. 2009, 48 (14), 6323-6325. https://doi.org/10.1021/ic900435p.

(21) Hong, S.; Hill, L. M. R.; Gupta, A. K.; Naab, B. D.; Gilroy, J. B.; Hicks, R. G.; Cramer, C. J.; Tolman, W. B. Effects of Electron-Deficient $\beta$ Diketiminate and Formazan Supporting Ligands on Copper(I)-Mediated Dioxygen Activation. Inorg. Chem. 2009, 48 (10), 4514-4523. https://doi.org/10.1021/ic9002466.

(22) Broere, D. L. J.; Mercado, B. Q.; Bill, E.; Lancaster, K. M.; Sproules, S.; Holland, P. L. Alkali Cation Effects on Redox-Active Formazanate Ligands in Iron Chemistry. Inorg. Chem. 2018. https://doi.org/10.1021/acs.inorgchem.8b00226.

(23) Broere, D. L. J.; Mercado, B. Q.; Lukens, J. T.; Vilbert, A. C.; Banerjee, G.; Lant, H. M. C.; Lee, S. H.; Bill, E.; Sproules, S.; Lancaster, K. M.; et al. Reversible Ligand-Centered Reduction in Low-Coordinate Iron Formazanate Complexes. Chem. - Eur. J. 2018, 24 (37), 9417-9425. https://doi.org/10.1002/chem.201801298.

(24) Milocco, F.; Demeshko, S.; Meyer, F.; Otten, E. Ferrate( II ) Complexes with Redox-Active Formazanate Ligands. Dalton Trans. 2018, 47(26), 8817-8823. https://doi.org/10.1039/C8DT01597J.

(25) Chang, M.-C.; Roewen, P.; Travieso-Puente, R.; Lutz, M.; Otten, E. Formazanate Ligands as Structurally Versatile, Redox-Active Analogues 
of $\beta$-Diketiminates in Zinc Chemistry. Inorg. Chem. 2015, 54 (1), 379-388. https://doi.org/10.1021/ic5025873.

(26) Chang, M.-C.; Dann, T.; Day, D. P.; Lutz, M.; Wildgoose, G. G.; Otten, E. The Formazanate Ligand as an Electron Reservoir: Bis(Formazanate) Zinc Complexes Isolated in Three Redox States. Angew. Chem. Int. Ed. 2014, 53 (16), 4118-4122. https://doi.org/10.1002/anie.201309948.

(27) Travieso-Puente, R.; Broekman, J. O. P.; Chang, M.-C.; Demeshko, S.; Meyer, F.; Otten, E. Spin-Crossover in a Pseudo-Tetrahedral Bis(Formazanate) Iron Complex. J. Am. Chem. Soc. 2016, 138 (17), 55035506. https://doi.org/10.1021/jacs.6b01552.

(28) Protasenko, N. A.; Poddel'sky, A. I.; Bogomyakov, A. S.; Fukin, G. K.; Cherkasov, V. K. Heteroligand O-Semiquinonato-Formazanato Cobalt Complexes. Inorg. Chem. 2015, 54 (13), 6078-6080. https://doi.org/10.1021/acs.inorgchem.5b00912.

(29) Protasenko, N. A.; Poddel'sky, A. I.; Bogomyakov, A. S.; Starikov, A. G.; Smolyaninov, I. V.; Berberova, N. T.; Fukin, G. K.; Cherkasov, V. K. The Chemical and Electrochemical Reduction of Heteroligand O-Semiquinonato-Formazanato Cobalt Complexes. Inorganica Chim. Acta 2019, 489, 1-7. https://doi.org/10.1016/j.ica.2019.02.002.

(30) Maar, R. R.; Catingan, S. D.; Staroverov, V. N.; Gilroy, J. B. Formazanate Complexes of Hypervalent Group 14 Elements as Precursors to Electronically Stabilized Radicals. Angew. Chem. Int. Ed. 2018, 57 (31), 9870-9874. https://doi.org/10.1002/anie.201806097.

(31) Barbon, S. M.; Reinkeluers, P. A.; Price, J. T.; Staroverov, V. N.; Gilroy, J. B. Structurally Tunable 3-Cyanoformazanate Boron Difluoride Dyes. Chem. - Eur. J. 2014, 20 (36), 11340-11344. https://doi.org/10.1002/chem.201404297.

(32) Barbon, S. M.; Staroverov, V. N.; Gilroy, J. B. Effect of Extended $\pi$ Conjugation on the Spectroscopic and Electrochemical Properties of Boron Difluoride Formazanate Complexes. J. Org. Chem. 2015, 80 (10), 5226-5235. https://doi.org/10.1021/acs.joc.5b00620.

(33) Maar, R. R.; Barbon, S. M.; Sharma, N.; Groom, H.; Luyt, L. G.; Gilroy, J. B. Evaluation of Anisole-Substituted Boron Difluoride Formazanate Complexes for Fluorescence Cell Imaging. Chem. - Eur.J.2015, 21 (44), 15589-15599. https://doi.org/10.1002/chem.201502821.

(34) Chang, M.-C.; Chantzis, A.; Jacquemin, D.; Otten, E. Boron Difluorides with Formazanate Ligands: Redox-Switchable Fluorescent Dyes with Large Stokes Shifts. Dalton Trans. 2016, 45 (23), 9477-9484. https://doi.org/10.1039/C6DT01226D.

(35) Chang, M.-C.; Otten, E. Synthesis and Ligand-Based Reduction Chemistry of Boron Difluoride Complexes with Redox-Active Formazanate Ligands. Chem. Commun. 2014, 50 (56), 7431-7433. https://doi.org/10.1039/C4CC03244F.

(36) Mondol, R.; Snoeken, D. A.; Chang, M.-C.; Otten, E. Stable, Crystalline Boron Complexes with Mono-, Di- and Trianionic Formazanate Ligands. Chem. Commun. 2017, 53 (3), 513-516. https://doi.org/10.1039/C6CC08166E.

(37) Barbon, S. M.; Novoa, S.; Bender, D.; Groom, H.; Luyt, L. G.; Gilroy, J. B. Copper-Assisted Azide-Alkyne Cycloaddition Chemistry as a Tool for the Production of Emissive Boron Difluoride 3-Cyanoformazanates. Org. Chem. Front. 2017, 4 (2), 178-190. https://doi.org/10.1039/C6QO00640J.

(38) Hesari, M.; Barbon, S. M.; Staroverov, V. N.; Ding, Z.; Gilroy, J. B. Efficient Electrochemiluminescence of a Readily Accessible Boron Difluoride Formazanate Dye. Chem. Commun. 2015, 51 (18), 3766-3769. https://doi.org/10.1039/C4CC10038G.

(39) Hesari, M.; Barbon, S. M.; Mendes, R. B.; Staroverov, V. N.; Ding, Z.; Gilroy, J. B. Structural Tuning of Boron Difluoride Formazanate Electrochemiluminescence Mediated by Tri- $n$-Propylamine. J. Phys. $\begin{array}{lllll}\text { Chem. } & C & 2018, & 122 & \text { (2), 1258-1266. }\end{array}$ https://doi.org/10.1021/acs.jpcc.7b10246.

(40) Dhindsa, J. S.; Maar, R. R.; Barbon, S. M.; Olivia Avilés, M.; Powell, Z. K.; Lagugné-Labarthet, F.; Gilroy, J. B. A $\pi$-Conjugated Inorganic Polymer Constructed from Boron Difluoride Formazanates and Platinum( II )
Diynes. Chem. Commun. 2018, 54 (50), 6899-6902. https://doi.org/10.1039/C8CC02424C.

(41) Novoa, S.; Paquette, J. A.; Barbon, S. M.; Maar, R. R.; Gilroy, J. B. Side-Chain Boron Difluoride Formazanate Polymers via Ring-Opening Metathesis Polymerization. J. Mater. Chem. C 2016, 4 (18), 3987-3994. https://doi.org/10.1039/C5TC03287C.

(42) Chang, M.-C.; Otten, E. Reduction of (Formazanate)Boron Difluoride Provides Evidence for an N-Heterocyclic B(I) Carbenoid Intermediate. Inorg. Chem. 2015, 54 (17), 8656-8664. https://doi.org/10.1021/acs.inorgchem.5b01287.

(43) Barbon, S. M.; Staroverov, V. N.; Gilroy, J. B. Structurally Diverse Boron-Nitrogen Heterocycles from an N2O23- Formazanate Ligand. Angew. Chem. Int. Ed. 2017, 56 (28), 8173-8177. https://doi.org/10.1002/anie.201704285.

(44) Meriwether, L. S.; Breitner, E. C.; Sloan, C. L. The Photochromism of Metal Dithizonates. J. Am. Chem. Soc. 1965, 87 (20), 4441-4448. https://doi.org/10.1021/ja00948a006.

(45) Petersen, R. L.; McFarland, J. T.; Watters, K. L. Resonance Raman Study of Metal-Formazans: A Model for Complexes of Metalloenzymes with Chelate Inhibitors. Bioinorg. Chem. 1978, 9 (4), 355-367. https://doi.org/10.1016/S0006-3061(00)80030-7.

(46) Zhang, H.-Y.; Sun, W.-X.; Wu, Q.-A.; Zhangb, H.-Q.; Chen, Y.Y. Study on 1,5-Bis(2-Carboxyphenyl)-3-Phenylformazan and Its Complexes. Synth. React. Inorg. Met.-Org. Chem. 2000, 30 (4), 571-582. https://doi.org/10.1080/00945710009351783.

(47) Bait, S.; Meuldijk, J.; Renkema, W. E. Square Planar Complexes of Nickel(II), Palladium(II) and Platinum(II) with 1-(2-Hydroxyphenyl)3,5-Diphenylformazan. Transit. Met. Chem. 1980, 5 (1), 357-361. https://doi.org/10.1007/BF01396960.

(48) Balt, S.; Meuldijk, J. Solvent Effects in Square Planar Complexes: Kinetics of Substitution at 1-(2-Hydroxyphenyl)-3,5-(Diphenylformazanato)-Platinum(II) Complexes. Inorganica Chim. Acta 1981, 47, $217-$ 223. https://doi.org/10.1016/S0020-1693(00)89333-0.

(49) Kabir, E.; Wu, C.-H.; Wu, J. I.-C.; Teets, T. S. Heteroleptic Complexes of Cyclometalated Platinum with Triarylformazanate Ligands. Inorg. Chem. 2016, 55 (2), 956-963. https://doi.org/10.1021/acs.inorgchem.5b02595.

(50) Kabir, E.; Patel, D.; Clark, K.; Teets, T. S. Spectroscopic and Electrochemical Properties of Electronically Modified Cycloplatinated Formazanate Complexes. Inorg. Chem. 2018, 57 (17), 10906-10917. https://doi.org/10.1021/acs.inorgchem.8b01543.

(51) Mu, G.; Cong, L.; Wen, Z.; Wu, J. I.-C.; Kadish, K. M.; Teets, T. S. Homoleptic Platinum Azo-Iminate Complexes via Hydrogenative Cleavage of Formazans. Inorg. Chem. 2018, 57 (15), 9468-9477. https://doi.org/10.1021/acs.inorgchem.8b01456.

(52) Tsuboyama, A.; Iwawaki, H.; Furugori, M.; Mukaide, T.; Kamatani, J.; Igawa, S.; Moriyama, T.; Miura, S.; Takiguchi, T.; Okada, S.; et al. Homoleptic Cyclometalated Iridium Complexes with Highly Efficient Red Phosphorescence and Application to Organic Light-Emitting Diode. J. Am. Chem. Soc. 2003, 125 (42), 12971-12979. https://doi.org/10.1021/ja034732d.

(53) Longhi, E.; Cola, L. D. Iridium(III) Complexes for OLED Application. In Iridium(III) in Optoelectronic and Photonics Applications; John Wiley \& Sons, Ltd, 2017; pp 205-274. https://doi.org/10.1002/9781119007166.ch6.

(54) Tamayo, A. B.; Garon, S.; Sajoto, T.; Djurovich, P. I.; Tsyba, I. M.; Bau, R.; Thompson, M. E. Cationic Bis-Cyclometalated Iridium(III) Diimine Complexes and Their Use in Efficient Blue, Green, and Red Electroluminescent Devices. Inorg. Chem. 2005, 44 (24), 8723-8732. https://doi.org/10.1021/ic050970t.

(55) Lowry, M. S.; Goldsmith, J. I.; Slinker, J. D.; Rohl, R.; Pascal, R. A.; Malliaras, G. G.; Bernhard, S. Single-Layer Electroluminescent Devices and Photoinduced Hydrogen Production from an Ionic Iridium(III) Complex. Chem. Mater. 2005, 17 (23), 5712-5719. https://doi.org/10.1021/cm051312+. 
(56) Lo, K. K.-W.; Ng, D. C.-M.; Chung, C.-K. First Examples of Luminescent Cyclometalated Iridium(III) Complexes as Labeling Reagents for Biological Substrates. Organometallics 2001, 20 (24), 4999-5001. https://doi.org/10.1021/om010652b.

(57) Lo, K. K.-W.; Chung, C.-K.; Lee, T. K.-M.; Lui, L.-H.; Tsang, K. H.-K.; Zhu, N. New Luminescent Cyclometalated Iridium(III) Diimine Complexes as Biological Labeling Reagents. Inorg. Chem. 2003, 42 (21), 6886-6897. https://doi.org/10.1021/ic0346984.

(58) Milocco, F.; Vries, F. de; Dall'Anese, A.; Rosar, V.; Zangrando, E.; Otten, E.; Milani, B. Palladium Alkyl Complexes with a Formazanate Ligand: Synthesis, Structure and Reactivity. Dalton Trans. 2018, 47 (41), 14445-14451. https://doi.org/10.1039/C8DT03130D.

(59) Cordero, B.; Gómez, V.; Platero-Prats, A. E.; Revés, M.; Echeverría, J.; Cremades, E.; Barragán, F.; Alvarez, S. Covalent Radii Revisited. Dalton Trans. 2008, No. 21, 2832-2838. https://doi.org/10.1039/b801115j.

(60) Radwan, Y. K.; Maity, A.; Teets, T. S. Manipulating the Excited States of Cyclometalated Iridium Complexes with $\beta$-Ketoiminate and $\beta$ Diketiminate Ligands. Inorg. Chem. 2015, 54 (14), 7122-7131. https://doi.org/10.1021/acs.inorgchem.5b01401.

(61) Lai, P.-N.; Brysacz, C. H.; Alam, M. K.; Ayoub, N. A.; Gray, T. G.; Bao, J.; Teets, T. S. Highly Efficient Red-Emitting Bis-Cyclometalated Iridium Complexes. J. Am. Chem. Soc. 2018, 140 (32), 10198-10207. https://doi.org/10.1021/jacs.8b04841.

(62) Lamansky, S.; Djurovich, P.; Murphy, D.; Abdel-Razzaq, F.; Kwong, R.; Tsyba, I.; Bortz, M.; Mui, B.; Bau, R.; Thompson, M. E. Synthesis and Characterization of Phosphorescent Cyclometalated Iridium Complexes. Inorg. Chem. 2001, 40, 1704-1711. https://doi.org/10.1021/ic0008969.

(63) Li, J.; Djurovich, P. I.; Alleyne, B. D.; Yousufuddin, M.; Ho, N. N.; Thomas, J. C.; Peters, J. C.; Bau, R.; Thompson, M. E. Synthetic Control of Excited-State Properties in Cyclometalated Ir(III) Complexes Using Ancillary Ligands. Inorg. Chem. 2005, 44 (6), 1713-1727. https://doi.org/10.1021/ic048599h.

(64) Pangborn, A. B.; Giardello, M. A.; Grubbs, R. H.; Rosen, R. K.; Timmers, F. J. Safe and Convenient Procedure for Solvent Purification. Organometallics 1996, 15 (5), 1518-1520. https://doi.org/10.1021/om9503712.

(65) Gilroy, J. B.; McKinnon, S. D. J.; Koivisto, B. D.; Hicks, R. G. Electrochemical Studies of Verdazyl Radicals. Org. Lett. 2007, 9 (23), 4837-4840. https://doi.org/10.1021/ol702163a.

(66) Nonoyama, M. Benzo[h]Quinolin-10-Yl-N Iridium(III) Complexes. Bull. Chem. Soc. Jpn. 1974, 47 (3), 767-768. https://doi.org/10.1246/bcsj.47.767.

(67) Peng, T.; Yang, Y.; Liu, Y.; Ma, D.; Hou, Z.; Wang, Y. A Phosphorescent Material with High and Balanced Carrier Mobility for Efficient OLEDs. Chem. Commun. 2011, 47 (11), 3150-3152. https://doi.org/10.1039/C0CC04684A.

(68) Sheldrick, G. M. A Short History of SHELX. Acta Crystallogr. A 2008, 64 (1), 112-122. https://doi.org/10.1107/S0108767307043930. 
SYNOPSIS TOC : Bis-cyclometalated iridium(III) formazanate complexes are presented. A total of 18 new compounds are described, characterized by cyclic voltammetry and UV-vis absorption spectroscopy. Structural characterization in the solid-state by X-ray crystallography and in solution by multinuclear NMR reveal two distinct binding modes of the chelating formazanate ligand.

Insert Table of Contents artwork here

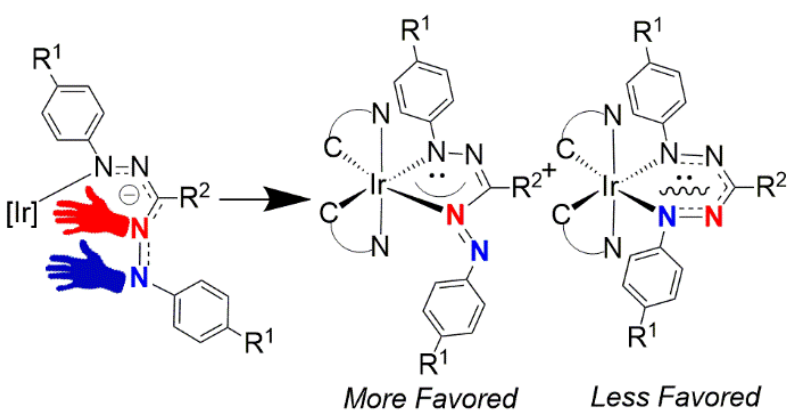




\title{
Supporting Information for
}

\author{
Evanta Kabir, Ge Mu, David A. Momtaz, Noah A. Bryce, and Thomas S. Teets* \\ Department of Chemistry, University of Houston, \\ 3585 Cullen Blvd. Room 112, Houston, TX 77204-5003 \\ email: tteets@uh.edu
}

\begin{tabular}{|l|l|}
\hline Index & Page \\
\hline X-ray crystallographic summary tables & S2-S4 \\
\hline Additional X-ray crystal structures & S5 \\
\hline NMR Spectra of complexes & S6-S26 \\
\hline Electronic absorption spectra & S27 \\
\hline Solvent-dependent absorption spectra of complexes 1-4 and summary table & S28-S31 \\
\hline Additional cyclic voltammograms of complexes & S32-S33 \\
\hline
\end{tabular}


Table S1. Summary of crystallographic data for $\mathbf{1} \mathbf{c}^{\prime}, \mathbf{1 d}$, and $\mathbf{2 a}$.

\begin{tabular}{|c|c|c|c|}
\hline & $\mathbf{1} \mathbf{c}^{\prime} \cdot 0.5 \mathrm{CH}_{2} \mathrm{Cl}_{2}$ & $\mathbf{1 d} \cdot \mathrm{CH}_{2} \mathrm{Cl}_{2}$ & $2 a$ \\
\hline $\mathrm{CCDC}$ & 191336 & 191337 & 191338 \\
\hline \multicolumn{4}{|l|}{ Crystal data } \\
\hline Chemical formula & $\mathrm{C}_{44.50} \mathrm{H}_{35} \mathrm{ClIrN}_{7}$ & $\mathrm{C}_{45} \mathrm{H}_{33} \mathrm{Cl}_{2} \mathrm{IrN}_{8}$ & $\mathrm{C}_{44} \mathrm{H}_{33} \mathrm{~F}_{4} \mathrm{IrN}_{6} \mathrm{O}$ \\
\hline$M_{\mathrm{r}}$ & 895.44 & 948.89 & 929.96 \\
\hline $\begin{array}{l}\text { Crystal system, space } \\
\text { group }\end{array}$ & Monoclinic, $P 2_{1} / c$ & Triclinic, $P \overline{1}$ & Monoclinic, $P 2_{1} / c$ \\
\hline$a, b, c(\AA)$ & $\begin{array}{l}8.3278(11), 13.6396 \\
(18), 32.927(4)\end{array}$ & $\begin{array}{l}7.800(4), 13.666(7) \\
19.338(10)\end{array}$ & $\begin{array}{l}13.819(2), 17.291(3), \\
31.180(5)\end{array}$ \\
\hline$\alpha, \beta, \gamma\left({ }^{\circ}\right)$ & $90,94.820(2), 90$ & $\begin{array}{l}94.197(6), 100.672 \\
(6), 100.065(6)\end{array}$ & $90,99.037$ (2), 90 \\
\hline$V\left(\AA^{3}\right)$ & $3726.9(9)$ & $1982.6(18)$ & $7358(2)$ \\
\hline$Z$ & 4 & 2 & 8 \\
\hline$\mu\left(\mathrm{mm}^{-1}\right)$ & 3.70 & 3.55 & 3.70 \\
\hline Crystal size (mm) & $0.25 \times 0.12 \times 0.05$ & $0.25 \times 0.10 \times 0.08$ & $0.39 \times 0.14 \times 0.12$ \\
\hline \multicolumn{4}{|l|}{ Data collection } \\
\hline$T_{\min }, T_{\max }$ & $0.553,0.746$ & $0.602,0.745$ & $0.510,0.746$ \\
\hline $\begin{array}{l}\text { No. of measured, } \\
\text { independent and } \\
\text { observed }[I>2 \sigma(I)] \\
\text { reflections }\end{array}$ & $21621,8442,7359$ & $22406,7691,7169$ & $42064,16616,15080$ \\
\hline$R_{\text {int }}$ & 0.020 & 0.036 & 0.019 \\
\hline$(\sin \theta / \lambda)_{\max }\left(\AA^{-1}\right)$ & 0.649 & 0.617 & 0.649 \\
\hline \multicolumn{4}{|l|}{ Refinement } \\
\hline $\begin{array}{l}R\left[F^{2}>2 \sigma\left(F^{2}\right)\right] \\
w R\left(F^{2}\right), S\end{array}$ & $0.029,0.073,1.06$ & $0.062,0.162,1.08$ & $0.031,0.112,1.20$ \\
\hline No. of reflections & 8442 & 7691 & 16616 \\
\hline No. of parameters & 517 & 506 & 1015 \\
\hline \multirow[t]{2}{*}{ No. of restraints } & 642 & 511 & 0 \\
\hline & $\begin{array}{l}w=1 /\left[\sigma^{2}\left(F_{\mathrm{o}}^{2}\right)+\right. \\
(0.0277 P)^{2}+ \\
10.5019 P] \\
\text { where } P=\left(F_{\mathrm{o}}^{2}+\right. \\
\left.2 F_{\mathrm{c}}^{2}\right) / 3\end{array}$ & $\begin{array}{l}w=1 /\left[\sigma^{2}\left(F_{\mathrm{o}}^{2}\right)+\right. \\
(0.0734 P)^{2}+ \\
44.1129 P] \\
\text { where } P=\left(F_{\mathrm{o}}^{2}+\right. \\
\left.2 F_{\mathrm{c}}^{2}\right) / 3\end{array}$ & $\begin{array}{l}w=1 /\left[\sigma^{2}\left(F_{\mathrm{o}}^{2}\right)+\right. \\
\left.(0.0591 P)^{2}+21.696 P\right] \\
\text { where } P=\left(F_{\mathrm{o}}^{2}+\right. \\
\left.2 F_{\mathrm{c}}^{2}\right) / 3\end{array}$ \\
\hline$\Delta \rho_{\max }, \Delta \rho_{\min }\left(\mathrm{e} \AA^{-3}\right)$ & $1.34,-1.78$ & $7.89,-3.90$ & $3.07,-1.83$ \\
\hline
\end{tabular}


Table S2. Summary of crystallographic data for $\mathbf{2 c}, \mathbf{2 d}$ and $\mathbf{2 e .}$

\begin{tabular}{|c|c|c|c|}
\hline & $2 c$ & $2 d$ & $2 e$ \\
\hline $\mathrm{CCDC}$ & 191339 & 191340 & 191341 \\
\hline \multicolumn{4}{|l|}{ Crystal data } \\
\hline Chemical formula & $\mathrm{C}_{44} \mathrm{H}_{30} \mathrm{~F}_{4} \mathrm{IrN}_{7}$ & $\mathrm{C}_{44} \mathrm{H}_{27} \mathrm{~F}_{4} \mathrm{IrN}_{8}$ & $\mathrm{C}_{38} \mathrm{H}_{26} \mathrm{~F}_{4} \mathrm{IrN} \mathrm{N}_{7}$ \\
\hline$M_{\mathrm{r}}$ & 924.95 & 935.93 & 848.86 \\
\hline $\begin{array}{l}\text { Crystal system, space } \\
\text { group }\end{array}$ & Triclinic, $P \overline{1}$ & Monoclinic, $P 2{ }_{1} / c$ & Monoclinic, $C 2 / c$ \\
\hline$a, b, c(\AA)$ & $\begin{array}{l}11.8119(12), 11.9432 \\
(12), 14.7901(15)\end{array}$ & $\begin{array}{l}17.897(5), 8.693(3), \\
23.444(7)\end{array}$ & $\begin{array}{l}26.377(4), 24.953(4), \\
12.001(2)\end{array}$ \\
\hline$\alpha, \beta, \gamma\left(^{\circ}\right)$ & $\begin{array}{l}108.9555(12), 91.9403 \\
(13), 109.1664(13)\end{array}$ & $90,91.553$ (4), 90 & $90,114.140(2), 90$ \\
\hline$V\left(\AA^{3}\right)$ & $1840.7(3)$ & $3646.1(18)$ & $7208(2)$ \\
\hline$Z$ & 2 & 4 & 8 \\
\hline$\mu\left(\mathrm{mm}^{-1}\right)$ & 3.69 & 3.73 & 3.76 \\
\hline Crystal size (mm) & $0.40 \times 0.26 \times 0.16$ & $0.21 \times 0.10 \times 0.05$ & $0.47 \times 0.09 \times 0.07$ \\
\hline \multicolumn{4}{|l|}{ Data collection } \\
\hline$T_{\min }, T_{\max }$ & $0.602,0.746$ & $0.562,0.746$ & $0.491,0.746$ \\
\hline $\begin{array}{l}\text { No. of measured, } \\
\text { independent and } \\
\text { observed }[I>2 \sigma(I)] \\
\text { reflections }\end{array}$ & $10228,7383,7003$ & $22114,8437,7123$ & $22704,8354,6955$ \\
\hline$R_{\text {int }}$ & 0.014 & 0.039 & 0.027 \\
\hline$(\sin \theta / \lambda)_{\max }\left(\AA^{-1}\right)$ & 0.625 & 0.652 & 0.653 \\
\hline \multicolumn{4}{|l|}{ Refinement } \\
\hline $\begin{array}{l}R\left[F^{2}>2 \sigma\left(F^{2}\right)\right], \\
w R\left(F^{2}\right), S\end{array}$ & $0.026,0.063,1.05$ & $0.028,0.058,1.01$ & $0.053,0.139,1.08$ \\
\hline No. of reflections & 7383 & 8437 & 8354 \\
\hline No. of parameters & 526 & 515 & 452 \\
\hline \multirow[t]{2}{*}{ No. of restraints } & 100 & 0 & 465 \\
\hline & $\begin{array}{l}w=1 /\left[\sigma^{2}\left(F_{\mathrm{o}}^{2}\right)+\right. \\
\left.(0.029 P)^{2}+3.7672 P\right] \\
\text { where } P=\left(F_{\mathrm{o}}^{2}+\right. \\
\left.2 F_{\mathrm{c}}^{2}\right) / 3\end{array}$ & $\begin{array}{l}w=1 /\left[\sigma^{2}\left(F_{\mathrm{o}}^{2}\right)+\right. \\
\left.(0.0189 P)^{2}\right] \\
\text { where } P=\left(F_{\mathrm{o}}^{2}+\right. \\
\left.2 F_{\mathrm{c}}^{2}\right) / 3\end{array}$ & $\begin{array}{l}w=1 /\left[\sigma^{2}\left(F_{\mathrm{o}}{ }^{2}\right)+\right. \\
(0.0546 P)^{2}+ \\
83.6126 P] \\
\text { where } P=\left(F_{\mathrm{o}}{ }^{2}+\right. \\
\left.2 F_{\mathrm{c}}{ }^{2}\right) / 3\end{array}$ \\
\hline$\Delta \rho_{\max }, \Delta \rho_{\min }\left(\mathrm{e} \AA^{-3}\right)$ & $2.07,-0.93$ & $0.95,-0.52$ & $4.42,-3.37$ \\
\hline
\end{tabular}


Table S3. Summary of crystallographic data for $\mathbf{3 a}$ and $\mathbf{4 a}$.

\begin{tabular}{|c|c|c|}
\hline & $\mathbf{3 a} \cdot \mathrm{MeOH}$ & $4 \mathbf{a} \cdot \mathrm{CH}_{2} \mathrm{Cl}_{2}$ \\
\hline $\mathrm{CCDC}$ & 191342 & 191343 \\
\hline \multicolumn{3}{|l|}{ Crystal data } \\
\hline Chemical formula & $\mathrm{C}_{49} \mathrm{H}_{41} \mathrm{IrN}_{6} \mathrm{O}_{2} \mathrm{~S}_{2}$ & $\mathrm{C}_{53} \mathrm{H}_{43} \mathrm{Cl}_{2} \mathrm{IrN}_{6} \mathrm{O}$ \\
\hline$M_{\mathrm{r}}$ & 1002.20 & 1043.03 \\
\hline$a, b, c(\AA)$ & $\begin{array}{l}11.1354(5), 11.9908(5), 16.0273 \\
(7)\end{array}$ & $\begin{array}{l}12.4439(8), 13.9851(9), 14.2806 \\
(10)\end{array}$ \\
\hline$\alpha, \beta, \gamma\left({ }^{\circ}\right)$ & $91.100(1), 99.67,99.502(1)$ & $114.817(1), 96.371(1), 99.887(1)$ \\
\hline$V\left(\AA^{3}\right)$ & $2078.23(16)$ & $2175.2(3)$ \\
\hline$\mu\left(\mathrm{mm}^{-1}\right)$ & 3.36 & 3.24 \\
\hline Crystal size $(\mathrm{mm})$ & $0.30 \times 0.19 \times 0.12$ & $0.38 \times 0.23 \times 0.20$ \\
\hline \multicolumn{3}{|l|}{ Data collection } \\
\hline$T_{\min }, T_{\max }$ & $0.583,0.746$ & $0.541,0.746$ \\
\hline $\begin{array}{l}\text { No. of measured, } \\
\text { independent and } \\
\text { observed }[I>2 \sigma(I)] \\
\text { reflections }\end{array}$ & $36357,9379,8811$ & $13034,9360,8486$ \\
\hline$R_{\text {int }}$ & 0.029 & 0.019 \\
\hline$(\sin \theta / \lambda)_{\max }\left(\AA^{-1}\right)$ & 0.646 & 0.641 \\
\hline \multicolumn{3}{|l|}{ Refinement } \\
\hline $\begin{array}{l}R\left[F^{2}>2 \sigma\left(F^{2}\right)\right] \\
w R\left(F^{2}\right), S\end{array}$ & $0.019,0.044,1.06$ & $0.034,0.091,1.06$ \\
\hline No. of reflections & 9379 & 9360 \\
\hline No. of parameters & 556 & 571 \\
\hline No. of restraints & 15 & 0 \\
\hline$\Delta \rho_{\max }, \Delta \rho_{\min }\left(\mathrm{e} \AA^{-3}\right)$ & $0.93,-0.59$ & $2.14,-1.63$ \\
\hline
\end{tabular}



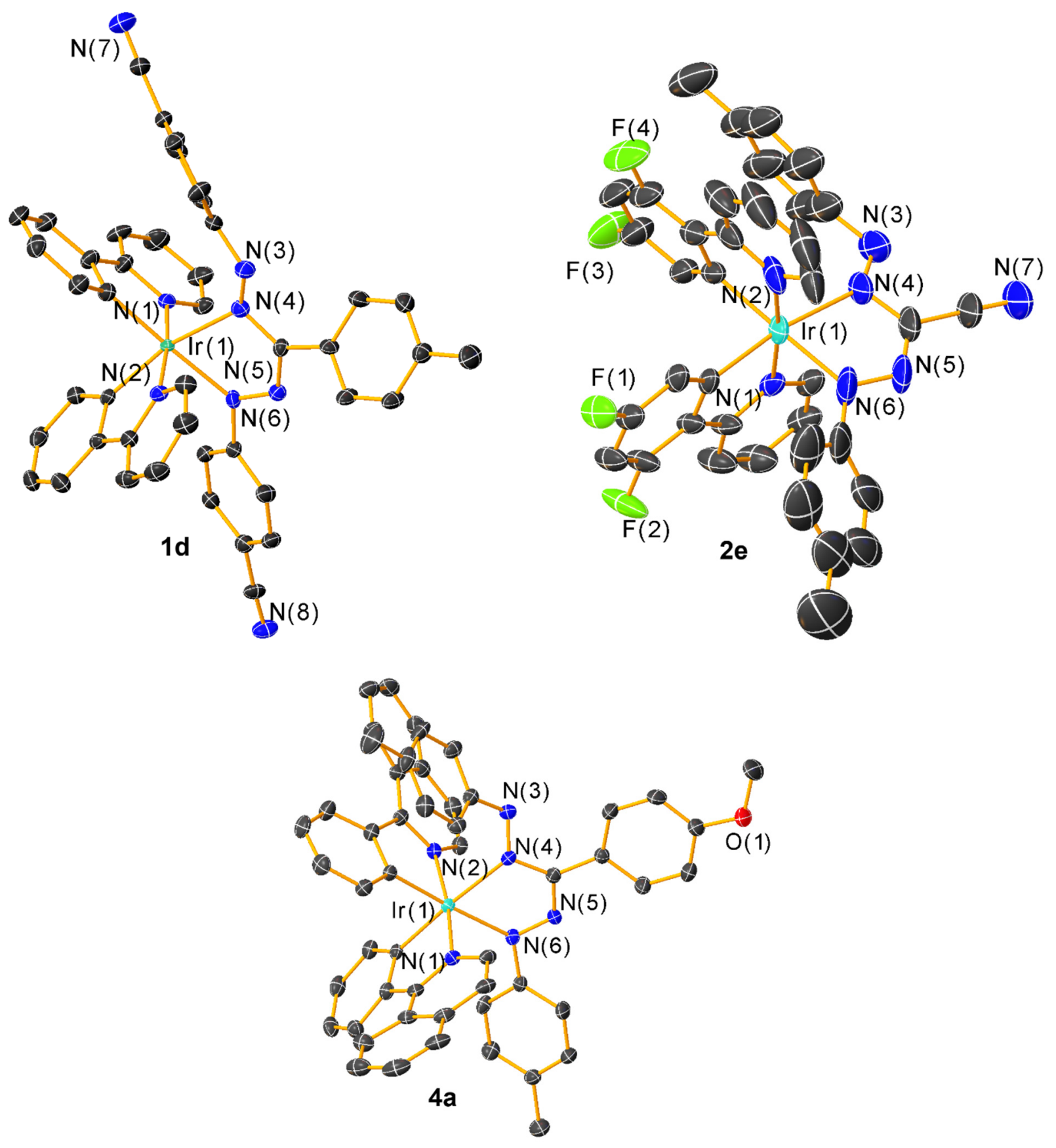

Figure S1. X-ray crystal structure of 1d, 2e, and 4a. Hydrogen atoms and solvate molecules are omitted for clarity. Ellipsoids are shown at the $50 \%$ probability level. 


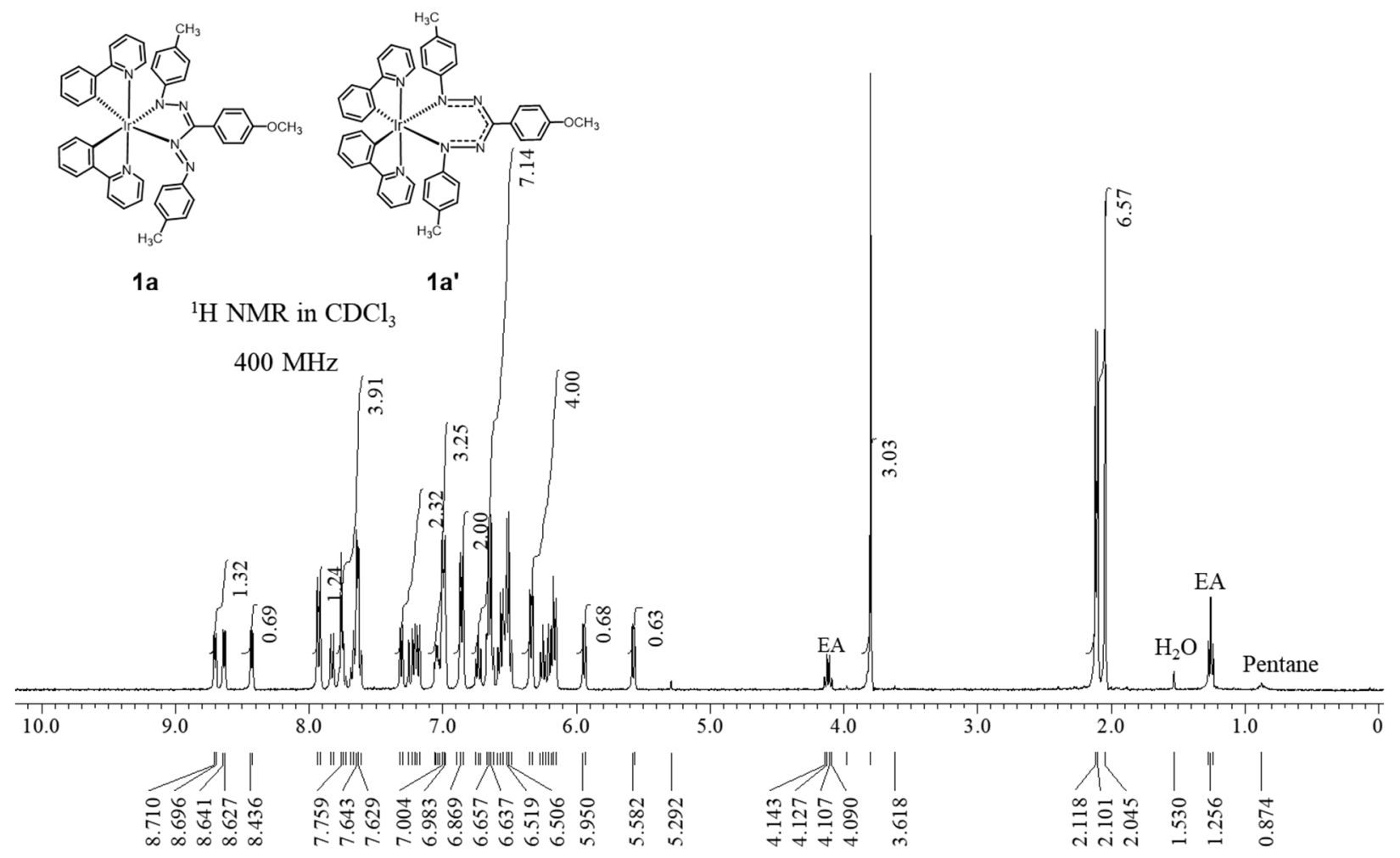

Figure S2. ${ }^{1} \mathrm{H}$ NMR spectrum of $\operatorname{Ir}(\text { ppy })_{2}$ (Fza) $\left(\mathbf{1 a}\right.$ and $\mathbf{1 a}$ '), recorded at $400 \mathrm{MHz}$ in $\mathrm{CDCl}_{3}$. Peak positions are shown below the horizontal axis. Signals for residual ethyl acetate (EA), pentane and $\mathrm{H}_{2} \mathrm{O}$ are marked.

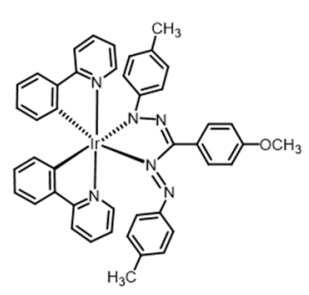

1a

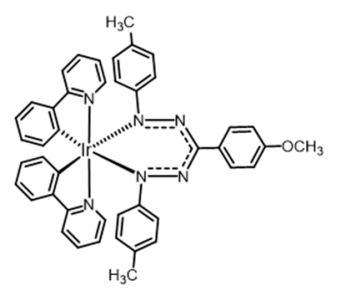

$1 a^{\prime}$

${ }^{13} \mathrm{C}\left\{{ }^{1} \mathrm{H}\right\} \mathrm{NMR}$ in $\mathrm{CDCl}_{3}$

$151 \mathrm{MHz}$

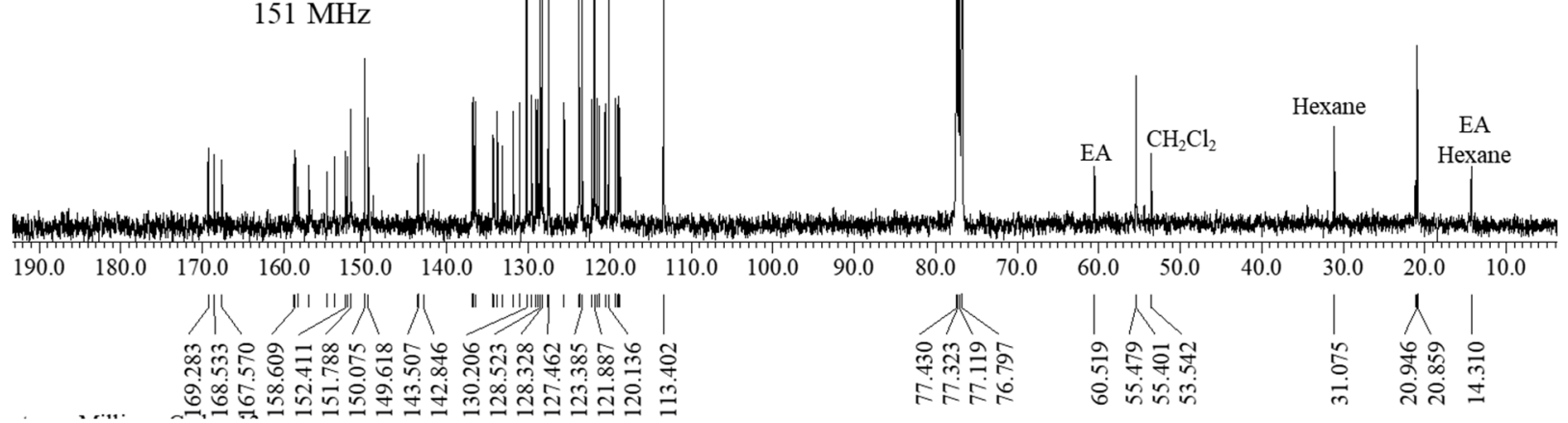

Figure S3. ${ }^{13} \mathrm{C}\left\{{ }^{1} \mathrm{H}\right\}$ NMR spectrum of $\operatorname{Ir}(\text { ppy })_{2}(\mathbf{F z a})(\mathbf{1 a}$ and $\mathbf{1 a})$, recorded at $151 \mathrm{MHz}$ in $\mathrm{CDCl}_{3}$. Peak positions are shown below the horizontal axis. Signals for residual ethyl acetate (EA), hexane and $\mathrm{CH}_{2} \mathrm{Cl}_{2}$ are marked. 


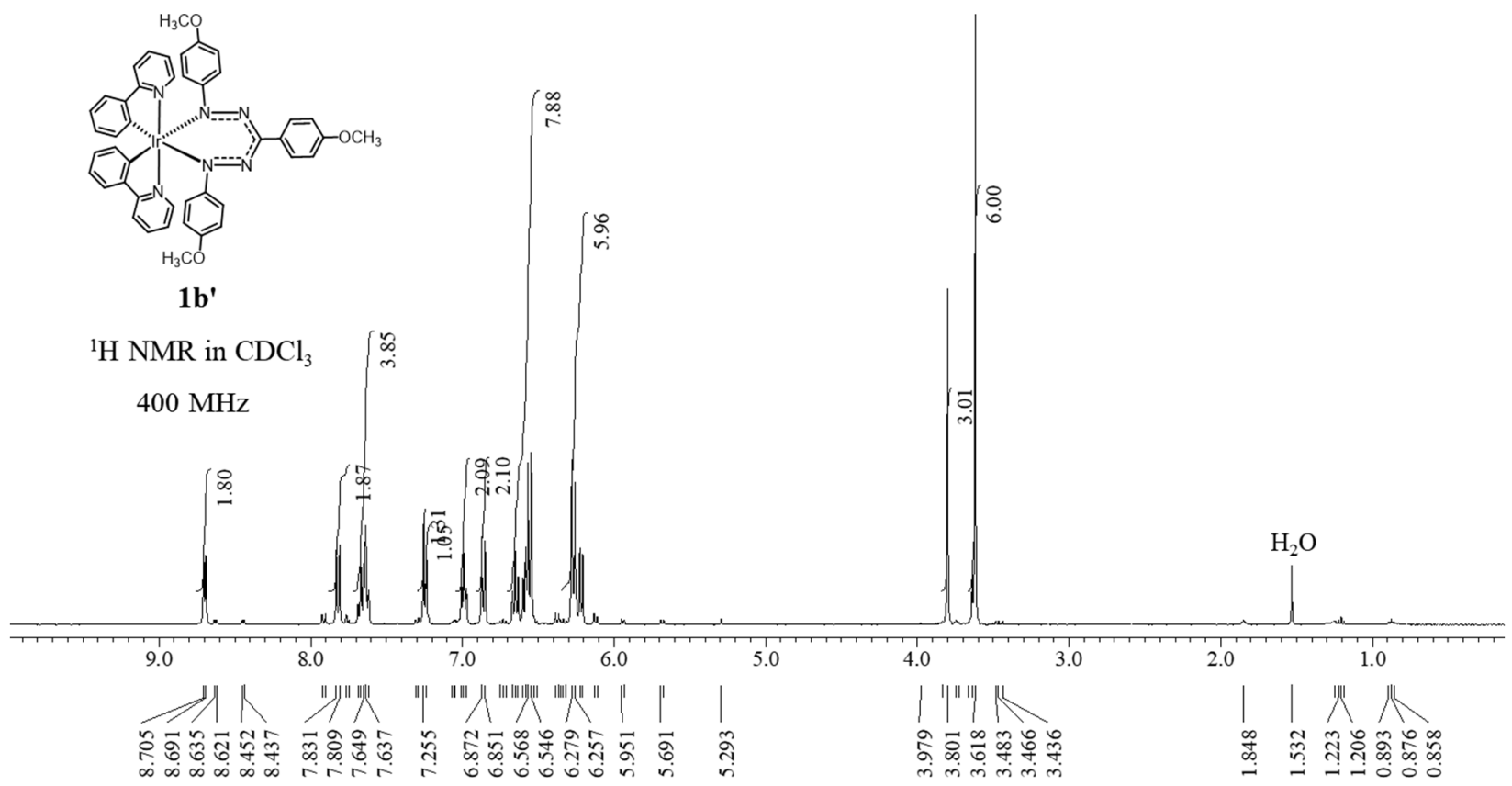

Figure S4. ${ }^{1} \mathrm{H}$ NMR spectrum of $\operatorname{Ir}(\mathrm{ppy})_{2}(\mathbf{F z b})\left(\mathbf{1 b}^{\prime}\right)$, recorded at $400 \mathrm{MHz}$ in $\mathrm{CDCl}_{3}$. Peak positions are shown below the horizontal axis. Signal for residual $\mathrm{H}_{2} \mathrm{O}$ is marked.

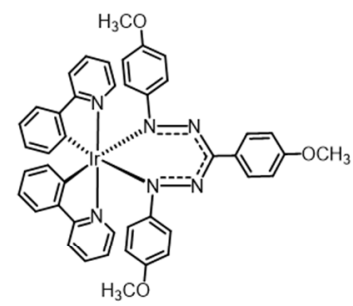

1b'

${ }^{13} \mathrm{C}\left\{{ }^{1} \mathrm{H}\right\}$ NMR in $\mathrm{CDCl}_{3}$

$151 \mathrm{MHz}$

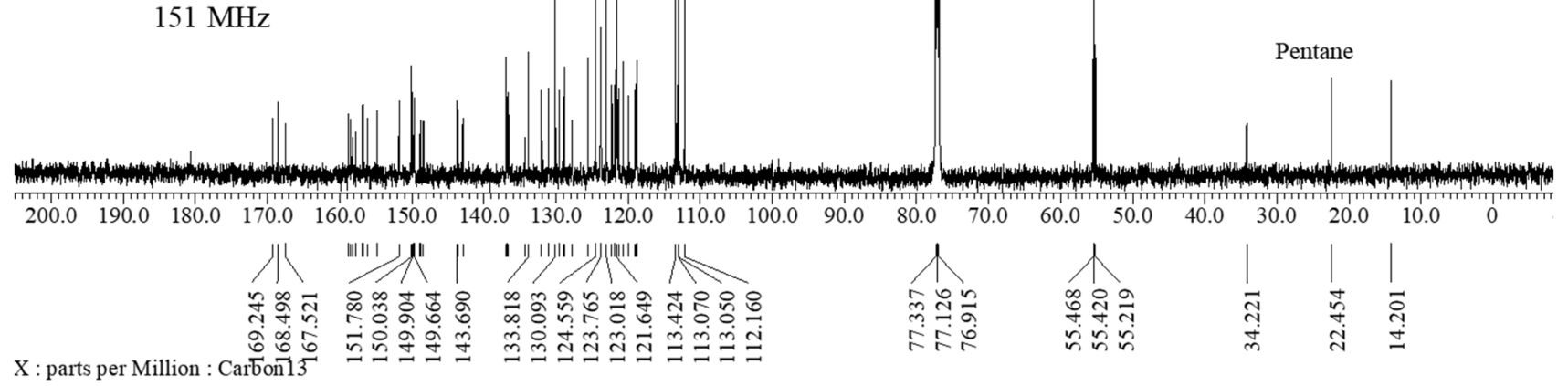

Figure S5. ${ }^{13} \mathrm{C}\left\{{ }^{1} \mathrm{H}\right\}$ NMR spectrum of $\operatorname{Ir}(\mathrm{ppy})_{2}(\mathbf{F z b})\left(\mathbf{1} \mathbf{b}^{\prime}\right)$, recorded at $151 \mathrm{MHz}$ in $\mathrm{CDCl}_{3}$. Peak positions are shown below the horizontal axis. Signals for residual pentane are marked. 


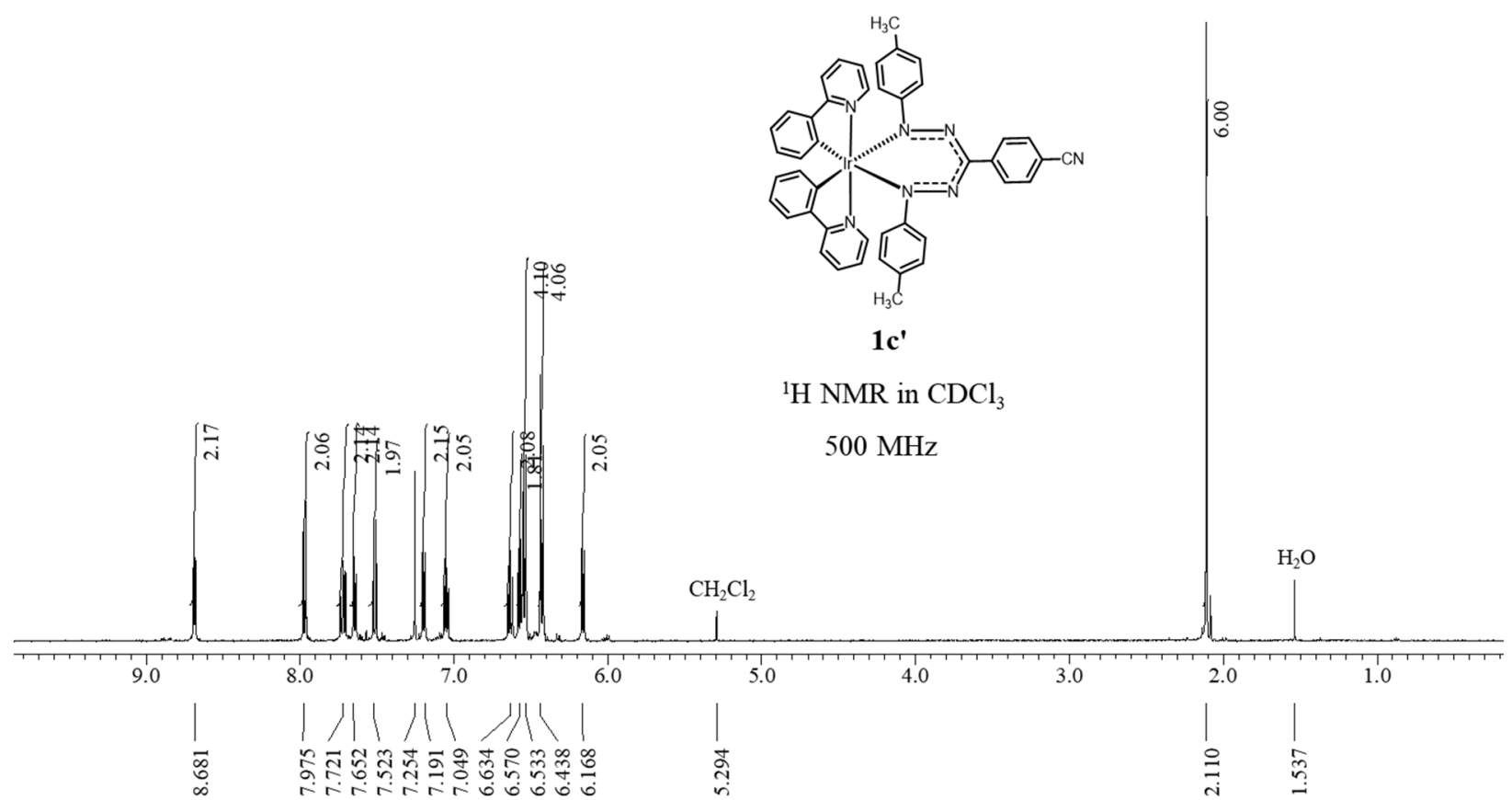

Figure S6. ${ }^{1} \mathrm{H}$ NMR spectrum of $\operatorname{Ir}(\text { ppy })_{2}(\mathbf{F z c})\left(\mathbf{1} \mathbf{c}^{\prime}\right)$, recorded at $500 \mathrm{MHz}$ in $\mathrm{CDCl}_{3}$. Peak positions are shown below the horizontal axis. Signals for residual $\mathrm{H}_{2} \mathrm{O}$ and $\mathrm{CH}_{2} \mathrm{Cl}_{2}$ are marked.

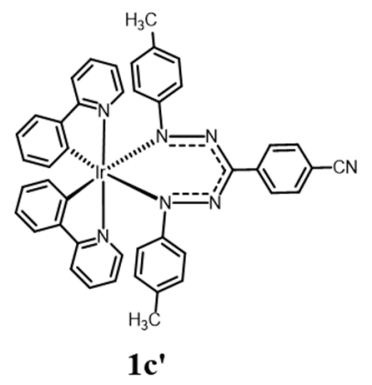

${ }^{13} \mathrm{C}\left\{{ }^{1} \mathrm{H}\right\} \mathrm{NMR}$ in $\mathrm{CDCl}_{3}$

$151 \mathrm{MHz}$

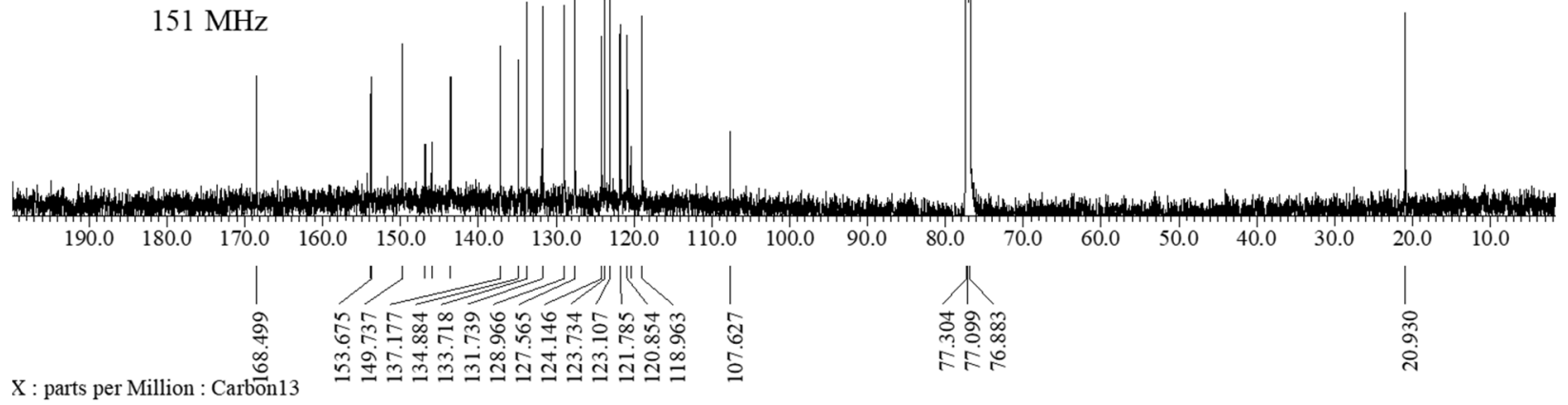

Figure S7. ${ }^{13} \mathrm{C}\left\{{ }^{1} \mathrm{H}\right\}$ NMR spectrum of $\operatorname{Ir}(\mathrm{ppy})_{2}(\mathbf{F z c})\left(\mathbf{1} \mathbf{c}^{\prime}\right)$, recorded at $151 \mathrm{MHz}$ in $\mathrm{CDCl}_{3}$. Peak positions are shown below the horizontal axis. 


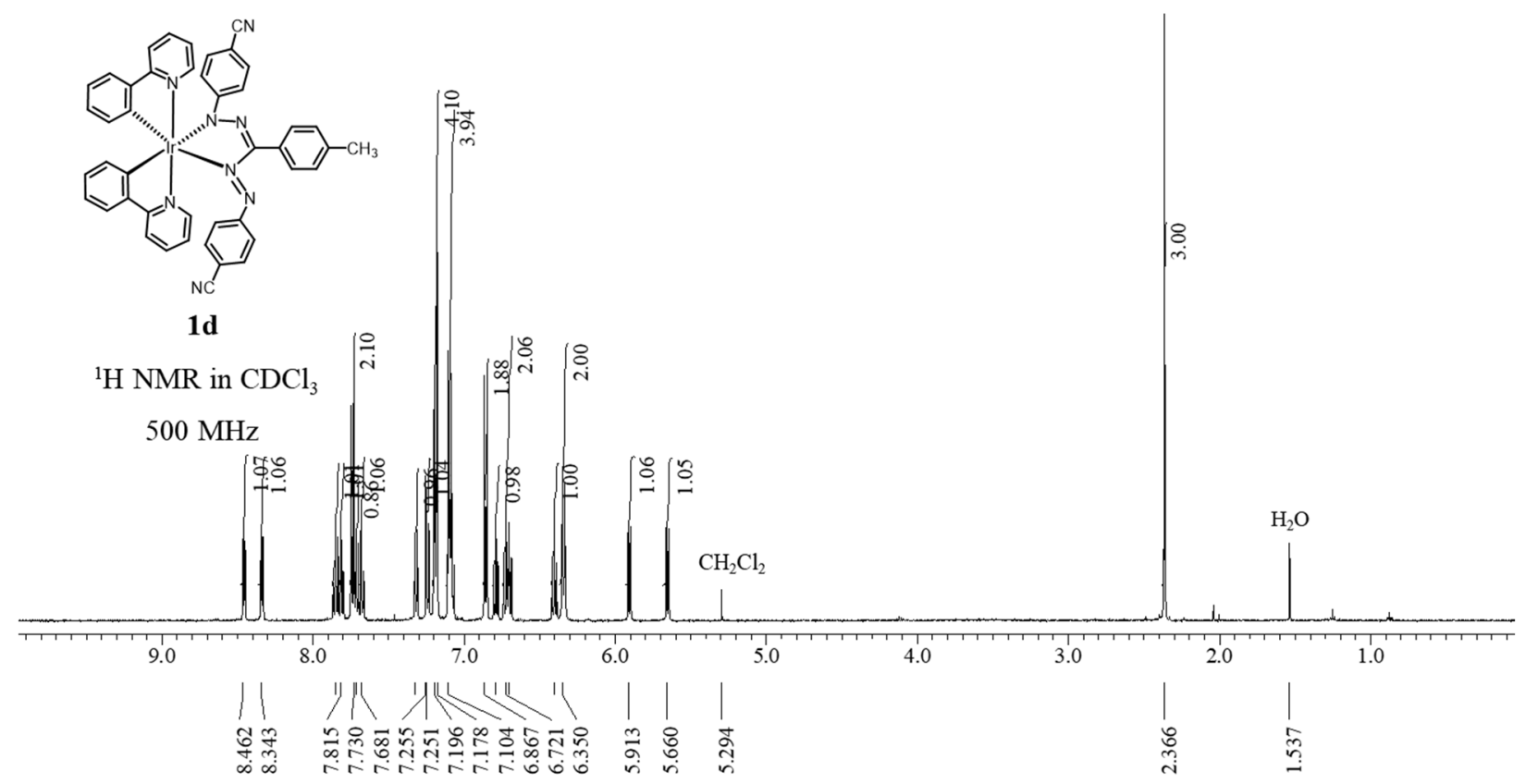

Figure S8. ${ }^{1} \mathrm{H}$ NMR spectrum of $\operatorname{Ir}(\text { ppy })_{2}(\mathbf{F z d})(\mathbf{1 d})$, recorded at $500 \mathrm{MHz}$ in $\mathrm{CDCl}_{3}$. Peak positions are shown below the horizontal axis. Signals for residual $\mathrm{H}_{2} \mathrm{O}$ and $\mathrm{CH}_{2} \mathrm{Cl}_{2}$ are marked.

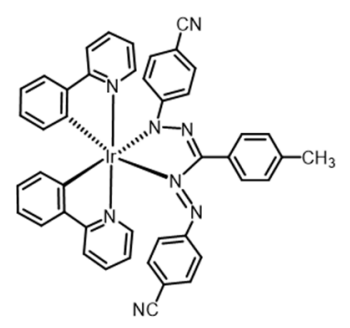

$1 d$

${ }^{13} \mathrm{C}\left\{{ }^{1} \mathrm{H}\right\} \mathrm{NMR}$ in $\mathrm{CDCl}_{3}$ $151 \mathrm{MHz}$

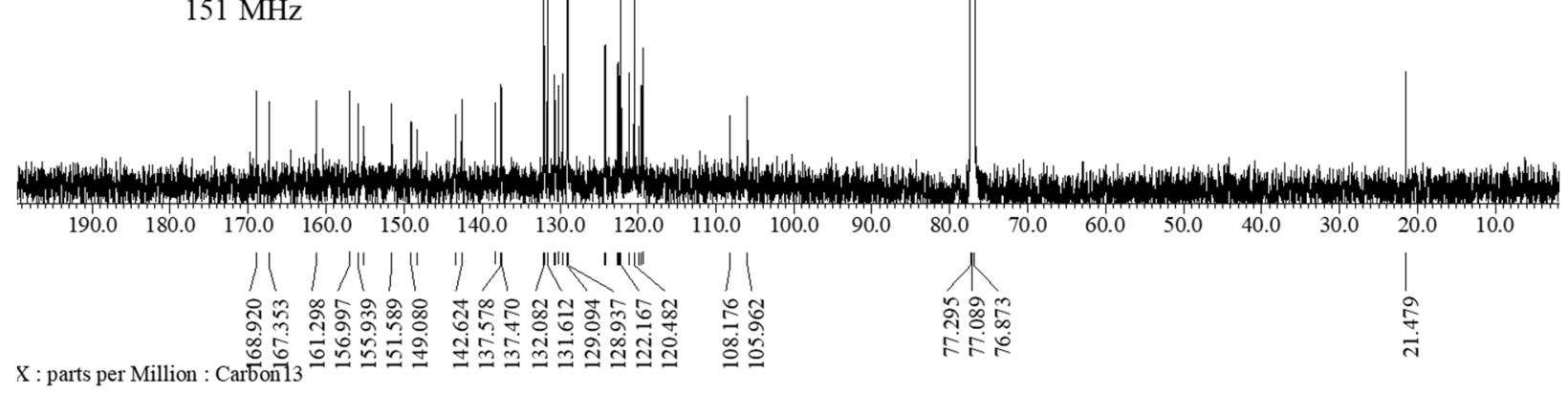

Figure S9. ${ }^{13} \mathrm{C}\left\{{ }^{1} \mathrm{H}\right\}$ NMR spectrum of $\operatorname{Ir}(\mathrm{ppy})_{2}(\mathbf{F z d})(\mathbf{1 d})$, recorded at $151 \mathrm{MHz}$ in $\mathrm{CDCl}_{3}$. Peak positions are shown below the horizontal axis. 


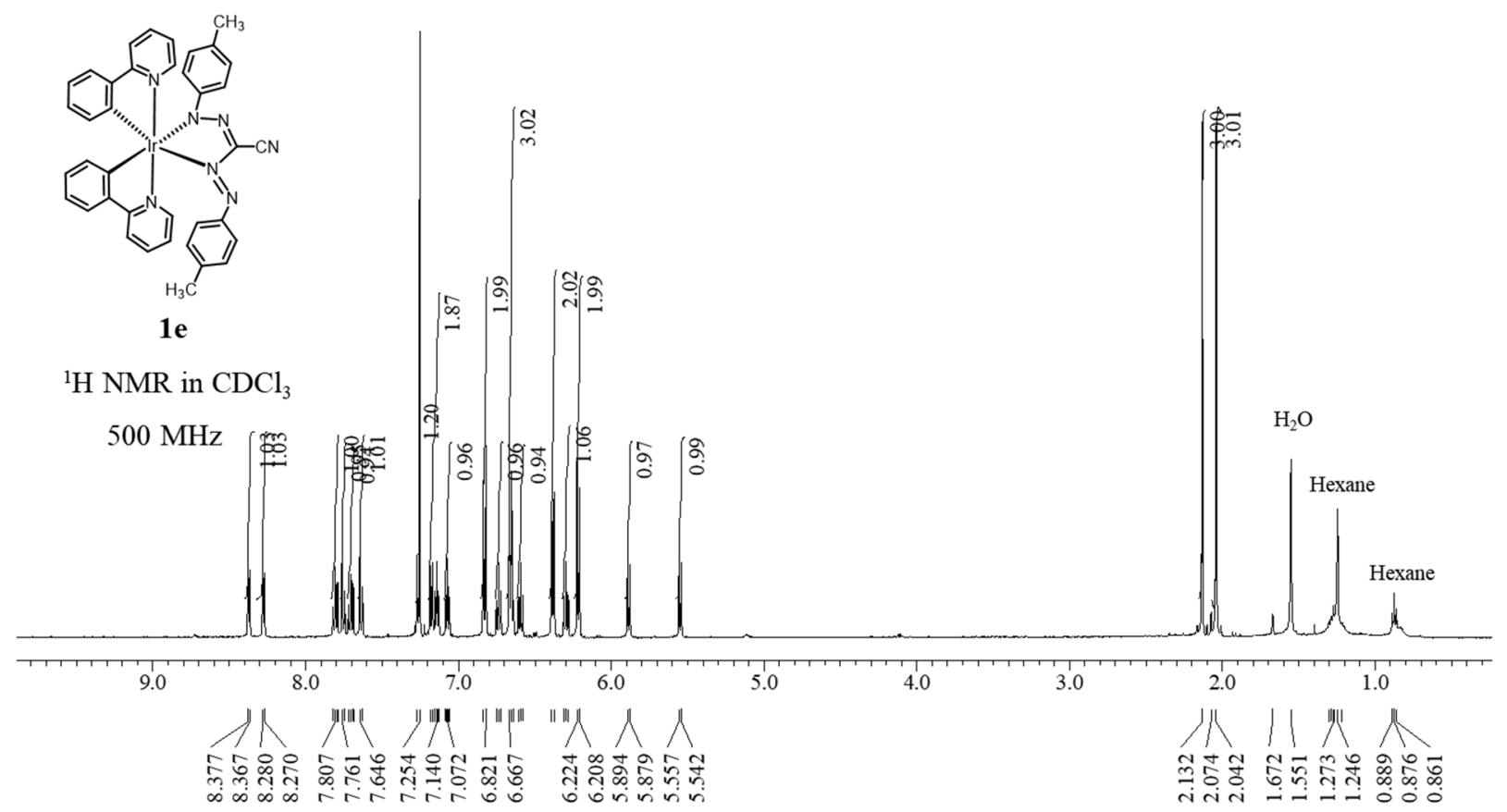

Figure S10. ${ }^{1} \mathrm{H}$ NMR spectrum of $\operatorname{Ir}(\text { ppy })_{2}$ (Fze) (1e), recorded at $500 \mathrm{MHz}$ in $\mathrm{CDCl}_{3}$. Peak positions are shown below the horizontal axis. Signals for residual $\mathrm{H}_{2} \mathrm{O}$ and hexane are marked.

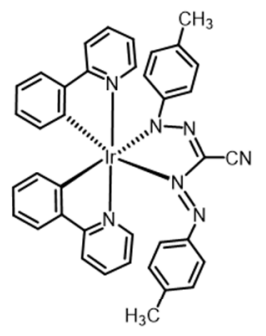

$1 \mathrm{e}$

${ }^{13} \mathrm{C}\left\{{ }^{1} \mathrm{H}\right\} \mathrm{NMR}$ in $\mathrm{CDCl}_{3}$ $151 \mathrm{MHz}$
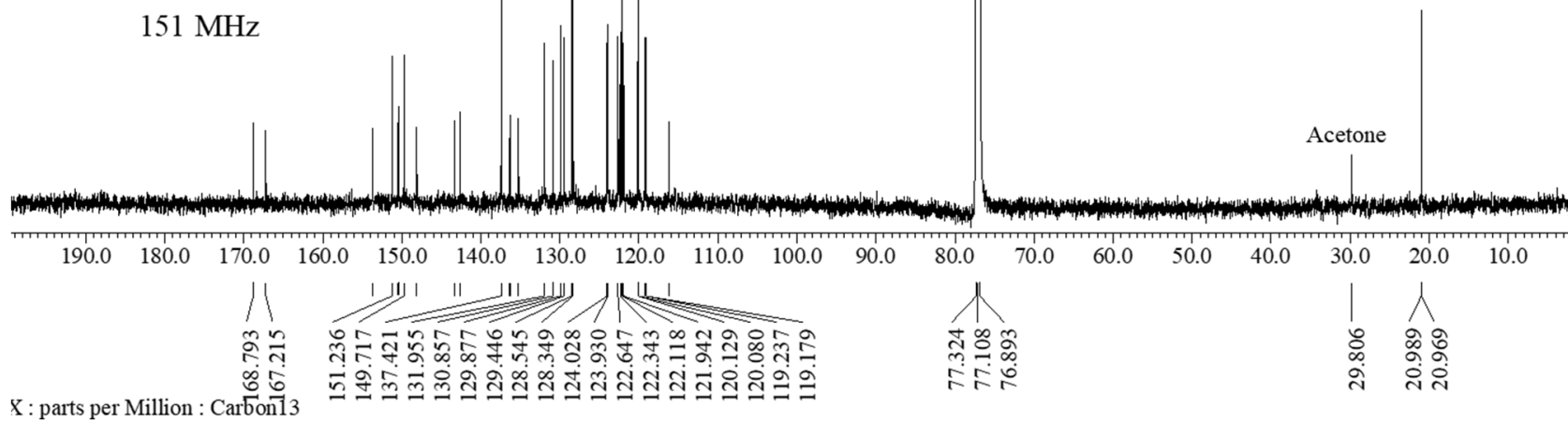

Figure S11. ${ }^{13} \mathrm{C}\left\{{ }^{1} \mathrm{H}\right\}$ NMR spectrum of $\operatorname{Ir}(\text { ppy })_{2}($ Fze $)(\mathbf{1 e})$, recorded at $151 \mathrm{MHz}$ in $\mathrm{CDCl}_{3}$. Peak positions are shown below the horizontal axis. Signal for residual acetone which was used to clean the NMR tube is marked. 


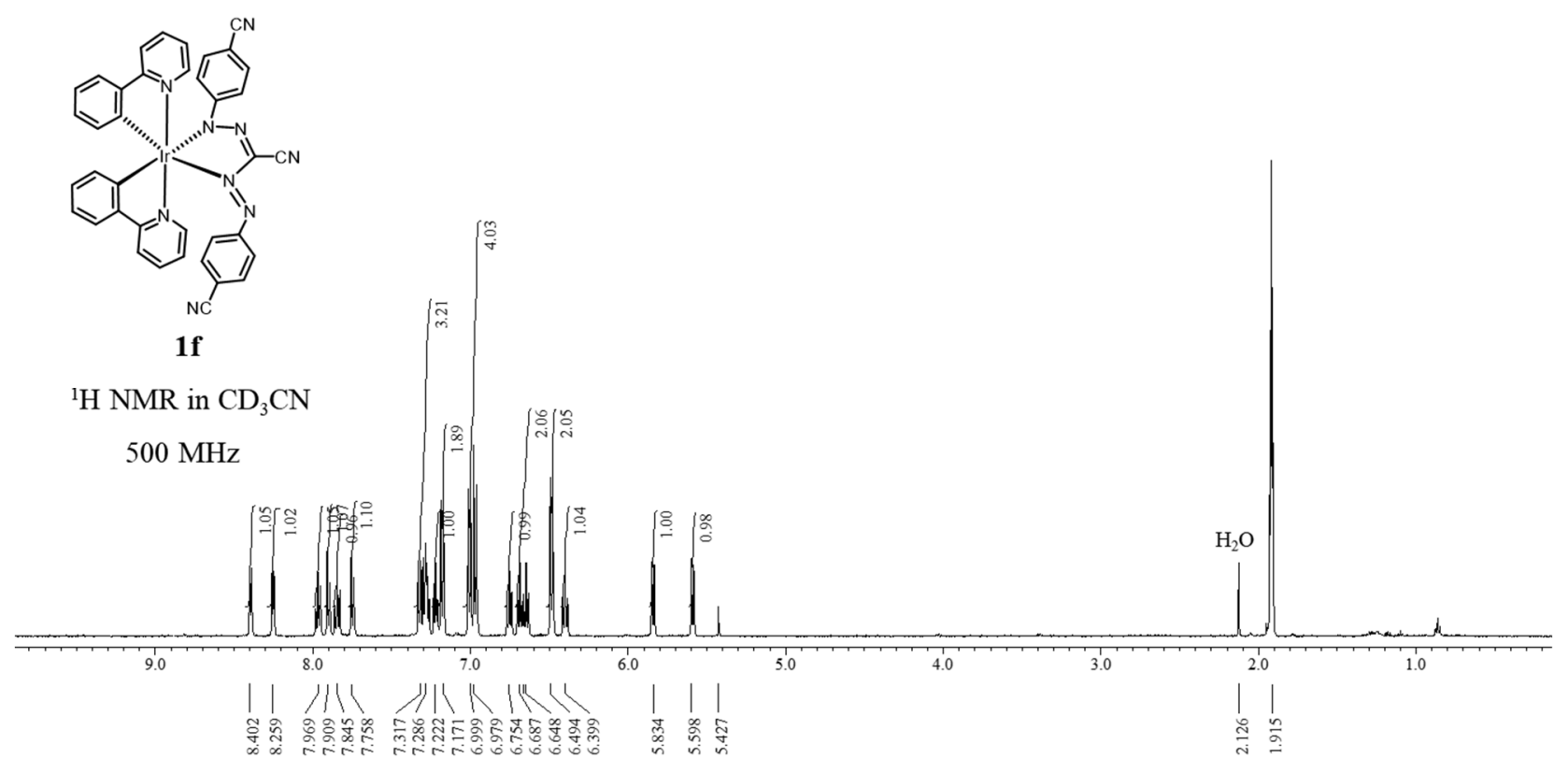

Figure S12. ${ }^{1} \mathrm{H}$ NMR spectrum of $\operatorname{Ir}(\text { ppy })_{2}$ (Fzf) (1f), recorded at $500 \mathrm{MHz}$ in $\mathrm{CD}_{3} \mathrm{CN}$. Peak positions are shown below the horizontal axis. Signal for residual $\mathrm{H}_{2} \mathrm{O}$ is marked.

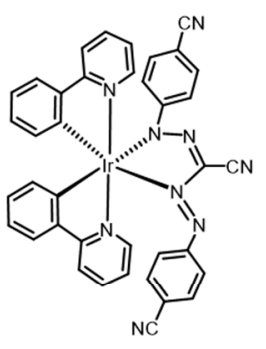

1f

${ }^{13} \mathrm{C}\left\{{ }^{1} \mathrm{H}\right\} \mathrm{NMR}$ in $\mathrm{CD}_{3} \mathrm{CN}$

$151 \mathrm{MHz}$

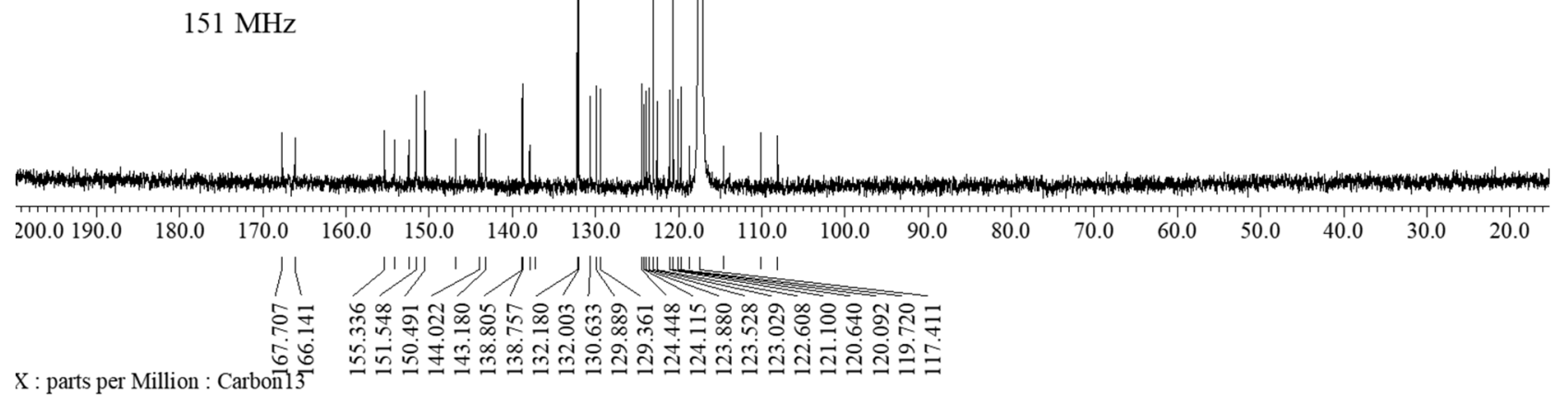

Figure S13. ${ }^{13} \mathrm{C}\left\{{ }^{1} \mathrm{H}\right\}$ NMR spectrum of $\operatorname{Ir}(\text { ppy })_{2}(\mathbf{F z f})(\mathbf{1 f})$, recorded at $151 \mathrm{MHz}$ in $\mathrm{CD}_{3} \mathrm{CN}$. Peak positions are shown below the horizontal axis. 


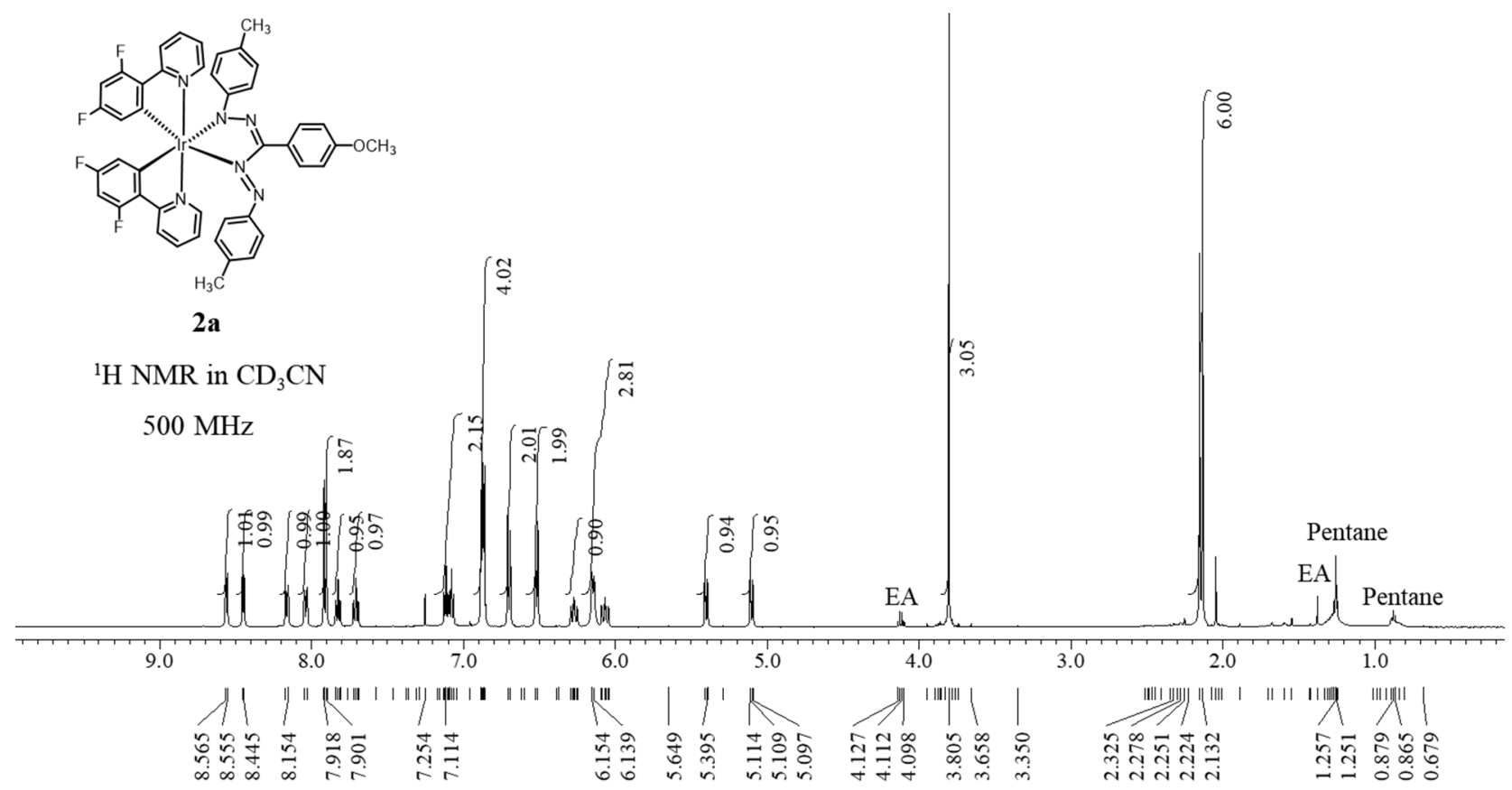

Figure S14. ${ }^{1} \mathrm{H}$ NMR spectrum of $\operatorname{Ir}\left(\mathrm{F}_{2} \mathrm{ppy}\right)_{2}$ (Fza) (2a), recorded at $500 \mathrm{MHz}$ in $\mathrm{CD}_{3} \mathrm{CN}$. Peak positions are shown below the horizontal axis. Signals for residual ethyl acetate (EA) and pentane are marked.

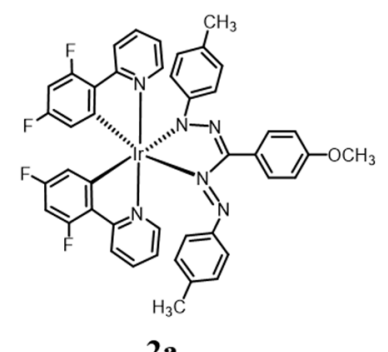

${ }^{13} \mathrm{C}\left\{{ }^{1} \mathrm{H}\right\} \mathrm{NMR}$ in $\mathrm{CD}_{3} \mathrm{CN}$

$126 \mathrm{MHz}$

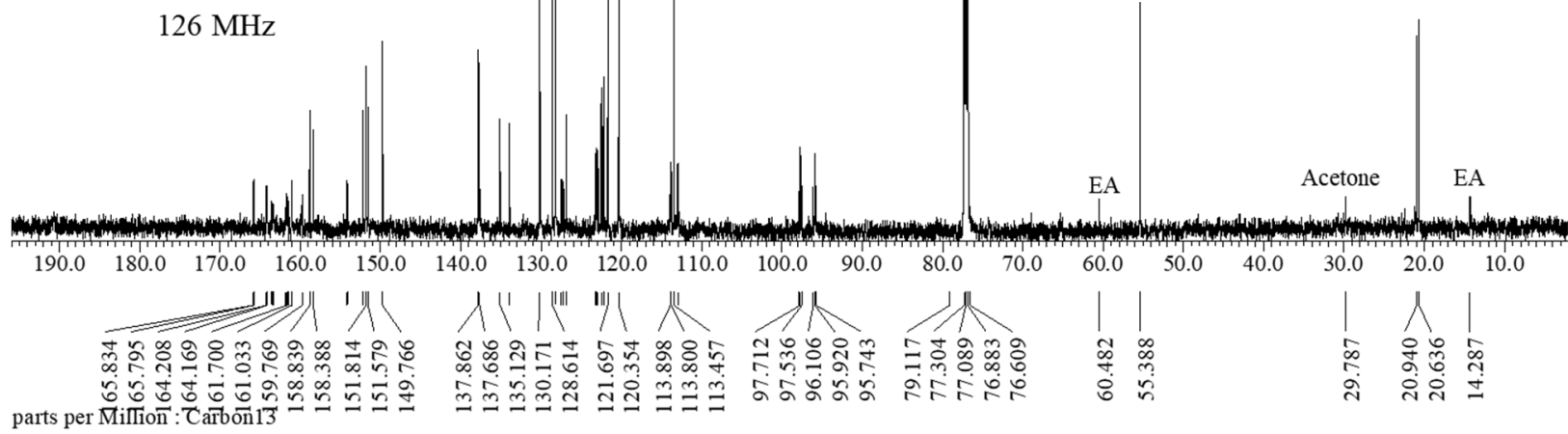

Figure S15. ${ }^{13} \mathrm{C}\left\{{ }^{1} \mathrm{H}\right\}$ NMR spectrum of $\operatorname{Ir}\left(\mathrm{F}_{2} \text { ppy) }\right)_{2}(\mathrm{Fza})$ (2a), recorded at $126 \mathrm{MHz}$ in $\mathrm{CD}_{3} \mathrm{CN}$. Peak positions are shown below the horizontal axis. Signals for residual ethyl acetate (EA), $\mathrm{CH}_{2} \mathrm{Cl}_{2}$, and acetone (used to clean NMR tube) are marked. 


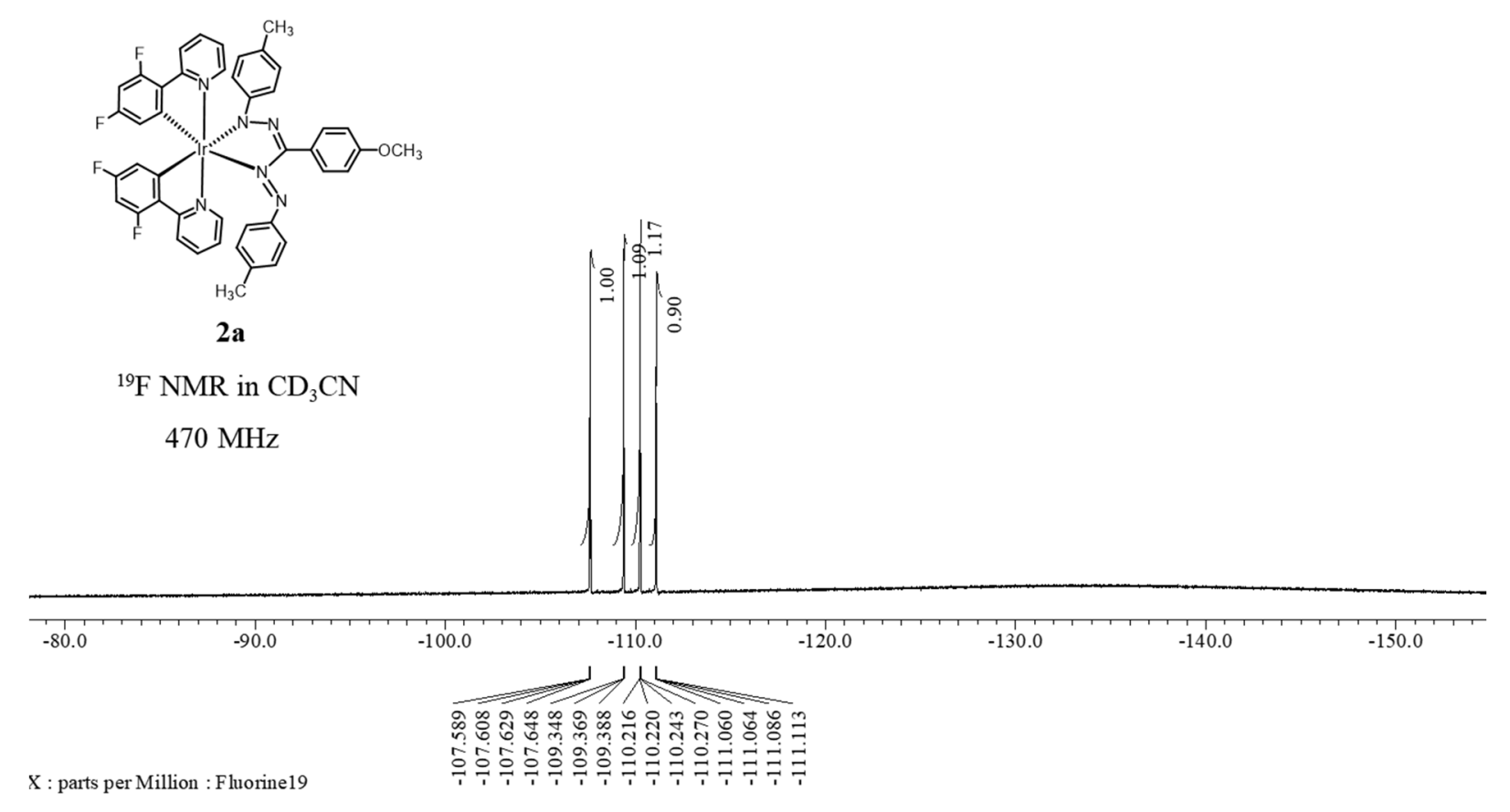

Figure S16. ${ }^{19} \mathrm{~F}$ NMR spectrum of $\operatorname{Ir}\left(\mathrm{F}_{2} \mathrm{ppy}\right)_{2}(\mathbf{F z a})(\mathbf{2 a})$, recorded at $470 \mathrm{MHz}$ in $\mathrm{CD}_{3} \mathrm{CN}$. Peak positions are shown below the horizontal axis.

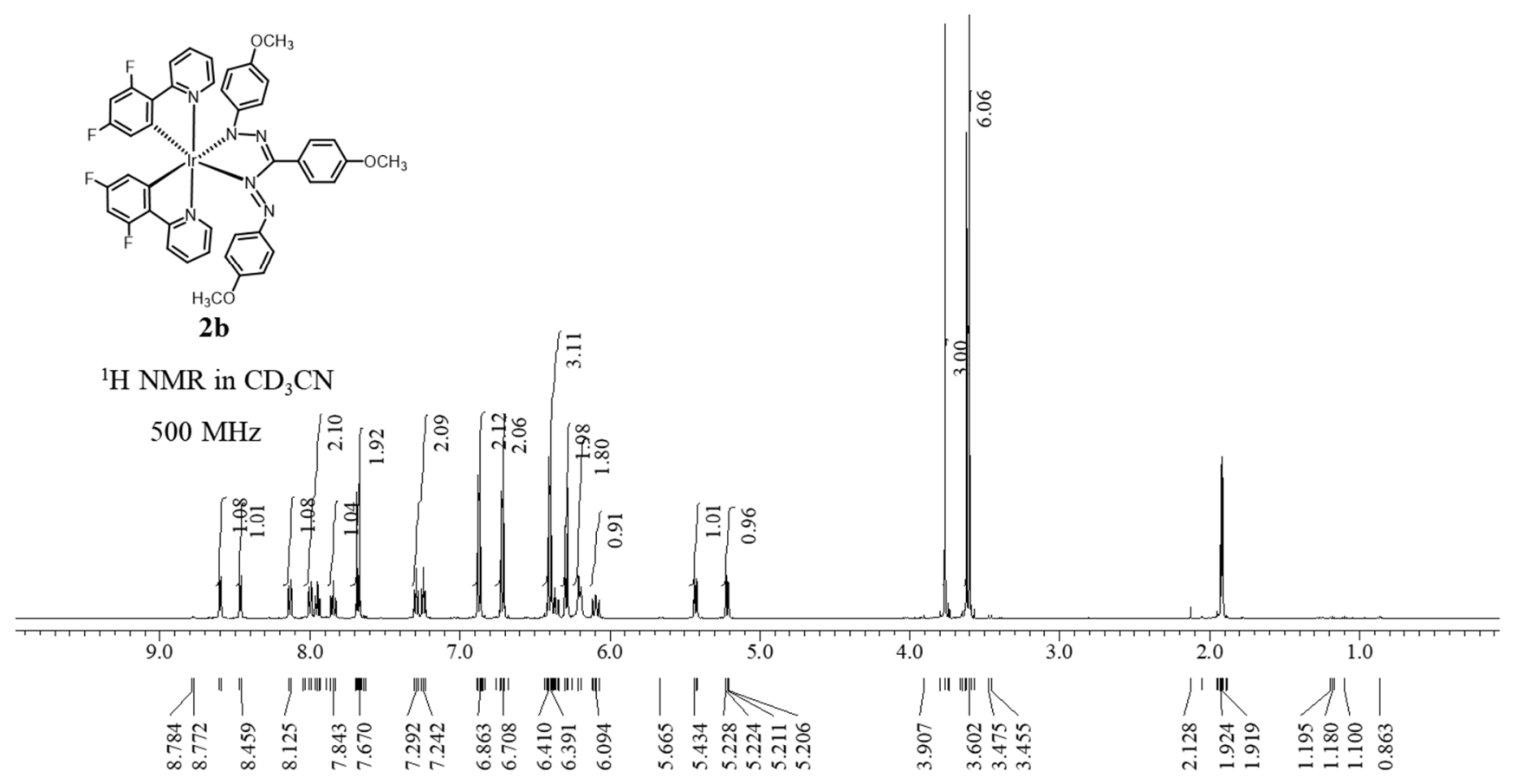

Figure S17. ${ }^{1} \mathrm{H}$ NMR spectrum of $\operatorname{Ir}\left(\mathrm{F}_{2} \mathrm{ppy}\right)_{2}(\mathbf{F z b})(\mathbf{2 b})$, recorded at $500 \mathrm{MHz}$ in $\mathrm{CD}_{3} \mathrm{CN}$. Peak positions are shown below the horizontal axis. 


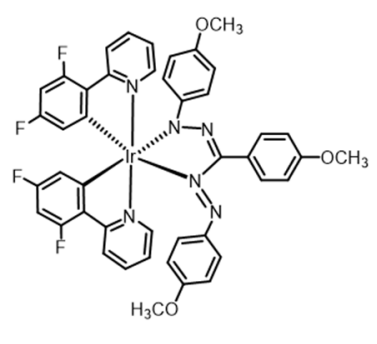

2b

${ }^{13} \mathrm{C}\left\{{ }^{1} \mathrm{H}\right\} \mathrm{NMR}$ in $\mathrm{CD}_{3} \mathrm{CN}$

$126 \mathrm{MHz}$

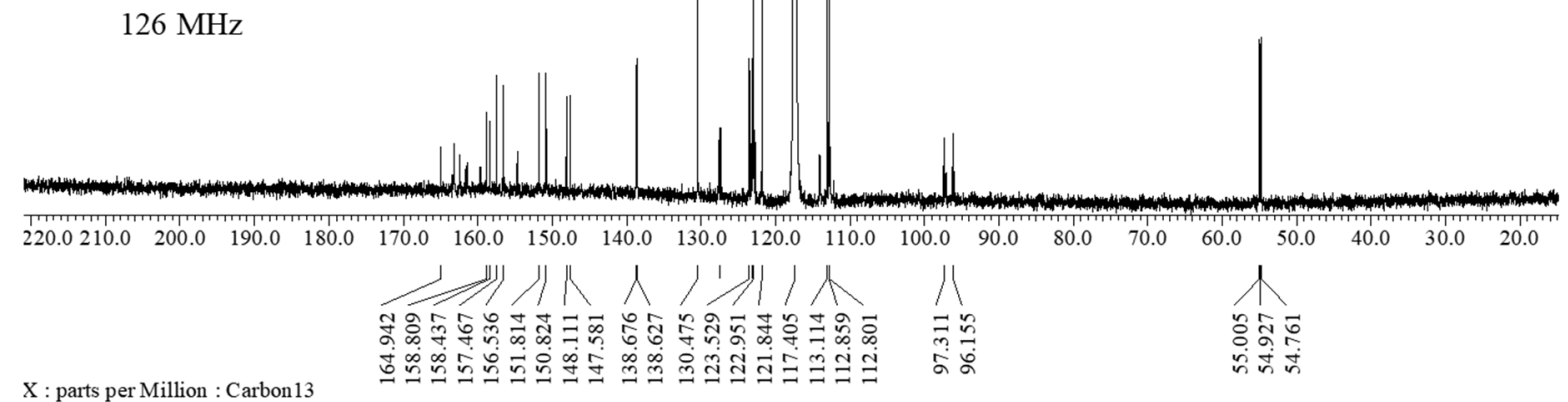

$\mathrm{X}$ : parts per Million : Carbon13

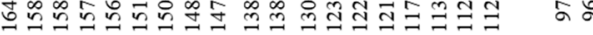

Figure S18. ${ }^{13} \mathrm{C}\left\{{ }^{1} \mathrm{H}\right\}$ NMR spectrum of $\operatorname{Ir}\left(\mathrm{F}_{2} \text { ppy }\right)_{2}(\mathbf{F z b})(\mathbf{2 b})$, recorded at $126 \mathrm{MHz}$ in $\mathrm{CD}_{3} \mathrm{CN}$. Peak positions are shown below the horizontal axis.

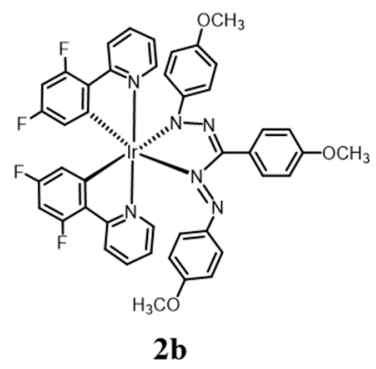

${ }^{19} \mathrm{~F} \mathrm{NMR}$ in $\mathrm{CD}_{3} \mathrm{CN}$

$470 \mathrm{MHz}$
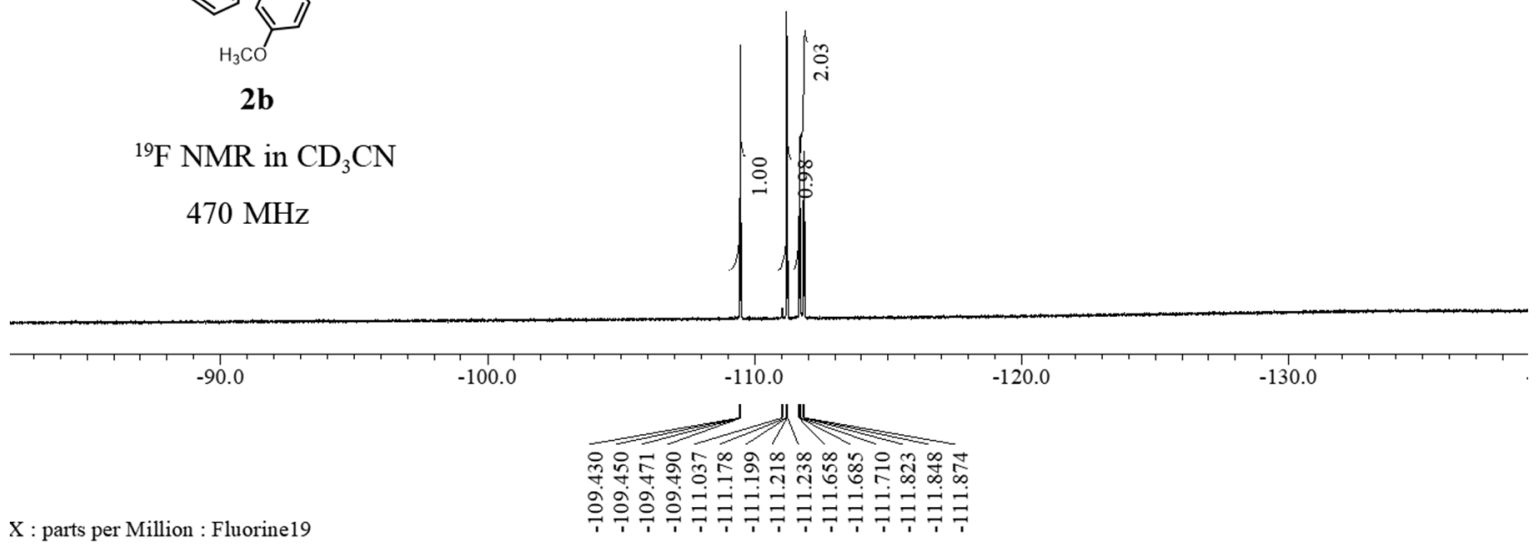

Figure S19. ${ }^{19} \mathrm{~F}$ NMR spectrum of $\operatorname{Ir}\left(\mathrm{F}_{2} \text { ppy }\right)_{2}(\mathbf{F z b})(\mathbf{2 b})$, recorded at $470 \mathrm{MHz}$ in $\mathrm{CD}_{3} \mathrm{CN}$. Peak positions are shown below the horizontal axis. 

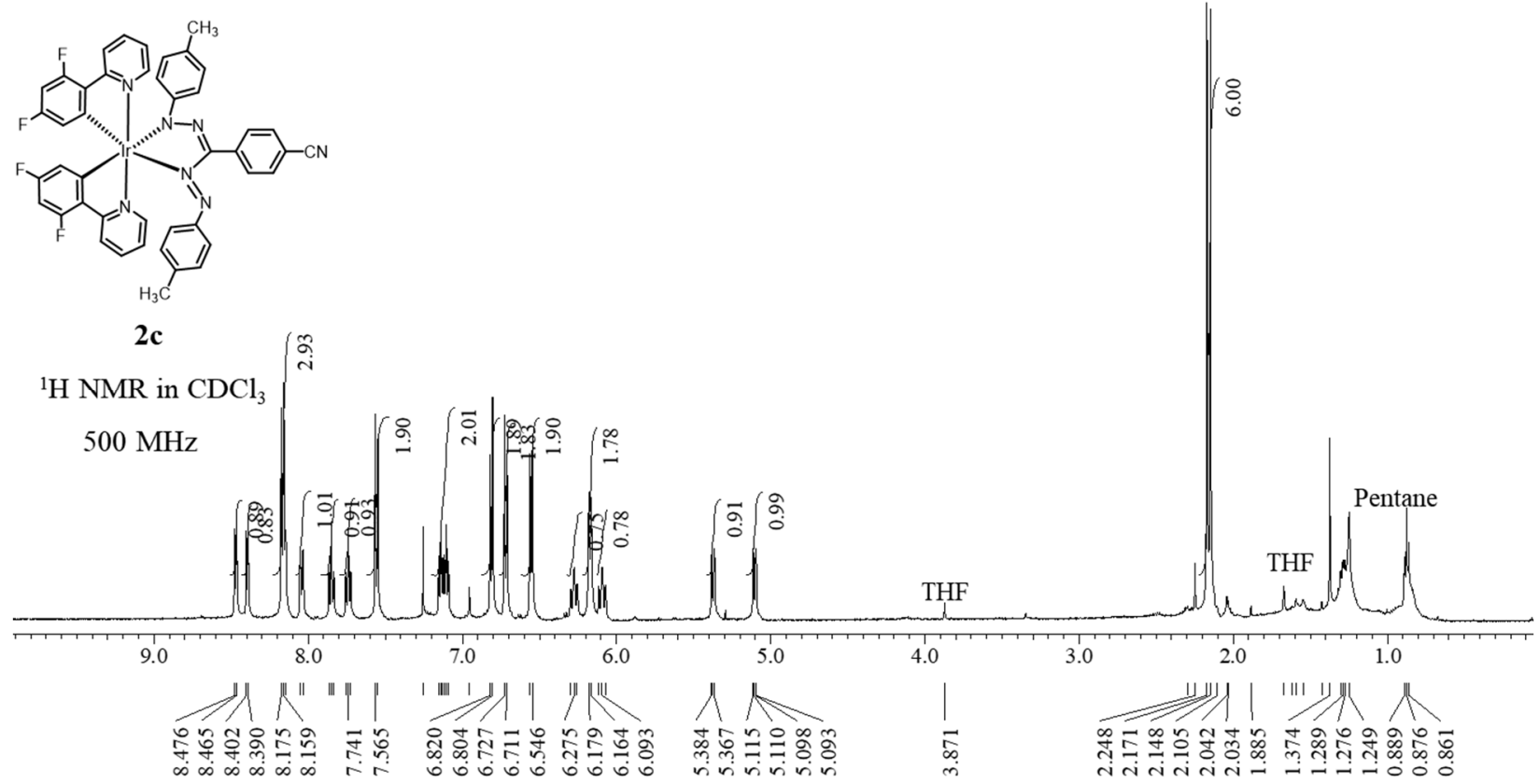

Figure S20. ${ }^{1} \mathrm{H}$ NMR spectrum of $\operatorname{Ir}\left(\mathrm{F}_{2} \mathrm{ppy}\right)_{2}(\mathbf{F z c})(\mathbf{2 c})$, recorded at $500 \mathrm{MHz}$ in $\mathrm{CDCl}_{3}$. Peak positions are shown below the horizontal axis. Signal for residual tetrahydrofuran (THF) and pentane is marked.

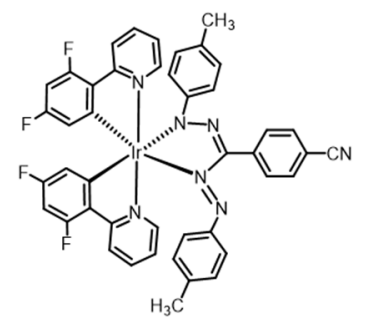

2c

${ }^{13} \mathrm{C}\left\{{ }^{1} \mathrm{H}\right\} \mathrm{NMR}$ in $\mathrm{CDCl}_{3}$ $151 \mathrm{MHz}$

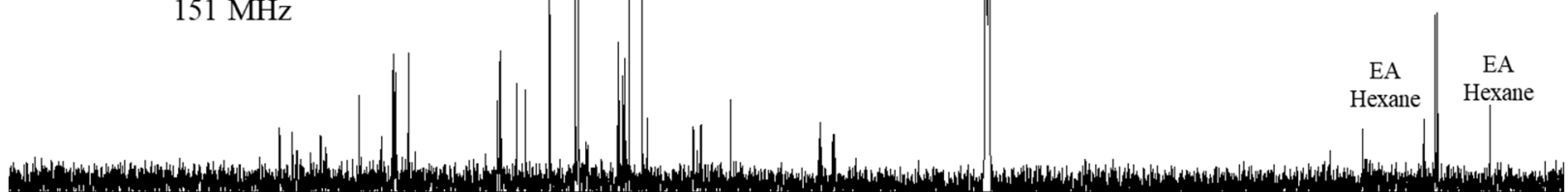

$\begin{array}{lllllllllllllllllll}190.0 & 180.0 & 170.0 & 160.0 & 150.0 & 140.0 & 130.0 & 120.0 & 110.0 & 100.0 & 90.0 & 80.0 & 70.0 & 60.0 & 50.0 & 40.0 & 30.0 & 20.0 & 10.0\end{array}$

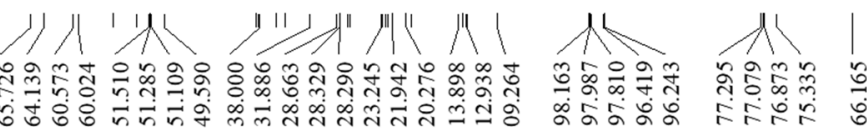
$\mathrm{X}$ : parts per Million : Car

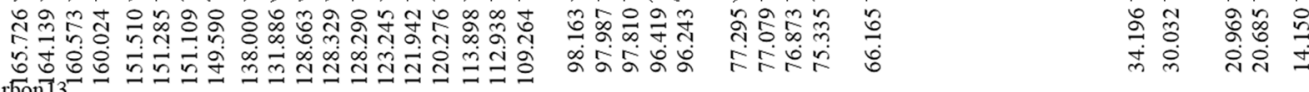

Figure S21. ${ }^{13} \mathrm{C}\left\{{ }^{1} \mathrm{H}\right\}$ NMR spectrum of $\operatorname{Ir}\left(\mathrm{F}_{2} \text { ppy }\right)_{2}(\mathbf{F z c})(\mathbf{2 c})$, recorded at $151 \mathrm{MHz}$ in $\mathrm{CDCl}_{3}$. Peak positions are shown below the horizontal axis. Signals for residual ethyl acetate (EA) and hexane are marked. 


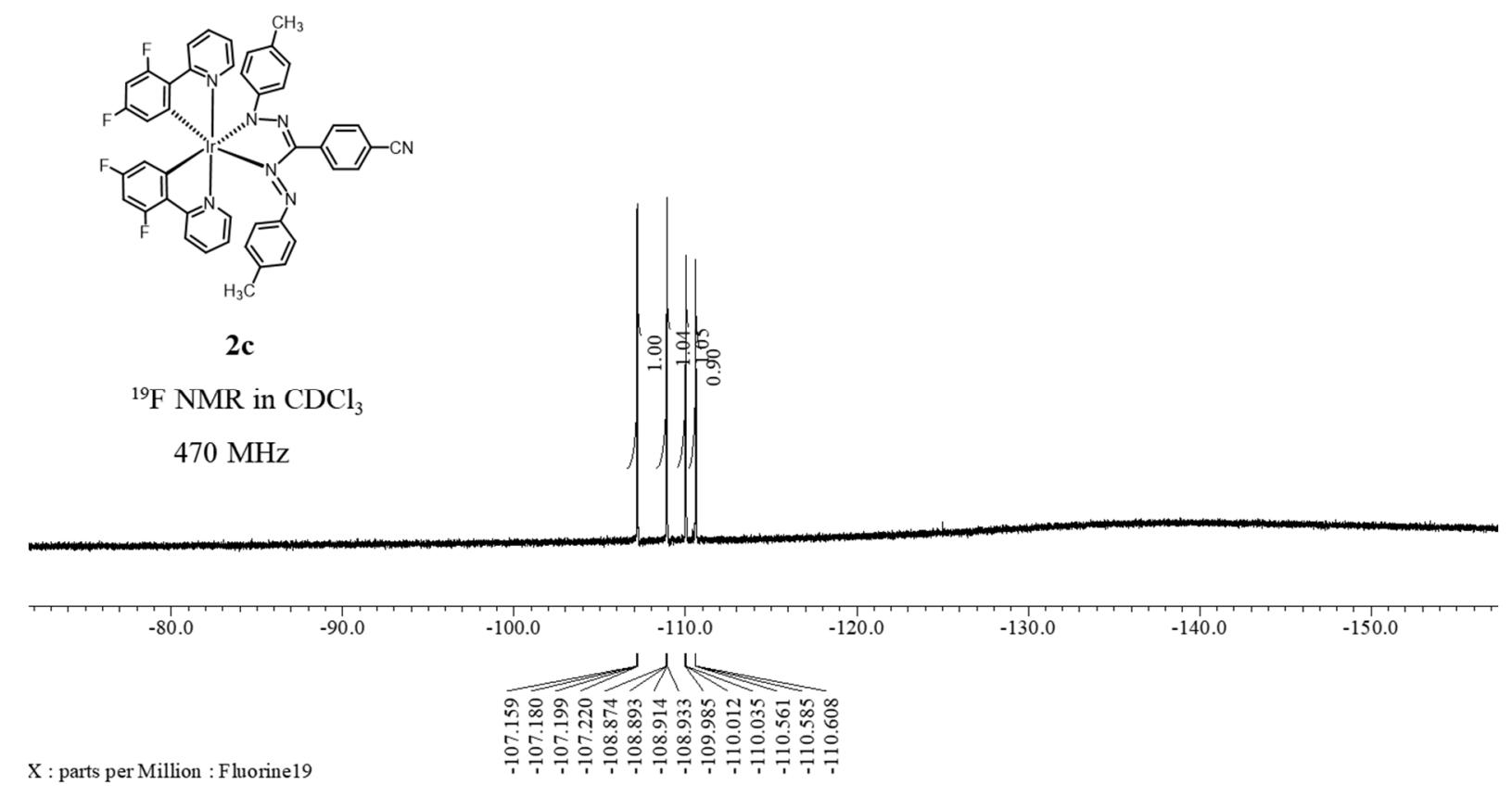

Figure S22. ${ }^{19} \mathrm{~F}$ NMR spectrum of $\operatorname{Ir}\left(\mathrm{F}_{2} \text { ppy }\right)_{2}(\mathbf{F z c})(\mathbf{2 c})$, recorded at $470 \mathrm{MHz}$ in $\mathrm{CDCl}_{3}$. Peak positions are shown below the horizontal axis.

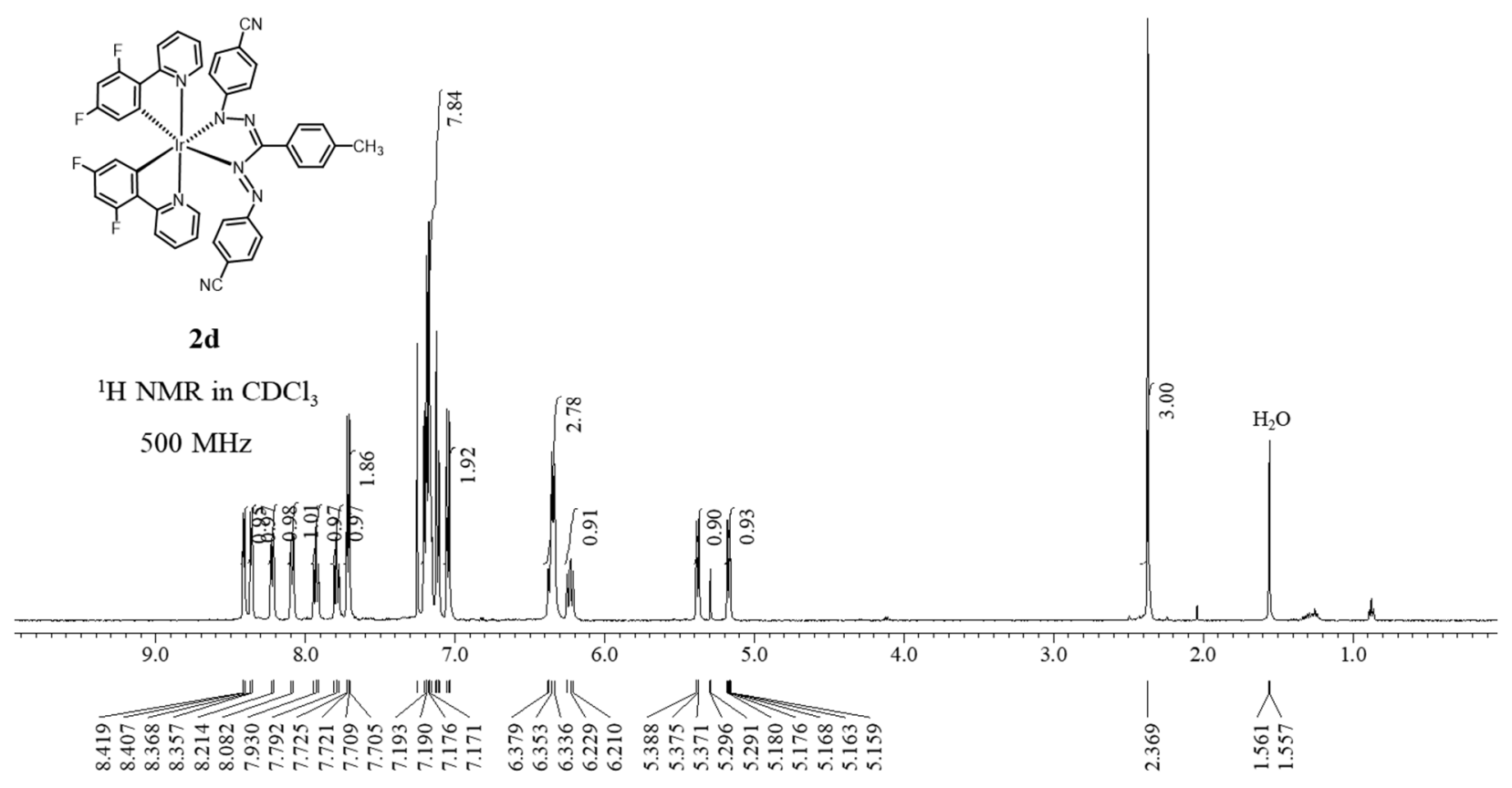

Figure S23. ${ }^{1} \mathrm{H}$ NMR spectrum of $\operatorname{Ir}\left(\mathrm{F}_{2} \mathrm{ppy}\right)_{2}(\mathbf{F z d})(\mathbf{2 d})$, recorded at $500 \mathrm{MHz}$ in $\mathrm{CDCl}_{3}$. Peak positions are shown below the horizontal axis. Signal for residual $\mathrm{H}_{2} \mathrm{O}$ is marked. 


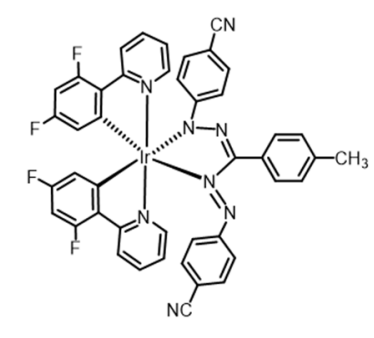

2d

${ }^{13} \mathrm{C}\left\{{ }^{1} \mathrm{H}\right\} \mathrm{NMR}$ in $\mathrm{CDCl}_{3}$

$151 \mathrm{MHz}$

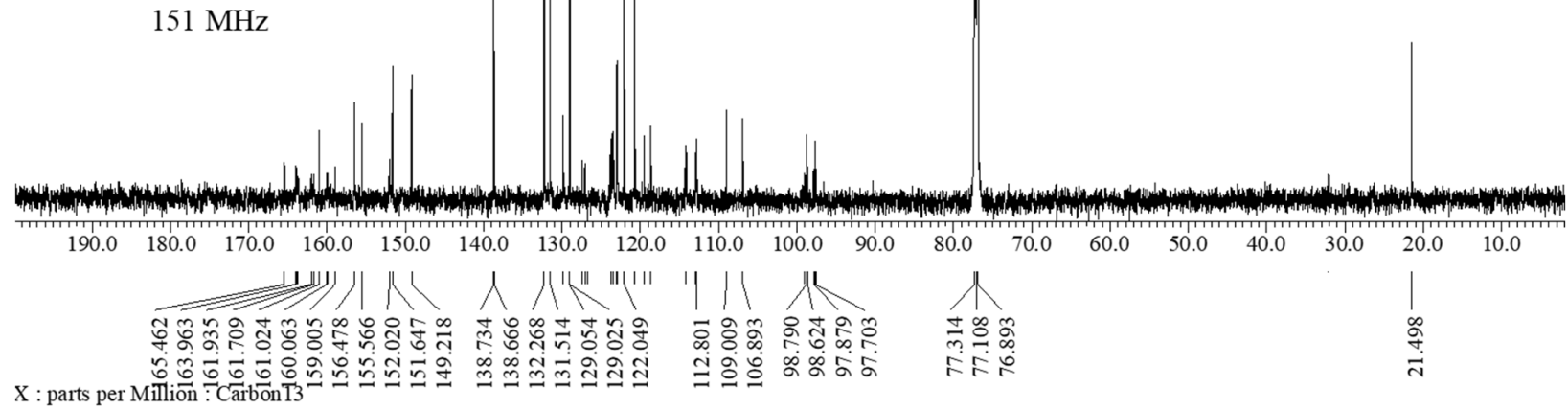

Figure S24. ${ }^{13} \mathrm{C}\left\{{ }^{1} \mathrm{H}\right\}$ NMR spectrum of $\operatorname{Ir}\left(\mathrm{F}_{2} \text { ppy }\right)_{2}\left(\right.$ Fzd) (2d), recorded at $151 \mathrm{MHz}$ in $\mathrm{CDCl}_{3}$. Peak positions are shown below the horizontal axis.

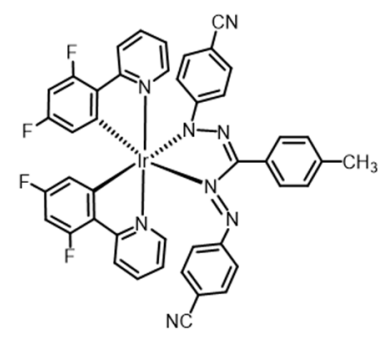

2d

${ }^{19} \mathrm{~F} \mathrm{NMR}$ in $\mathrm{CDCl}_{3}$

$470 \mathrm{MHz}$
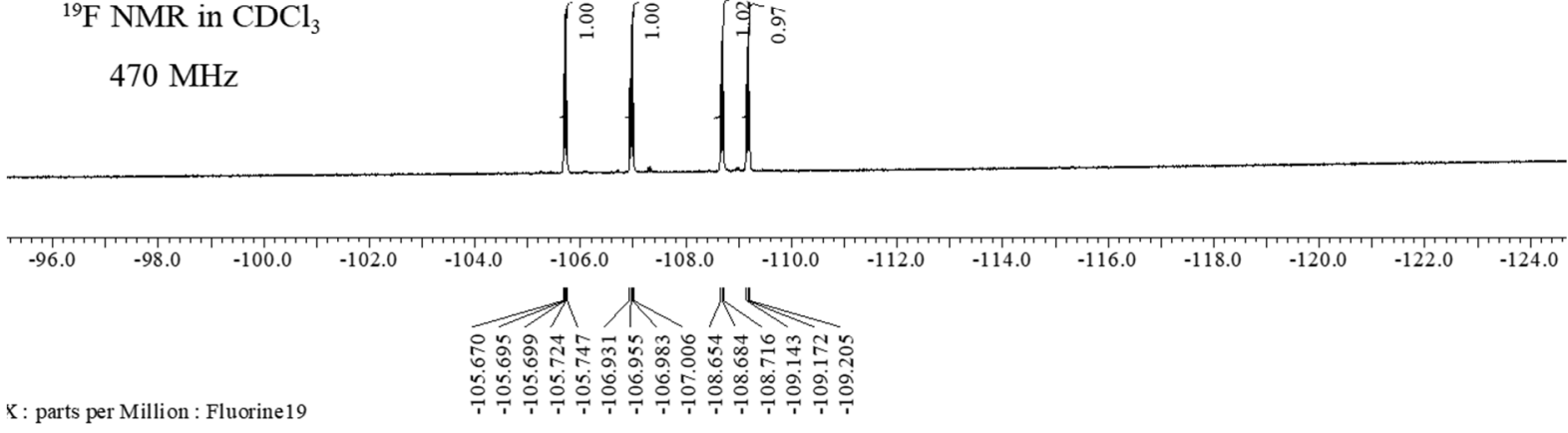

Figure S25. ${ }^{19} \mathrm{~F}$ NMR spectrum of $\operatorname{Ir}\left(\mathrm{F}_{2} \mathrm{ppy}\right)_{2}($ Fzd $)\left(\right.$ (2d), recorded at $470 \mathrm{MHz}$ in $\mathrm{CDCl}_{3}$. Peak positions are shown below the horizontal axis. 


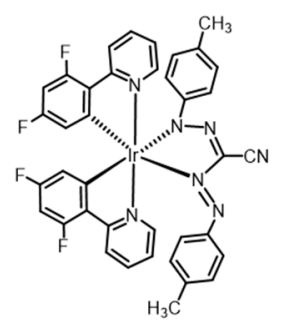

$2 \mathrm{e}$

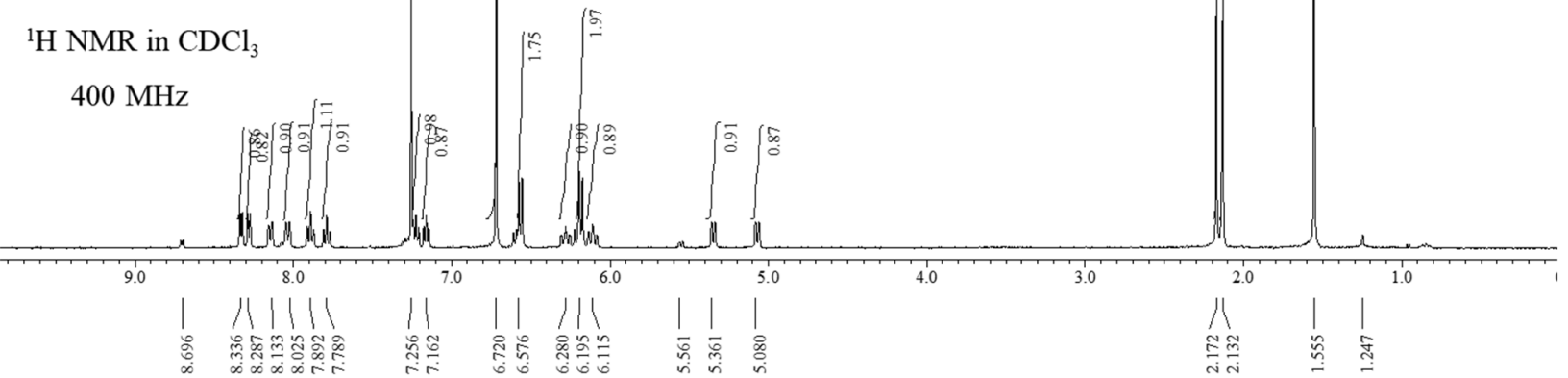

Figure S26. ${ }^{1} \mathrm{H}$ NMR spectrum of $\operatorname{Ir}\left(\mathrm{F}_{2} \mathrm{ppy}\right)_{2}(\mathbf{F z e})(\mathbf{2 e})$, recorded at $400 \mathrm{MHz}$ in $\mathrm{CDCl}_{3}$. Peak positions are shown below the horizontal axis. Signal for residual $\mathrm{H}_{2} \mathrm{O}$ is marked.

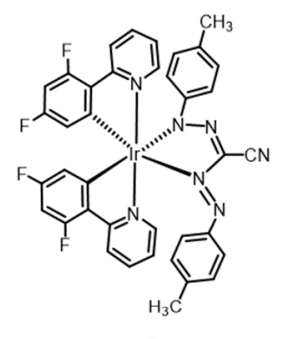

$2 \mathrm{e}$

${ }^{13} \mathrm{C}\left\{{ }^{1} \mathrm{H}\right\} \mathrm{NMR}$ in $\mathrm{CDCl}_{3}$

$151 \mathrm{MHz}$

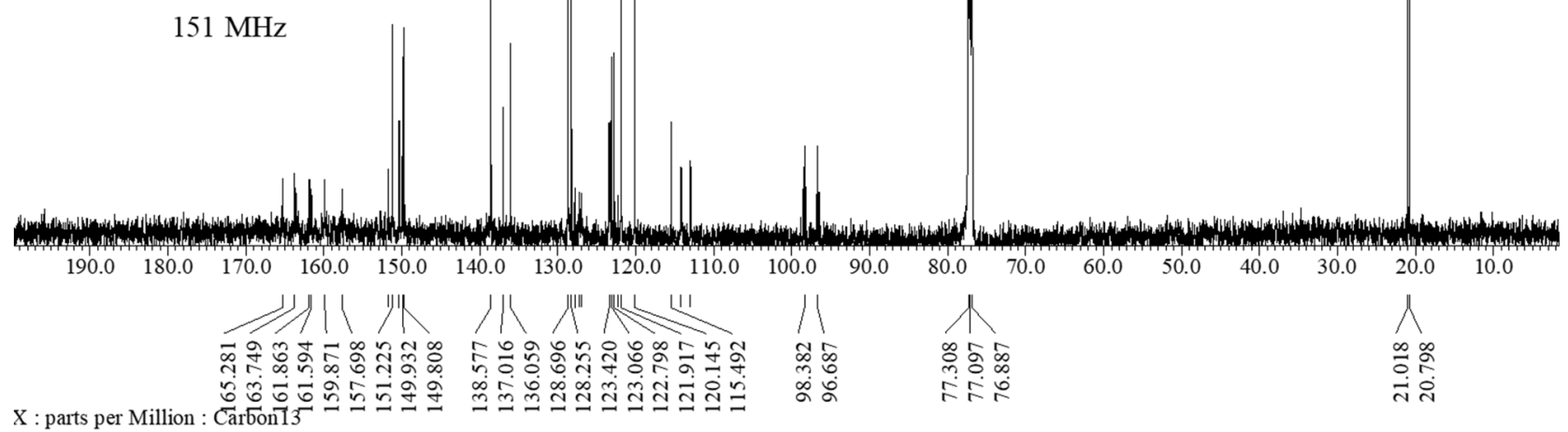

Figure S27. ${ }^{13} \mathrm{C}\left\{{ }^{1} \mathrm{H}\right\}$ NMR spectrum of $\operatorname{Ir}\left(\mathrm{F}_{2} \text { ppy }\right)_{2}($ Fze $)(\mathbf{2 e})$, recorded at $151 \mathrm{MHz}$ in $\mathrm{CDCl}_{3}$. Peak positions are shown below the horizontal axis. 


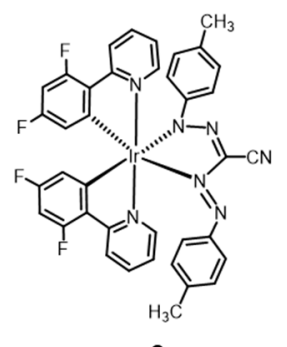

$2 \mathrm{e}$

${ }^{19} \mathrm{~F} \mathrm{NMR}$ in $\mathrm{CDCl}_{3}$

$470 \mathrm{MHz}$

\begin{tabular}{|c|c|c|c|c|}
\hline-70.0 & -80.0 & -90.0 & -100.0 & -110.0 \\
\hline
\end{tabular}

Figure S28. ${ }^{19} \mathrm{~F}$ NMR spectrum of $\operatorname{Ir}\left(\mathrm{F}_{2} \mathrm{ppy}\right)_{2}(\mathbf{F z e})(\mathbf{2 e})$, recorded at $470 \mathrm{MHz}$ in $\mathrm{CDCl}_{3}$. Peak positions are shown below the horizontal axis.

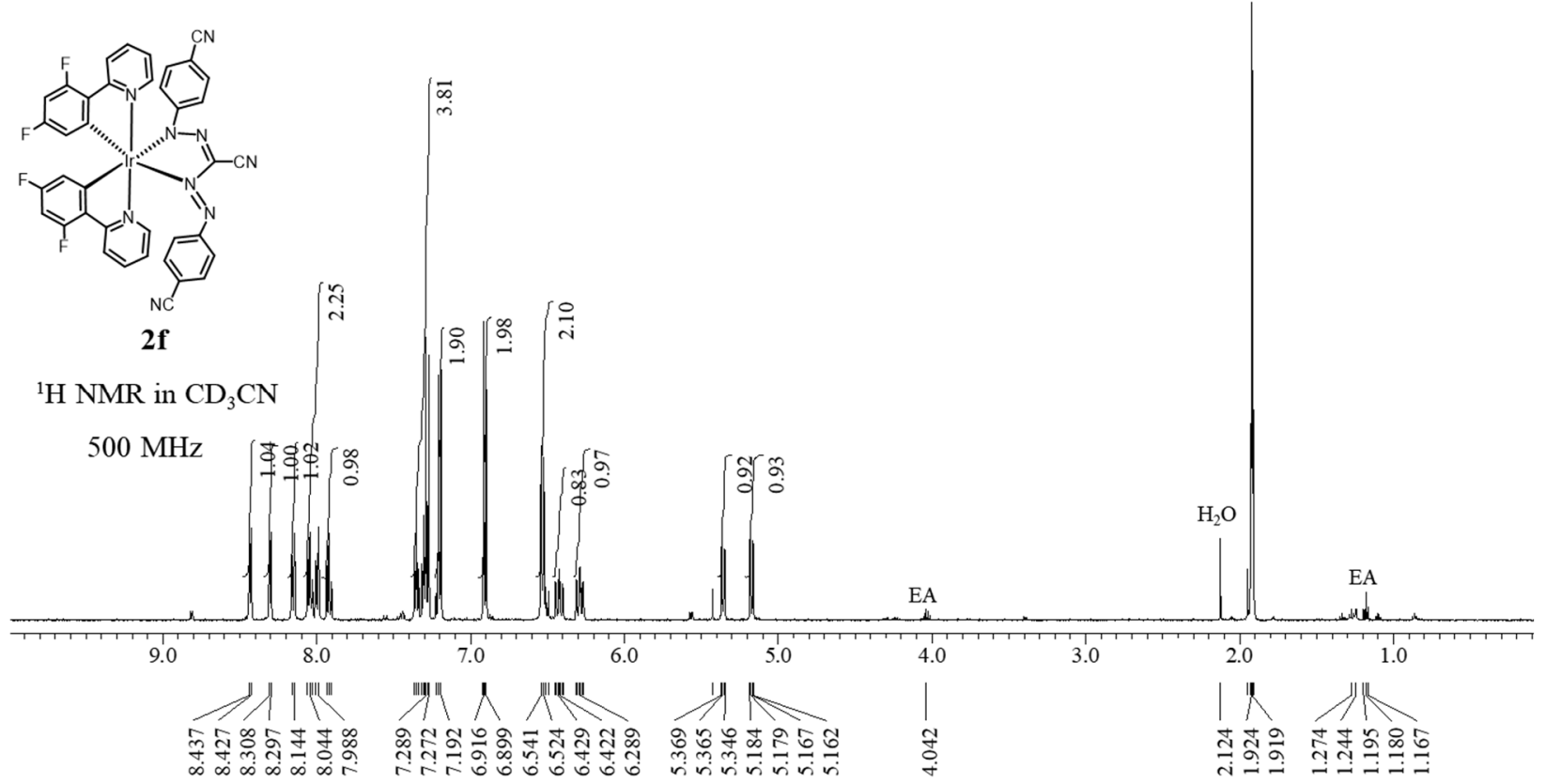

Figure S29. ${ }^{1} \mathrm{H}$ NMR spectrum of $\operatorname{Ir}\left(\mathrm{F}_{2} \mathrm{ppy}\right)_{2}(\mathbf{F z f})(\mathbf{2 f})$, recorded at $500 \mathrm{MHz}$ in $\mathrm{CD}_{3} \mathrm{CN}$. Peak positions are shown below the horizontal axis. Signals for residual ethyl acetate (EA) and $\mathrm{H}_{2} \mathrm{O}$ are marked. 


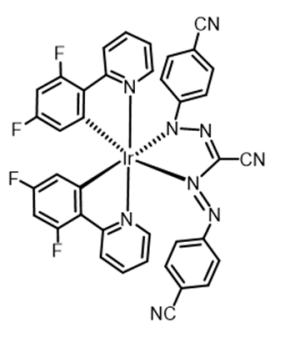

$2 f$

${ }^{13} \mathrm{C}\left\{{ }^{1} \mathrm{H}\right\} \mathrm{NMR}$ in $\mathrm{CD}_{3} \mathrm{CN}$

$151 \mathrm{MHz}$

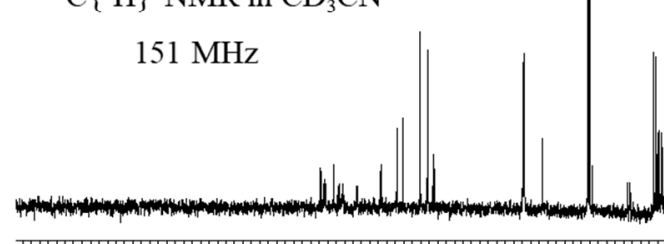

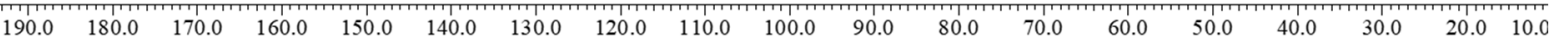

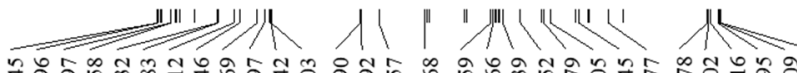

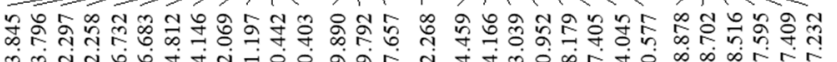

x : parts per Million: Carboñ

Figure S30. ${ }^{13} \mathrm{C}\left\{{ }^{1} \mathrm{H}\right\}$ NMR spectrum of $\operatorname{Ir}\left(\mathrm{F}_{2} \mathrm{ppy}\right)_{2}$ (Fzf) 2f, recorded at $151 \mathrm{MHz}$ in $\mathrm{CD}_{3} \mathrm{CN}$. Peak positions are shown below the horizontal axis.

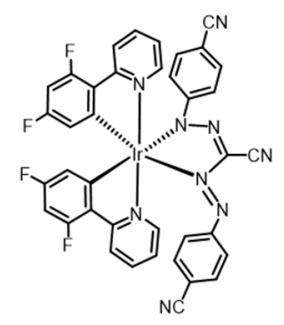

2f

${ }^{19} \mathrm{~F} \mathrm{NMR}$ in $\mathrm{CD}_{3} \mathrm{CN}$

$470 \mathrm{MHz}$

\begin{tabular}{|c|c|c|c|c|c|c|c|}
\hline-80.0 & -90.0 & -100.0 & -110.0 & -120.0 & -130.0 & -140.0 & -150.0 \\
\hline
\end{tabular}

Figure S31. ${ }^{19} \mathrm{~F}$ NMR spectrum of $\operatorname{Ir}\left(\mathrm{F}_{2} \mathrm{ppy}\right)_{2}($ Fzf $)(\mathbf{2 f})$, recorded at $470 \mathrm{MHz}$ in $\mathrm{CD}_{3} \mathrm{CN}$. Peak positions are shown below the horizontal axis. 


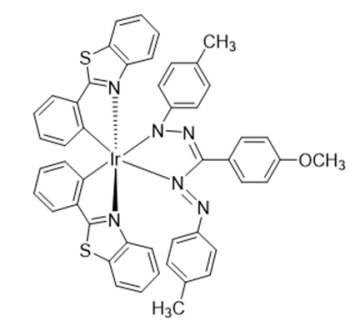

3a

${ }^{1} \mathrm{H}$ NMR in $\mathrm{CDCl}_{3}$

$500 \mathrm{MHz}$

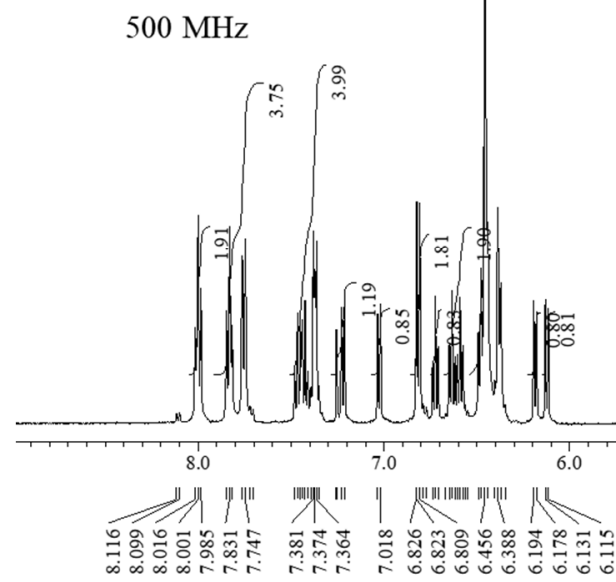

Figure S32. ${ }^{1} \mathrm{H}$ NMR spectrum of $\operatorname{Ir}(\mathrm{bt})_{2}$ (Fza) (3a), recorded at $500 \mathrm{MHz}$ in $\mathrm{CDCl}_{3}$. Peak positions are shown below the horizontal axis. Signals for residual water $\mathrm{H}_{2} \mathrm{O}$ and pentane are marked.

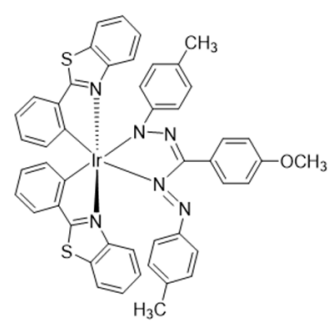

3a

${ }^{13} \mathrm{C}\left\{{ }^{1} \mathrm{H}\right\} \mathrm{NMR}$ in $\mathrm{CDCl}_{3}$ $101 \mathrm{MHz}$

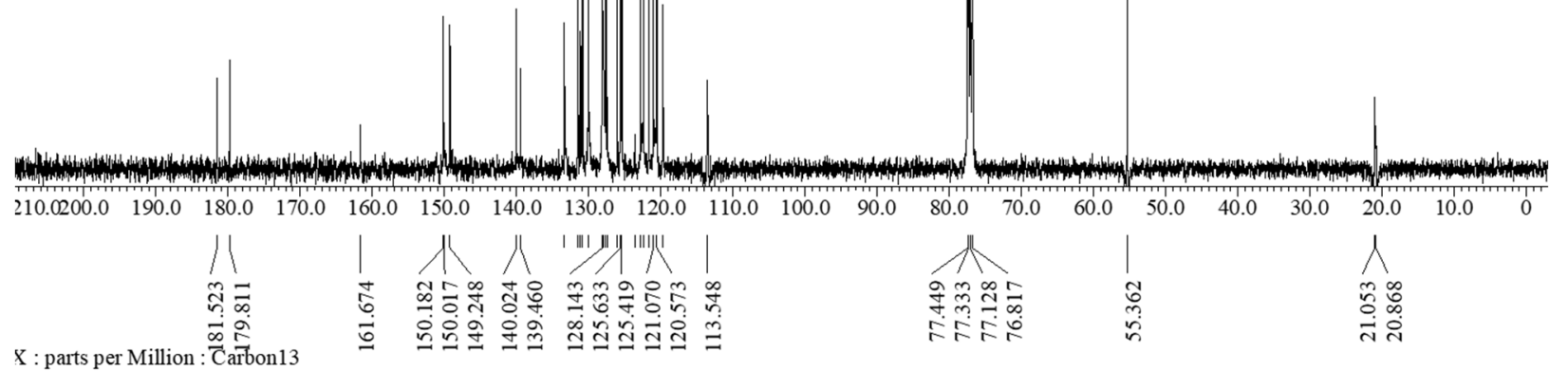

Figure S33. ${ }^{13} \mathrm{C}\left\{{ }^{1} \mathrm{H}\right\}$ NMR spectrum of $\operatorname{Ir}(\mathrm{bt})_{2}(\mathrm{Fza})(\mathbf{3 a})$, recorded at $101 \mathrm{MHz}$ in $\mathrm{CDCl}_{3}$. Peak positions are shown below the horizontal axis. 


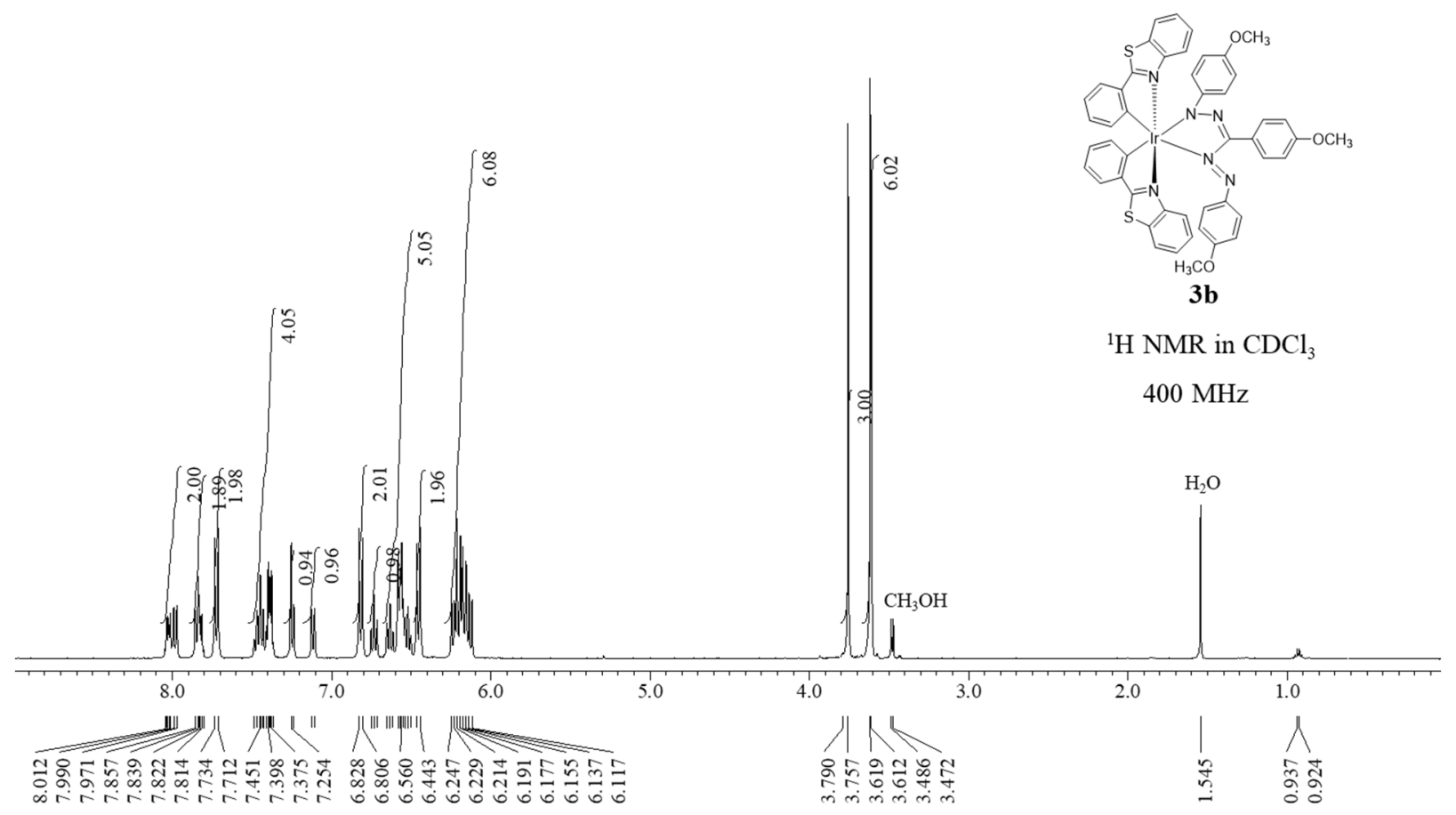

Figure S34. ${ }^{1} \mathrm{H}$ NMR spectrum of $\operatorname{Ir}(\mathrm{bt})_{2}(\mathbf{F z b})(\mathbf{3 b})$, recorded at $400 \mathrm{MHz}$ in $\mathrm{CDCl}_{3}$. Peak positions are shown below the horizontal axis. Signals for residual water $\mathrm{H}_{2} \mathrm{O}$ and methanol $\left(\mathrm{CH}_{3} \mathrm{OH}\right)$ are marked. Methanol was used as a recrystallizing solvent.

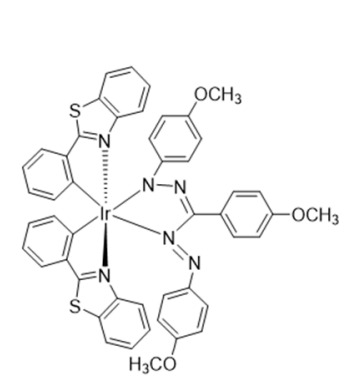

$3 \mathbf{b}$

${ }^{13} \mathrm{C}\left\{{ }^{1} \mathrm{H}\right\} \mathrm{NMR}$ in $\mathrm{CDCl}_{3}$

$151 \mathrm{MHz}$

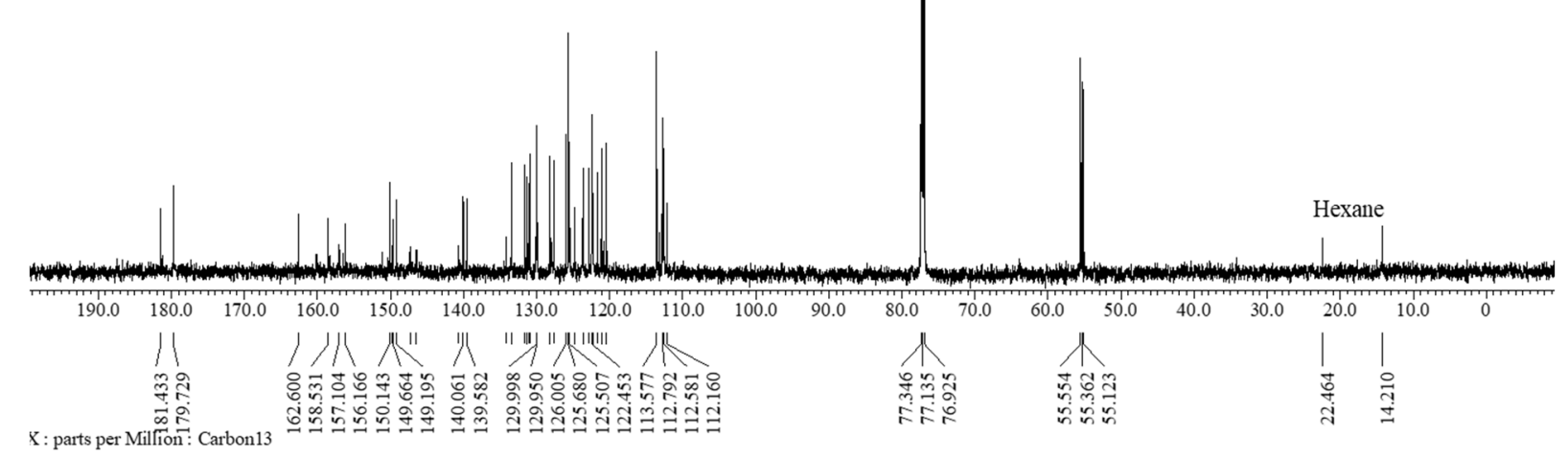

Figure S35. ${ }^{13} \mathrm{C}\left\{{ }^{1} \mathrm{H}\right\}$ NMR spectrum of $\operatorname{Ir}(\mathrm{bt})_{2}(\mathbf{F z b})(\mathbf{3 b})$, recorded at $151 \mathrm{MHz}$ in $\mathrm{CDCl}_{3}$. Peak positions are shown below the horizontal axis. Signals for hexane are marked. 


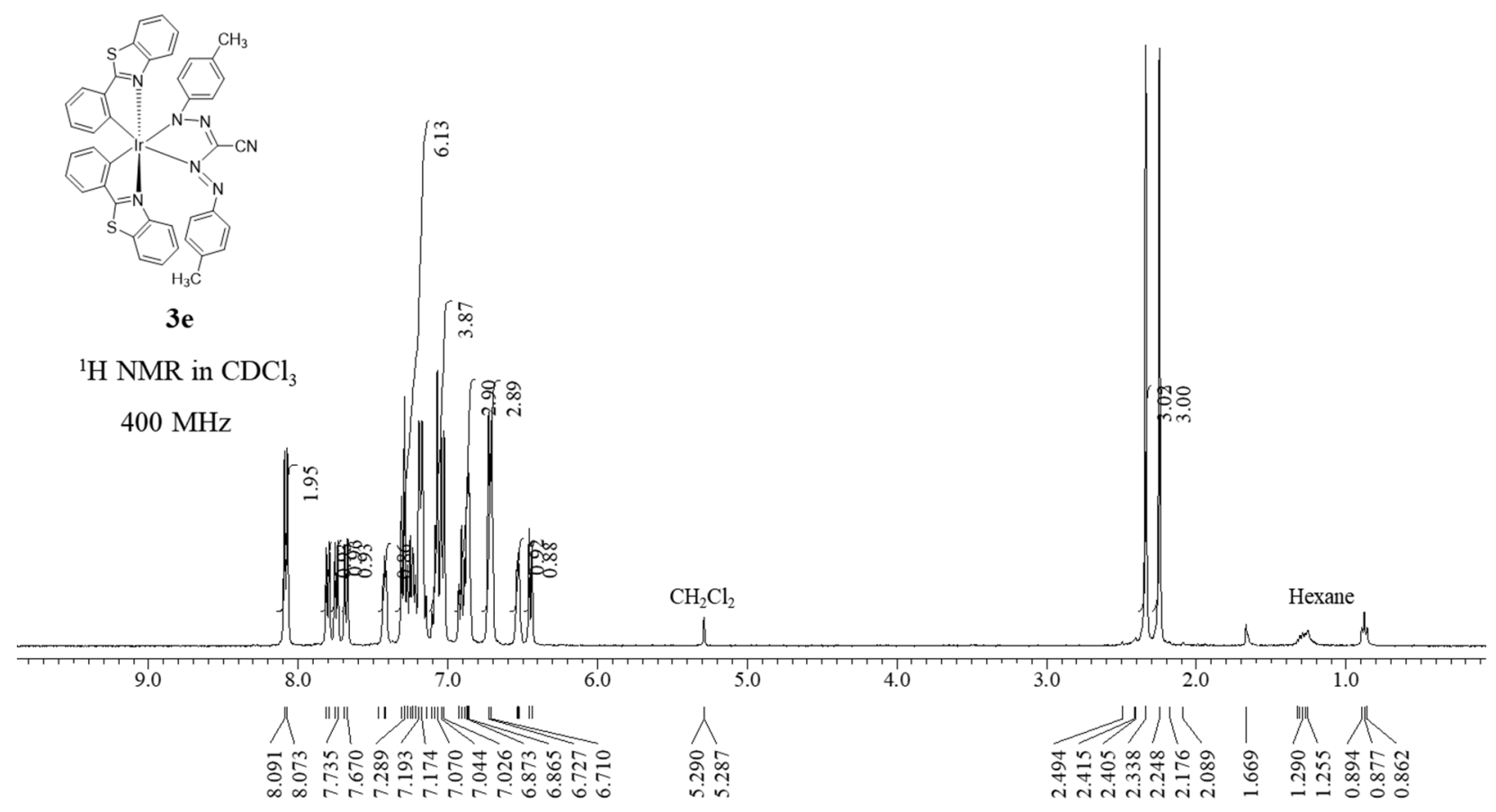

Figure S36. ${ }^{1} \mathrm{H}$ NMR spectrum of $\operatorname{Ir}(\mathrm{bt})_{2}(\mathrm{Fze})(\mathbf{3 e})$, recorded at $400 \mathrm{MHz}$ in $\mathrm{CDCl}_{3}$. Peak positions are shown below the horizontal axis. Signals for residual $\mathrm{CH}_{2} \mathrm{Cl}_{2}$ and hexane are marked.

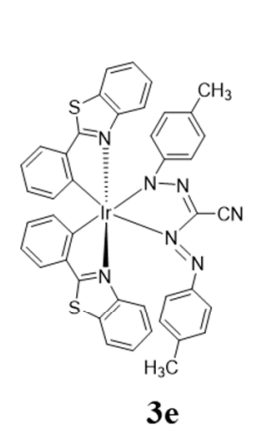

${ }^{13} \mathrm{C}\left\{{ }^{1} \mathrm{H}\right\} \mathrm{NMR}$ in $\mathrm{CDCl}_{3}$

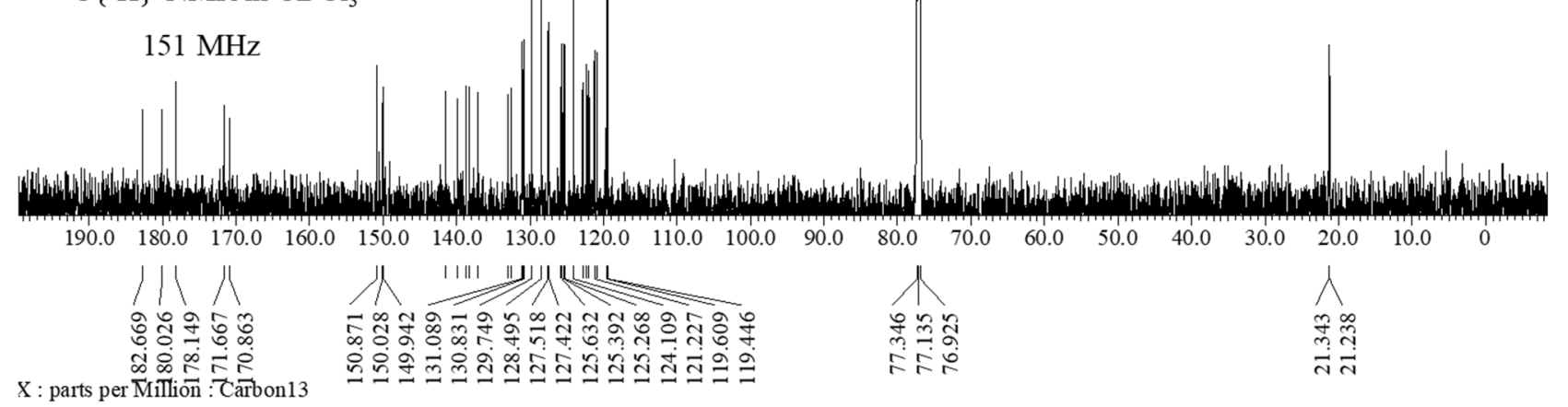

Figure S37. ${ }^{13} \mathrm{C}\left\{{ }^{1} \mathrm{H}\right\}$ NMR spectrum of $\operatorname{Ir}(\mathrm{bt})_{2}($ Fze $)(3 \mathbf{e})$, recorded at $151 \mathrm{MHz}$ in $\mathrm{CDCl}_{3}$. Peak positions are shown below the horizontal axis. 


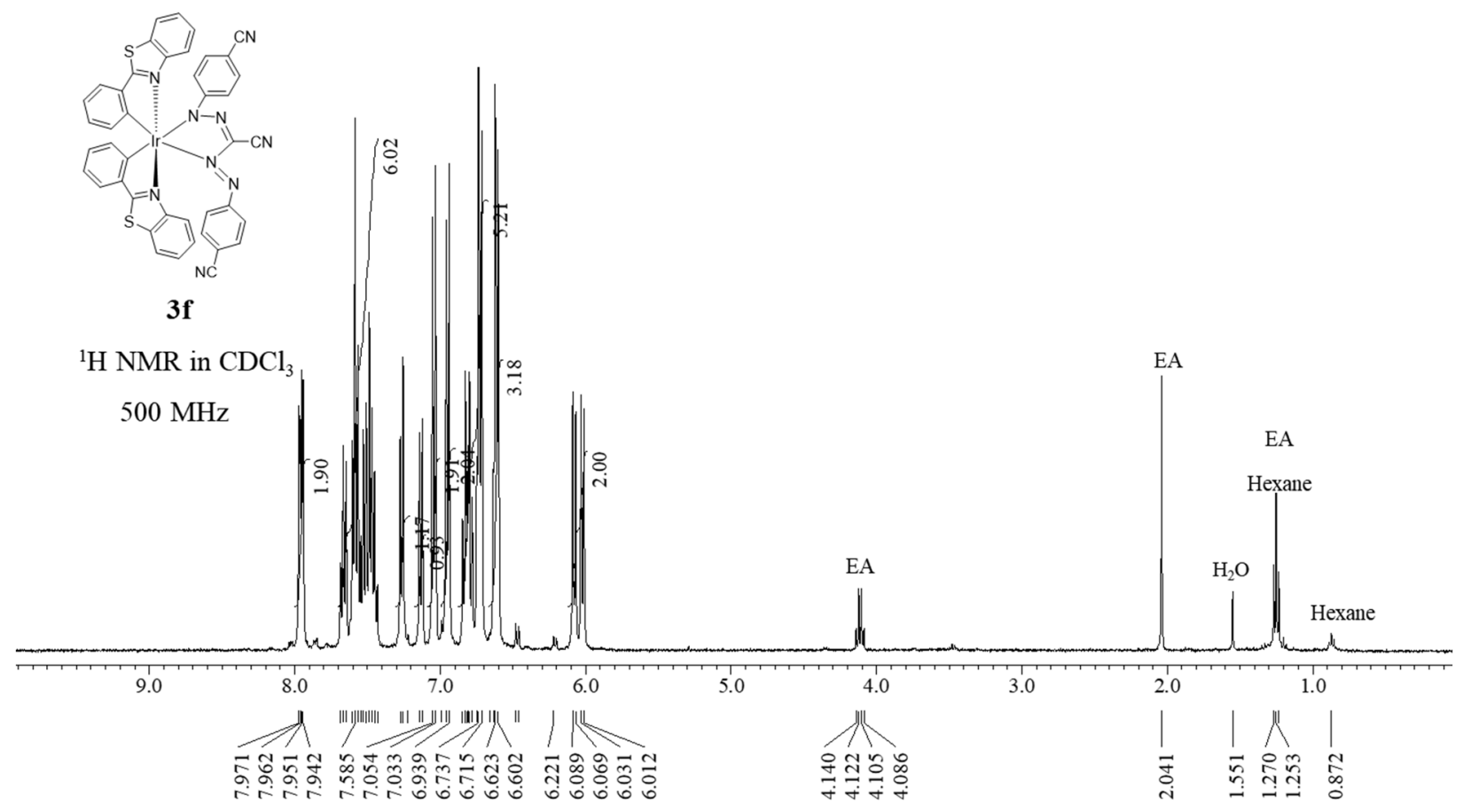

Figure S38. ${ }^{1} \mathrm{H}$ NMR spectrum of $\operatorname{Ir}(\mathrm{bt})_{2}(\mathbf{F z f})(\mathbf{3 f})$, recorded at $500 \mathrm{MHz}$ in $\mathrm{CDCl}_{3}$. Peak positions are shown below the horizontal axis. Signals for residual ethyl acetate $(E A), \mathrm{H}_{2} \mathrm{O}$, and hexane are marked. The solvents remained even after prolonged drying.

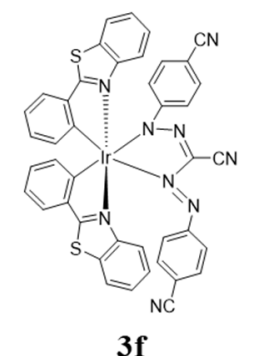

${ }^{13} \mathrm{C}\left\{{ }^{1} \mathrm{H}\right\} \mathrm{NMR}$ in $\mathrm{CDCl}_{3}$

$126 \mathrm{MHz}$

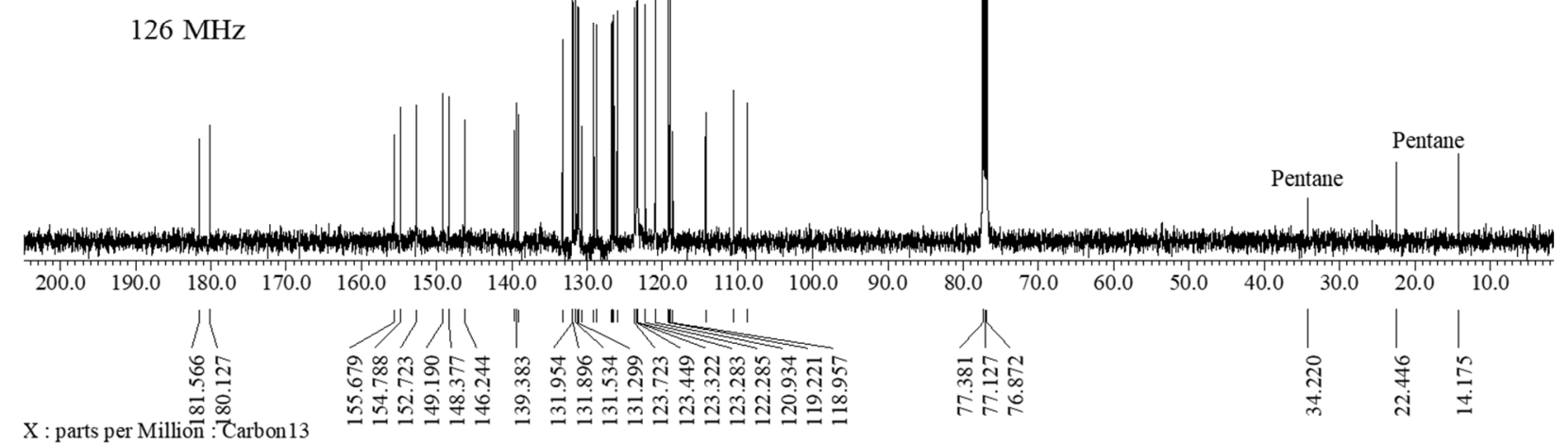

Figure S39. ${ }^{13} \mathrm{C}\left\{{ }^{1} \mathrm{H}\right\}$ NMR spectrum of $\operatorname{Ir}(\mathrm{bt})_{2}($ Fzf $)(\mathbf{3 f})$, recorded at $126 \mathrm{MHz}$ in $\mathrm{CDCl}_{3}$. Peak positions are shown below the horizontal axis. Signals for residual pentane are marked. 


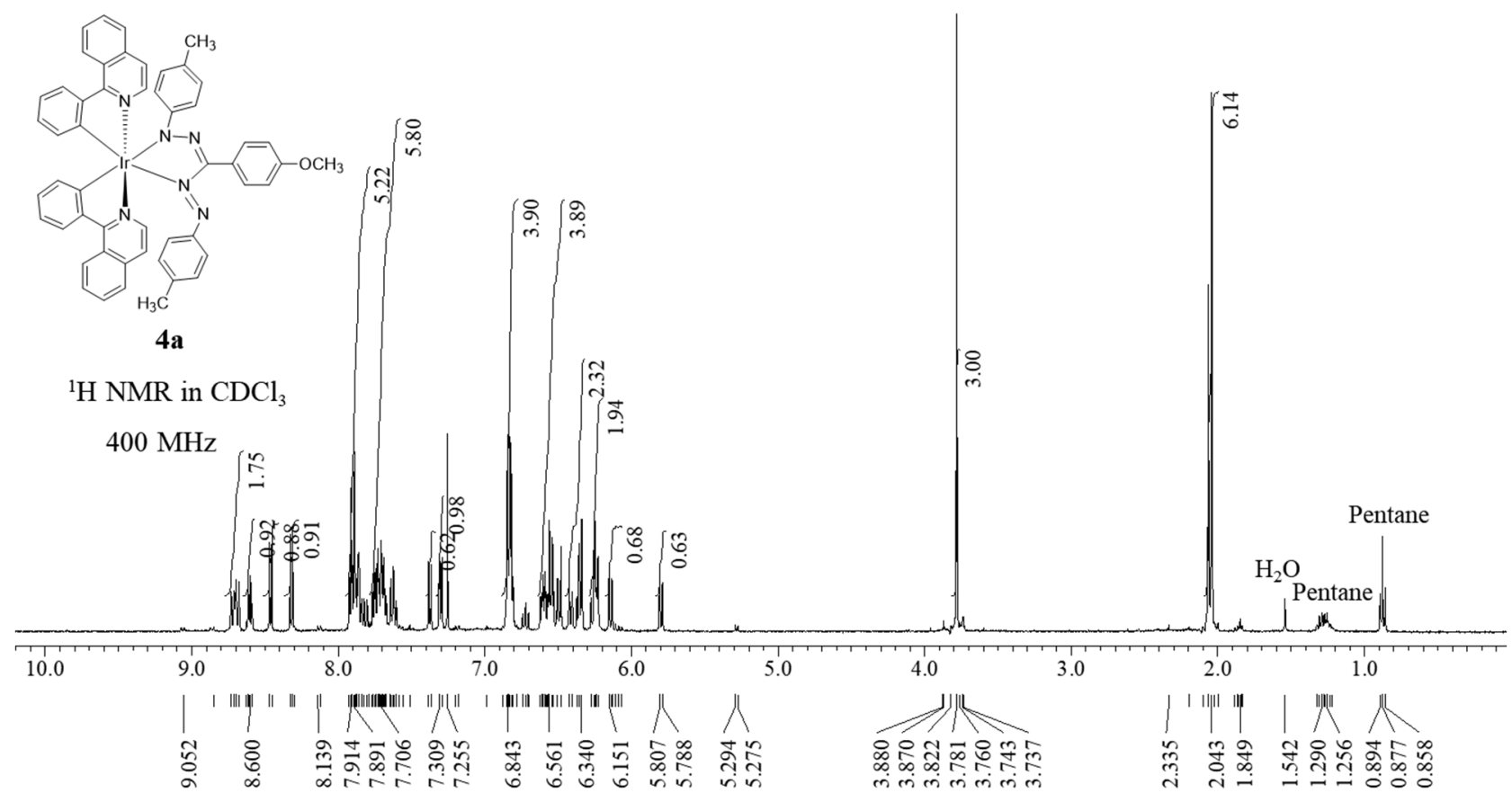

Figure S40. ${ }^{1} \mathrm{H}$ NMR spectrum of $\operatorname{Ir}\left(\right.$ piq) 2 (Fza) (4a), recorded at $400 \mathrm{MHz}$ in $\mathrm{CDCl}_{3}$. Peak positions are shown below the horizontal axis. Signals for residual $\mathrm{H}_{2} \mathrm{O}$ and pentane are marked.

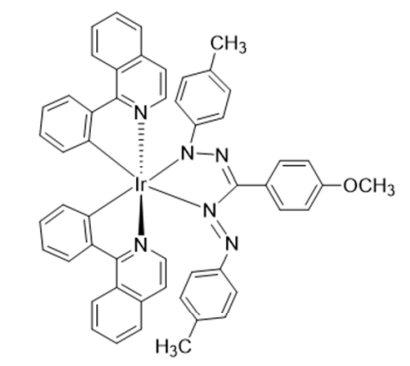

$4 \mathbf{a}$

${ }^{13} \mathrm{C}\left\{{ }^{1} \mathrm{H}\right\} \mathrm{NMR}$ in $\mathrm{CDCl}_{3}$

$151 \mathrm{MHz}$

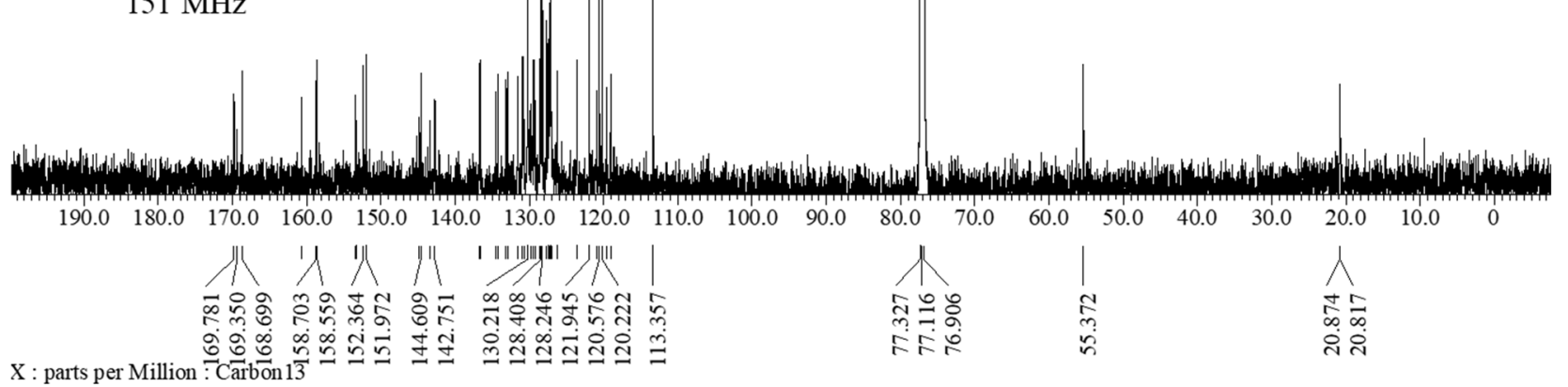

Figure S41. ${ }^{13} \mathrm{C}\left\{{ }^{1} \mathrm{H}\right\}$ NMR spectrum of $\operatorname{Ir}\left(\right.$ piq) 2 (Fza) (4a), recorded at $151 \mathrm{MHz}$ in $\mathrm{CDCl}_{3}$. Peak positions are shown below the horizontal axis. 


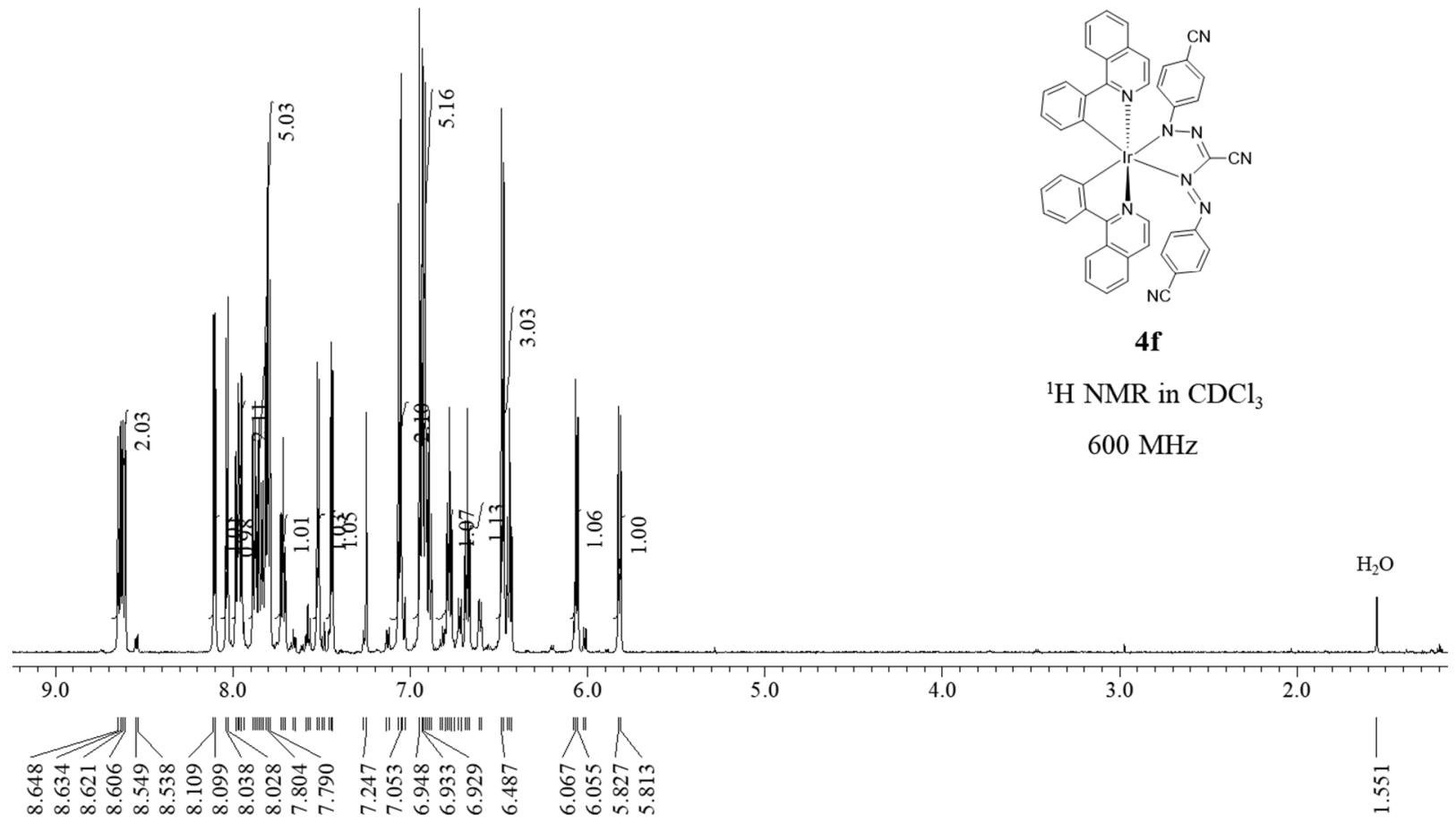

Figure S42. ${ }^{1} \mathrm{H}$ NMR spectrum of $\operatorname{Ir}\left(\right.$ piq) 2 (Fzf) (4f), recorded at $600 \mathrm{MHz}$ in $\mathrm{CDCl}_{3}$. Peak positions are shown below the horizontal axis. Signal for residual water $\mathrm{H}_{2} \mathrm{O}$ is marked.

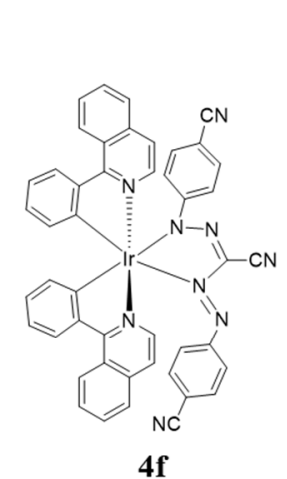

${ }^{13} \mathrm{C}\left\{{ }^{1} \mathrm{H}\right\} \mathrm{NMR}$ in $\mathrm{CDCl}_{3}$

$151 \mathrm{MHz}$

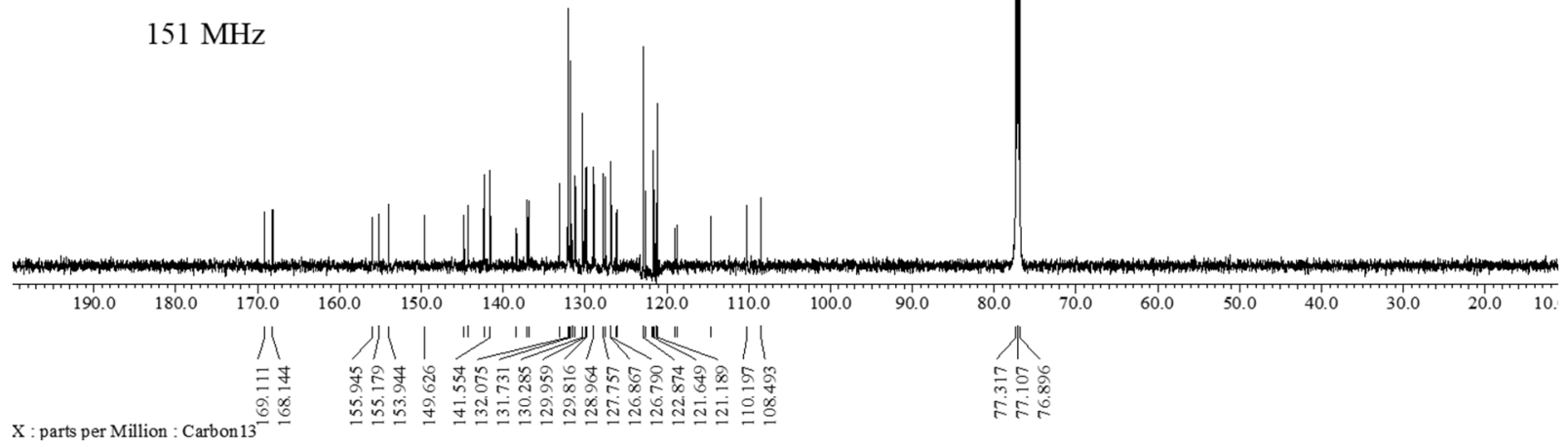

Figure S43. ${ }^{13} \mathrm{C}\left\{{ }^{1} \mathrm{H}\right\}$ NMR spectrum of $\operatorname{Ir}(\text { piq) })_{2}($ Fzf $)(\mathbf{4 f})$, recorded at $151 \mathrm{MHz}$ in $\mathrm{CDCl}_{3}$. Peak positions are shown below the horizontal axis. 


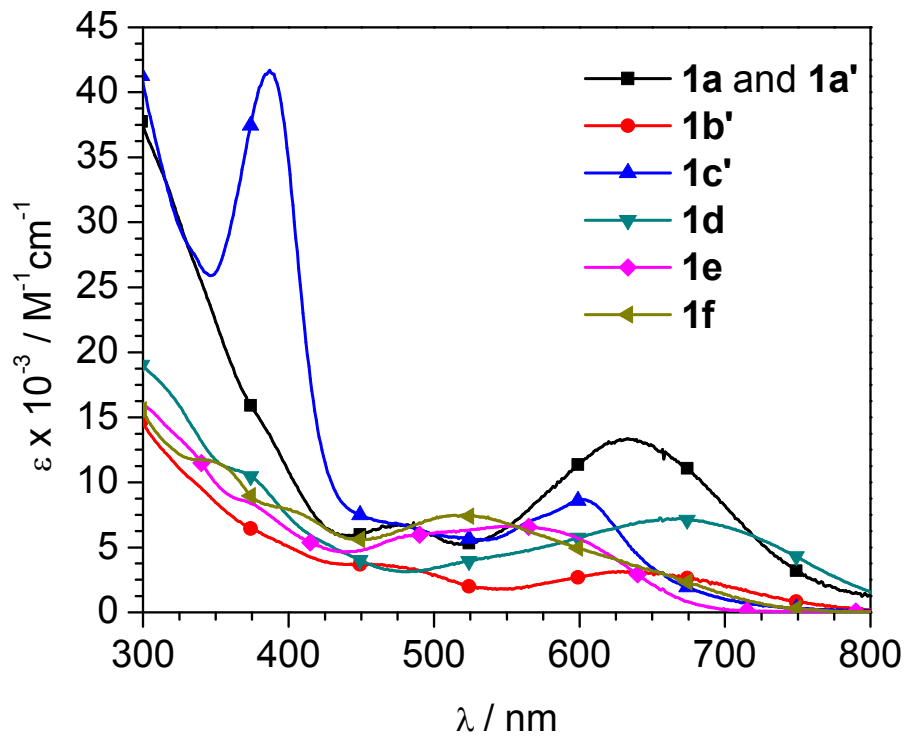

Figure S44. Overlaid electronic absorption spectra of 1a-1f. Spectra were recorded in tetrahydrofuran (THF) in room temperature.

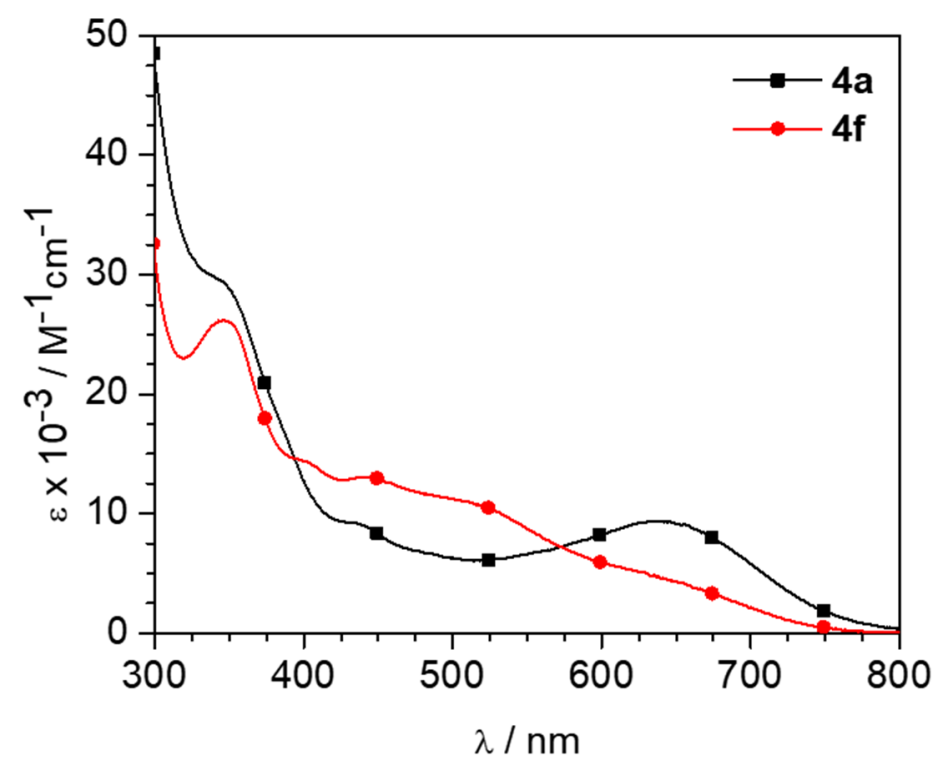

Figure S45. Overlaid electronic absorption spectra of $4 \mathbf{a}$ and $4 \mathbf{f}$. Spectra were recorded in tetrahydrofuran (THF) in room temperature. 

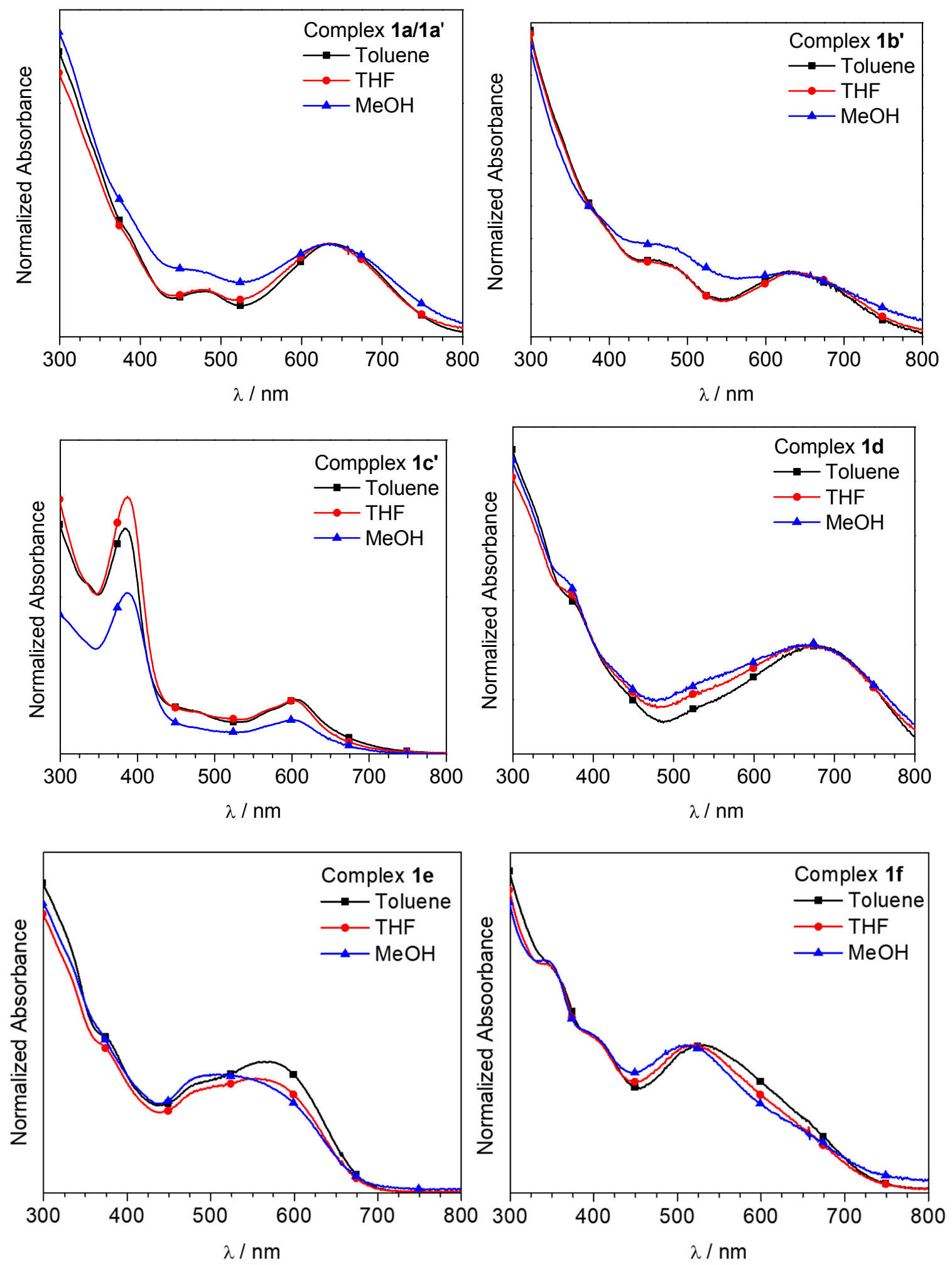

Figure S46. Electronic absorption spectra of complex 1a-f, recorded in toluene, tetrahydrofuran (THF), and $\mathrm{MeOH}$ at room temperature. The spectra are normalized to the low-energy absorption maximum. 

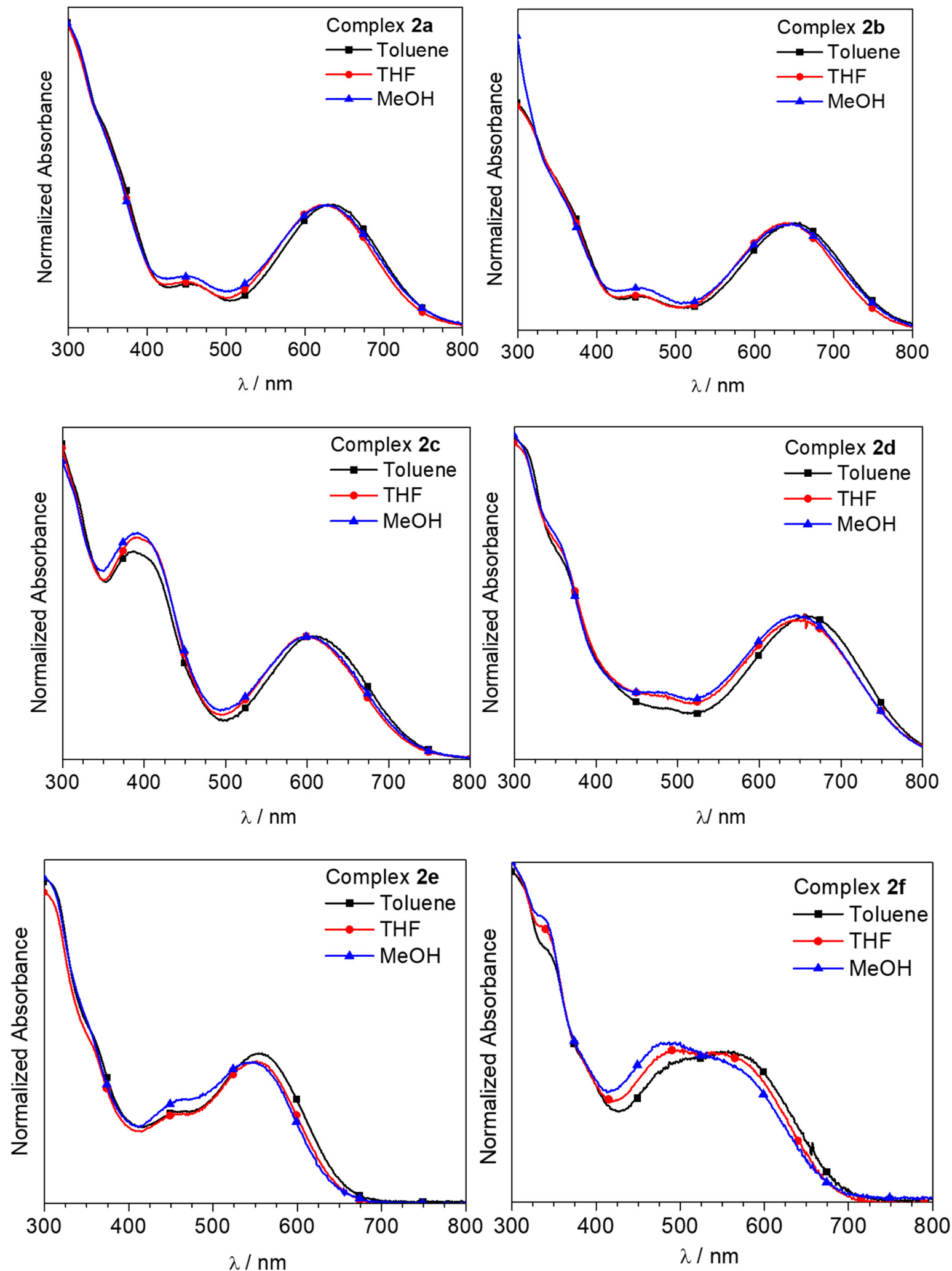

Figure S47. Electronic absorption spectra of complex 2a-f, recorded in toluene, tetrahydrofuran (THF), and $\mathrm{MeOH}$ at room temperature. The spectra are normalized to the low-energy absorption maximum. 

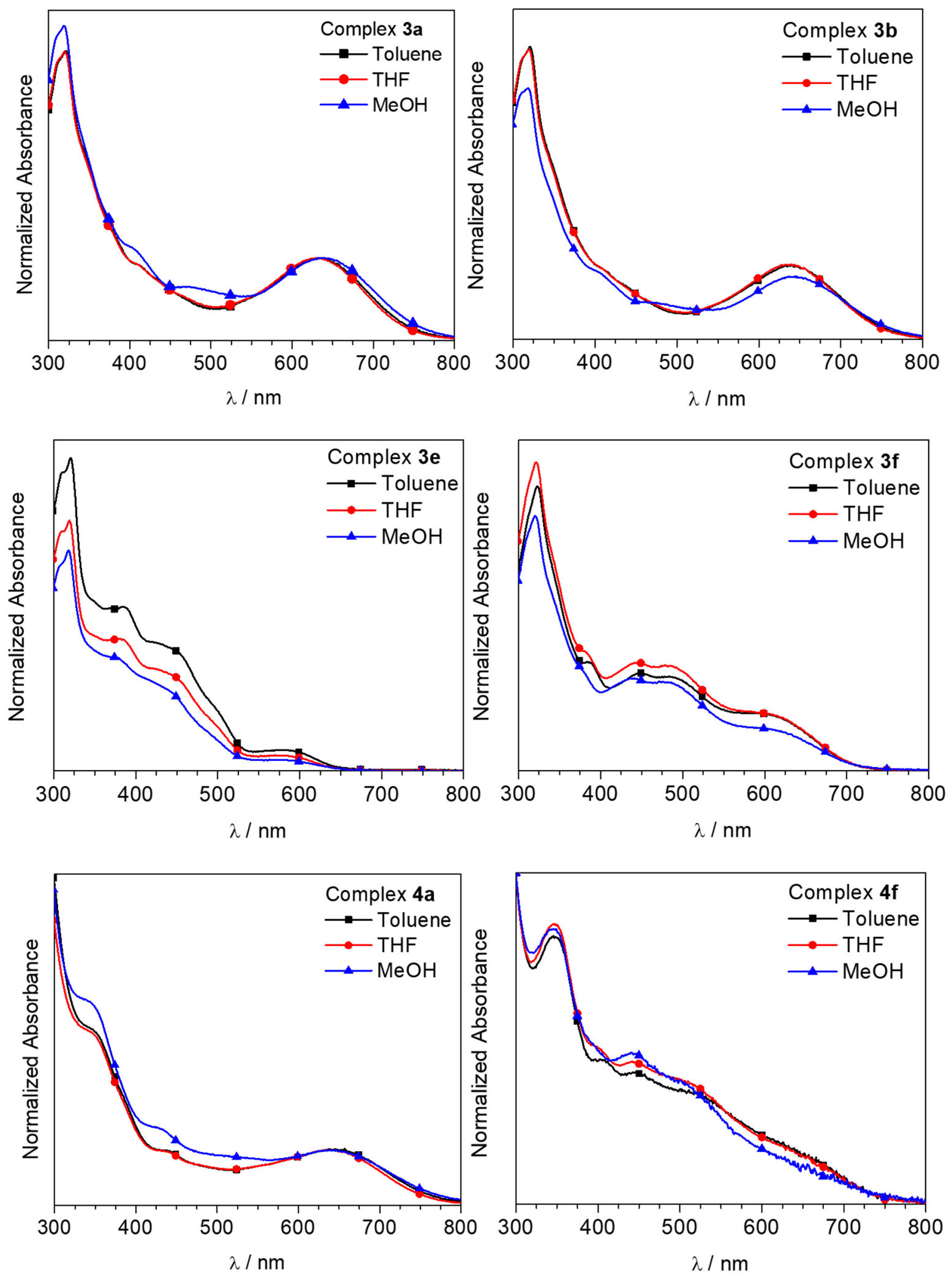

Figure S48. Electronic absorption spectra of complex 3a-b, 3e-f, $4 \mathbf{a}$ and $\mathbf{4 f}$, recorded in toluene, tetrahydrofuran (THF), and $\mathrm{MeOH}$ at room temperature. The spectra are normalized to the low-energy absorption maximum. 
Table S4. Summary of UV-vis absorption maxima for spectra recorded in tetrahydrofuran (THF), toluene, and $\mathrm{MeOH}$.

\begin{tabular}{|c|c|c|c|}
\hline & \multicolumn{3}{|c|}{$\lambda(\mathrm{nm})$} \\
\hline & THF & Toluene & $\mathrm{MeOH}$ \\
\hline $\operatorname{Ir}(\text { ppy })_{2}(\mathbf{F z a})\left(\mathbf{1 a} / \mathbf{1} \mathbf{a}^{\prime}\right)$ & $265,480,633$ & 478,635 & $262,472,631$ \\
\hline $\operatorname{Ir}(\mathrm{ppy})_{2}(\mathbf{F z b})\left(\mathbf{1} \mathbf{b}^{\prime}\right)$ & $261,463,630$ & 468,633 & $258,459,630$ \\
\hline $\operatorname{Ir}(\mathrm{ppy})_{2}(\mathbf{F z c})\left(\mathbf{1} \mathbf{c}^{\prime}\right)$ & $264,387,602$ & 385,605 & $260,387,599$ \\
\hline $\operatorname{Ir}(\text { ppy })_{2}$ (Fzd) (1d) & $270,374^{\mathrm{a}}, 673$ & $271,374^{\mathrm{a}}, 677$ & $269,370^{\mathrm{a}}, 674$ \\
\hline $\operatorname{Ir}(\text { ppy })_{2}(\mathbf{F z e})(\mathbf{1 e})$ & $260,380^{\mathrm{a}}, 476,554$ & $380^{\mathrm{a}}, 478,565$ & $378^{a}, 477,553$ \\
\hline $\operatorname{Ir}(\mathrm{ppy})_{2}(\mathbf{F z f})(\mathbf{1 f})$ & $258,342,401^{\mathrm{a}}, 520$ & $349,402^{\mathrm{a}}, 527$ & $258,341,400^{\mathrm{a}}, 512$ \\
\hline $\operatorname{Ir}\left(\mathrm{F}_{2} \text { ppy }\right)_{2}(\mathbf{F z a})(\mathbf{2 a})$ & $250,347^{\mathrm{a}}, 445,628$ & $346^{\mathrm{a}}, 452,632$ & $249,344^{\mathrm{a}}, 453,628$ \\
\hline $\operatorname{Ir}\left(\mathrm{F}_{2} \mathrm{ppy}\right)_{2}(\mathbf{F z b})(\mathbf{2 b})$ & $252,454,639$ & 452,651 & $260,451,646$ \\
\hline $\operatorname{Ir}\left(\mathrm{F}_{2} \mathrm{ppy}\right)_{2}(\mathbf{F z c})(\mathbf{2 c})$ & $251,390,601$ & 387,606 & 390,605 \\
\hline $\operatorname{Ir}\left(\mathrm{F}_{2} \mathrm{ppy}\right)_{2}(\mathbf{F z d})(\mathbf{2 d})$ & $260^{\mathrm{a}}, 313^{\mathrm{a}}, 360^{\mathrm{a}}, 655$ & $315^{\mathrm{a}}, 361^{\mathrm{a}}, 656$ & $312^{\mathrm{a}}, 357^{\mathrm{a}}, 640$ \\
\hline $\operatorname{Ir}\left(\mathrm{F}_{2} \mathrm{ppy}\right)_{2}(\mathbf{F z e})(\mathbf{2 e})$ & $250,300,454^{\mathrm{a}}, 551$ & $302,455^{\mathrm{a}}, 554$ & $300,454^{\mathrm{a}}, 547$ \\
\hline $\operatorname{Ir}\left(\mathrm{F}_{2} \mathrm{ppy}\right)_{2}(\mathbf{F z f})(\mathbf{2 f})$ & $261,353^{\mathrm{a}}, 532$ & $354^{\mathrm{a}}, 545$ & $261,347^{\mathrm{a}}, 524$ \\
\hline $\operatorname{Ir}(\mathrm{bt})_{2}$ (Fza) (3a) & $320,410^{\mathrm{a}}, 630$ & $319,412^{\mathrm{a}}, 636$ & $318,403^{\mathrm{a}}, 476^{\mathrm{a}}, 639$ \\
\hline $\operatorname{Ir}(\mathrm{bt})_{2}(\mathbf{F z b})(\mathbf{3 b})$ & $262,319,635$ & 320,637 & $261,307,636$ \\
\hline $\operatorname{Ir}(\mathrm{bt})_{2}$ (Fze) (3e) & $263,319,382^{\mathrm{a}}, 443^{\mathrm{a}}, 578$ & $321,383^{\mathrm{a}}, 451^{\mathrm{a}}, 580$ & $318,378,438^{\mathrm{a}}, 572$ \\
\hline $\operatorname{Ir}(\mathrm{bt})_{2}(\mathbf{F z f})(\mathbf{3 f})$ & $266,321,384^{\mathrm{a}}, 443,596$ & $323,384^{\mathrm{a}}, 450,597$ & $320,378^{\mathrm{a}}, 439,595$ \\
\hline $\operatorname{Ir}(\text { piq) })_{2}(\mathbf{F z a})(\mathbf{4 a})$ & $293,349^{\mathrm{a}}, 435^{\mathrm{a}}, 638$ & $293,348^{\mathrm{a}}, 437^{\mathrm{a}}, 637$ & $288,344^{\mathrm{a}}, 431^{\mathrm{a}}, 637$ \\
\hline $\operatorname{Ir}(\text { piq })_{2}(\mathbf{F z f})(\mathbf{4 f})$ & $285,343,403,443,525^{\mathrm{a}}$ & $346,406,446,526^{\mathrm{a}}$ & $283,343,436,522^{a}$ \\
\hline
\end{tabular}




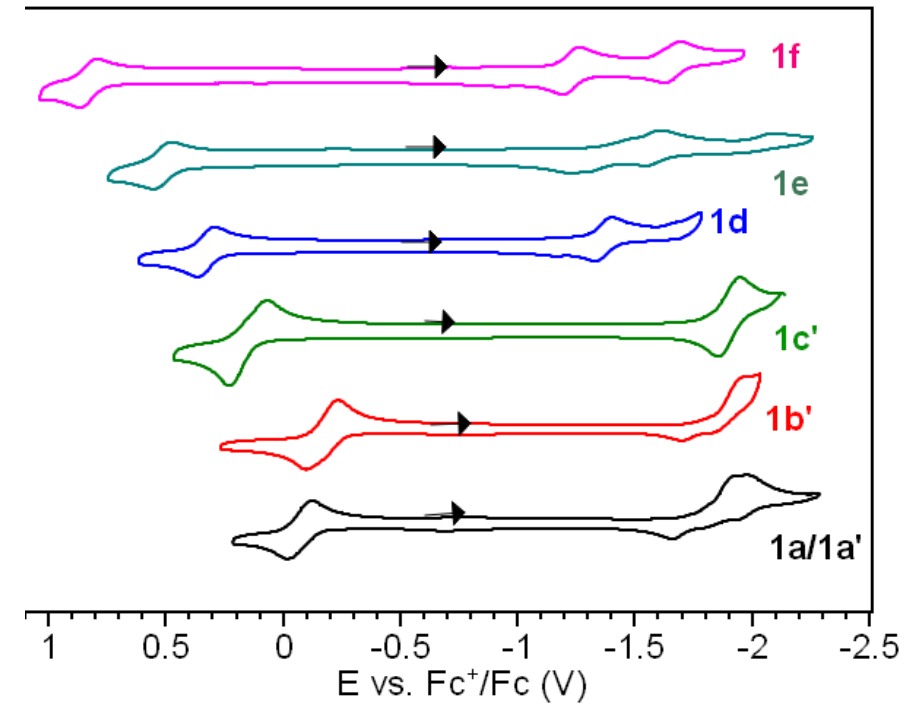

Figure S49. Overlaid cyclic voltammograms of complexes $\mathbf{1 a}-\mathbf{1 f}$. CVs were recorded in $\mathrm{CH}_{2} \mathrm{Cl}_{2}$ with $0.1 \mathrm{M}$ $\mathrm{NBu}_{4} \mathrm{PF}_{6}$ supporting electrolyte, using a glassy carbon working electrode and a scan rate of $0.1 \mathrm{~V} / \mathrm{s}$. The arrows indicate the scan direction. Concentrations were not carefully controlled, which results in the different current values for these plots.

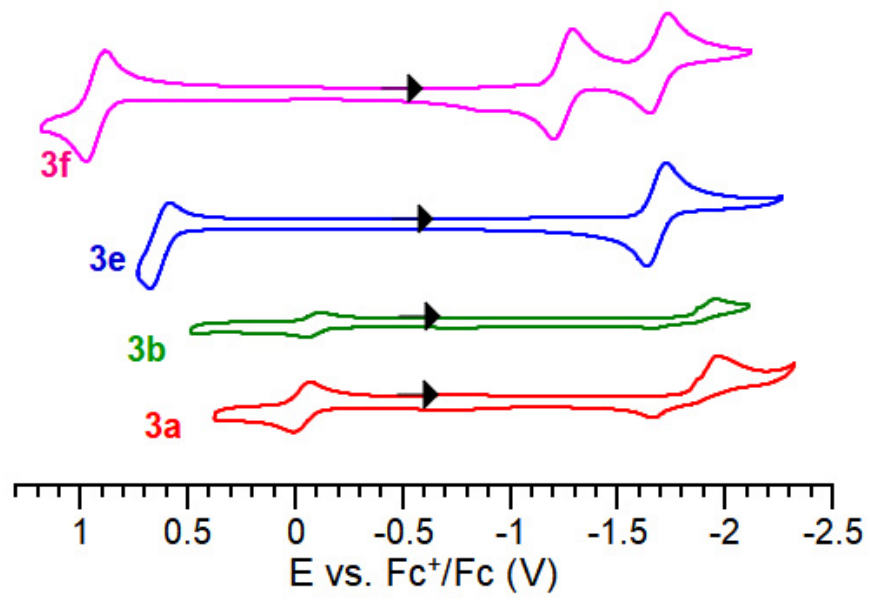

Figure S50. Overlaid cyclic voltammograms of complexes $\mathbf{3 a}, \mathbf{3 b}, \mathbf{3 e}$, and $\mathbf{3 f}$. $\mathrm{CVs}$ were recorded in $\mathrm{CH}_{2} \mathrm{Cl}_{2}$ with $0.1 \mathrm{M} \mathrm{NBu}_{4} \mathrm{PF}_{6}$ supporting electrolyte, using a glassy carbon working electrode and a scan rate of 0.1 $\mathrm{V} / \mathrm{s}$. The arrows indicate the scan direction. Concentrations were not carefully controlled, which results in the different current values for these plots. 


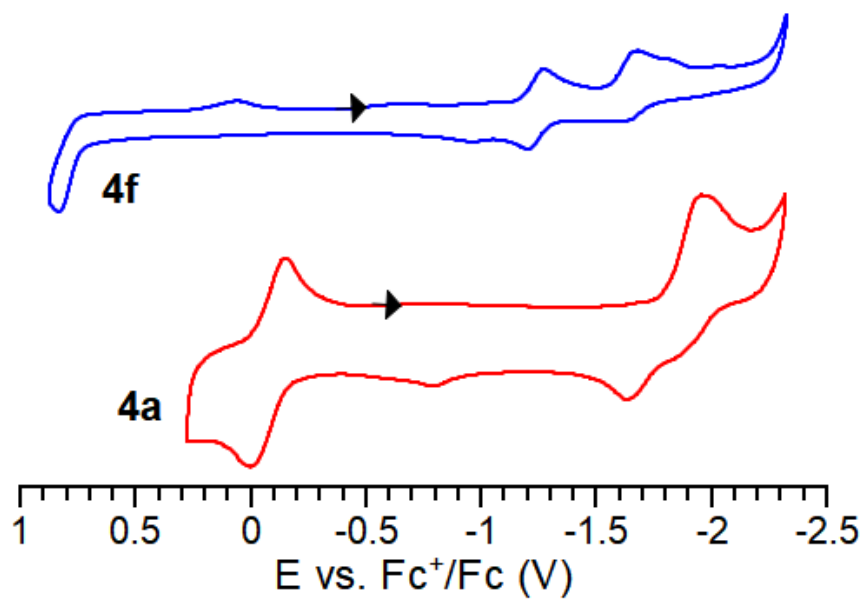

Figure S51. Overlaid cyclic voltammograms of complexes $4 \mathbf{a}$ and 4 f. $\mathrm{CVs}$ were recorded in $\mathrm{CH}_{2} \mathrm{Cl}_{2}$ with $0.1 \mathrm{M} \mathrm{NBu}_{4} \mathrm{PF}_{6}$ supporting electrolyte, using a glassy carbon working electrode and a scan rate of $0.1 \mathrm{~V} / \mathrm{s}$. The arrows indicate the scan direction. Concentrations were not carefully controlled, which results in the different current values for these plots. 
